\title{
Metal Chloride Hydrates as Lewis Acid Catalysts in Multicomponent Synthesis of 2,4,5-Triarylimidazoles or 2,4,5-Triaryloxazoles
}

\author{
Marcelo V. Marques, ${ }^{a, b}$ Marcelo M. Ruthner, ${ }^{c}$ Luiz A. M. Fontoura ${ }^{*, a, c}$ and \\ Dennis Russowsky*,b
}

${ }^{a}$ Departamento de Engenharia de Processos, Fundação de Ciência e Tecnologia, 94930-230 Cachoeirinha-RS, Brazil

${ }^{b}$ Laboratório de Sínteses Orgânicas, Instituto de Química, Universidade Federal do Rio Grande do Sul, 91501-970 Porto Alegre-RS, Brazil

${ }^{c}$ Curso de Química, Universidade Luterana do Brasil, 92452-900 Canoas-RS, Brazil

Uma série de nove hidratos de cloretos metálicos $\left(\mathrm{ZnCl}_{2} \cdot 2 \mathrm{H}_{2} \mathrm{O}, \mathrm{SnCl}_{2} \cdot 2 \mathrm{H}_{2} \mathrm{O}, \mathrm{CdCl}_{2} \cdot 2 \mathrm{H}_{2} \mathrm{O}\right.$, $\mathrm{MnCl}_{2} \cdot 4 \mathrm{H}_{2} \mathrm{O}, \mathrm{CoCl}_{2} \cdot 6 \mathrm{H}_{2} \mathrm{O}, \mathrm{SrCl}_{2} \cdot 6 \mathrm{H}_{2} \mathrm{O}, \mathrm{NiCl}_{2} \cdot 6 \mathrm{H}_{2} \mathrm{O}, \mathrm{CrCl}_{3} \cdot 6 \mathrm{H}_{2} \mathrm{O}$ e CeCl $3 \cdot 7 \mathrm{H}_{2} \mathrm{O}$ ) foi investigada como catalisadores ácidos de Lewis brandos e baratos na síntese multicomponente de triarilimidazóis. O melhor catalisador para as reações com benzila foi o $\mathrm{SnCl}_{2} \cdot 2 \mathrm{H}_{2} \mathrm{O}$, enquanto que para as reações com benzoína, o $\mathrm{CeCl}_{3} \cdot 7 \mathrm{H}_{2} \mathrm{O}$ foi mais eficiente. Todas as reações foram efetuadas em EtOH como solvente. Estes catalisadores também foram empregados igualmente com sucesso na síntese de triariloxazóis.

A series of nine metal chloride hydrates $\left(\mathrm{ZnCl}_{2} \cdot 2 \mathrm{H}_{2} \mathrm{O}, \mathrm{SnCl}_{2} \cdot 2 \mathrm{H}_{2} \mathrm{O}, \mathrm{CdCl}_{2} \cdot 2 \mathrm{H}_{2} \mathrm{O}, \mathrm{MnCl}_{2} \cdot 4 \mathrm{H}_{2} \mathrm{O}\right.$, $\mathrm{CoCl}_{2} \cdot 6 \mathrm{H}_{2} \mathrm{O}, \mathrm{SrCl}_{2} \cdot 6 \mathrm{H}_{2} \mathrm{O}, \mathrm{NiCl}_{2} \cdot 6 \mathrm{H}_{2} \mathrm{O}, \mathrm{CrCl}_{3} \cdot 6 \mathrm{H}_{2} \mathrm{O}$ and $\mathrm{CeCl}_{3} \cdot 7 \mathrm{H}_{2} \mathrm{O}$ ) was investigated as mild and inexpensive Lewis acid catalysts to promote the multicomponent synthesis of triarylimidazoles. Reactions starting from benzil showed the best results when $\mathrm{SnCl}_{2} \cdot 2 \mathrm{H}_{2} \mathrm{O}$ was used, while for benzoin as the starting material, $\mathrm{CeCl}_{3} \cdot 7 \mathrm{H}_{2} \mathrm{O}$ was more efficient. All reactions were performed in $\mathrm{EtOH}$ as solvent. These catalysts were also successfully employed in the synthesis of triaryloxazoles.

Keywords: triarylimidazoles, triaryloxazoles, multicomponent reaction, metal halide hydrates, Lewis acids, Radziszewski reaction, benzil, benzoin

\section{Introduction}

Imidazole is a five-membered ring heteroaromatic compound with two nitrogen atoms at 1 and 3 positions. ${ }^{1}$ This type of compound is known to exhibit a broad range of pharmaceutical and industrial applications. For instance, the imidazole core unity is present in many compounds with pronounced biologic activities such as angiotensin inhibitors, ${ }^{2}$ anti-inflammatory, ${ }^{3}$ glucagon antagonist, ${ }^{4}$ antiviral, ${ }^{5}$ antimicrobial, ${ }^{6}$ fungicidal ${ }^{7}$ and high cytotoxicity, which has indicated them as new candidates in cancer therapy. ${ }^{8}$

A particular class of triarylimidazoles, the pyridinyl arylimidazoles 1, 2 and 3 have been recognized as a potent p38 mitogen-activated protein (MAP) kinase inhibitors and emerged as possible therapeutic drugs in

*e-mail: dennis@iq.ufrgs.br the treatment of various diseases such as cancer and as anti-inflammatory agent, combating the associated pain with osteoarthritis (Figure 1). ${ }^{9}$ Beyond the pharmacological applications, arylimidazoles have been used in the industry as chemiluminescent ${ }^{10}$ and chromotropic materials ${ }^{11}$ due to their optic and electronic properties. ${ }^{12}$

The synthesis of triarylimidazoles from the threecomponent reaction of 1,2-dicarbonyl compounds, aldehyde and ammonia was independently discovered by Japp and Robinson ${ }^{13}$ in 1882 and Radziszewski. ${ }^{14}$ However, long periods of time and harsh conditions were frequently associated with low yields of production. Davidson et al. ${ }^{15}$ showed to be possible to reduce the reaction times using acetic acid as solvent and ammonium acetate instead of ammonia. This last protocol became usual and default procedure for the synthesis of triarylimidazoles.

Recently, Kamijo and Yamamoto ${ }^{16}$ have reviewed the progress on the synthesis of imidazoles through catalyzed 
<smiles>CNCCOc1ccc(-c2nc(-c3ccncc3)c(-c3ccc4c(c3)CCC4=N)[nH]2)cc1</smiles>

1 - SB-590885

Oncogenic B-Raf protein kinase inhibitor

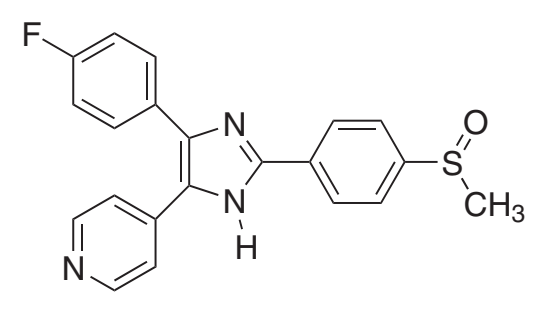

2 - SB-203580

Anti-inflammatory<smiles>NC(=O)c1ccc(-c2nc(-c3ccc4c(c3)OCO4)c(-c3ccncc3)[nH]2)cc1</smiles>

3 - SB-431542

Brain cancer therapy

Figure 1. Structures of some biologically active pyridinyl arylimmidazoles.

process. Besides other methods using Brønsted catalysis of $p$-toluenesulfonic acid ( $p$-TSA), ${ }^{17}$ heteropolyacids, ${ }^{18}$ oxalic acid ${ }^{19}$ and phosphomolybdic acid ${ }^{20}$ were developed. Heterogeneous catalysts based on silica-supported Brønsted or Lewis acids, such as $\mathrm{HClO}_{4} / \mathrm{SiO}_{2},{ }^{21}$ $\mathrm{H}_{2} \mathrm{SO}_{4} / \mathrm{SiO}_{2},{ }^{22} \mathrm{BF}_{3} / \mathrm{SiO}_{2},{ }^{23} \mathrm{NaHSO}_{4} / \mathrm{SiO}_{2}{ }^{24}$ or zeolites HY-type, ${ }^{25}$ were successfully employed. Microwave, ${ }^{26}$ ultrasound irradiation ${ }^{27}$ and ionic liquids ${ }^{28}$ were also reported as efficient promoters to the synthesis of arylimidazoles. Other solid catalysts, such as $\mathrm{NaHSO}_{3}{ }^{29}$ or $\mathrm{I}_{2}^{30}$ and proline ${ }^{31}$ or tetrabutylammonium bromide $(\mathrm{TBAB})^{32}$ as organocatalysts, were also effective. Although many catalysts have been employed in the Radziszewski reaction, the use of Lewis acid catalysts such as metal triflates as $\mathrm{Yb}(\mathrm{OTf})_{3},{ }^{33}$ metal halides as $\mathrm{ZrCl}_{4},{ }^{34} \mathrm{Zn}(\mathrm{acac}){ }_{4}{ }^{27}$ or cerium ammonium nitrate ${ }^{35}$ are rare. Additionally, few examples of metal halide hydrates like $\mathrm{InCl}_{3} \cdot 3 \mathrm{H}_{2} \mathrm{O}^{36}$ and $\mathrm{NiCl}_{2} \cdot 6 \mathrm{H}_{2} \mathrm{O} / \mathrm{Al}_{2} \mathrm{O}_{3}{ }^{37}$ were reported for the synthesis of these compounds.

The previous experience of our research group on the use of highly moisture sensitive metal halides as Lewis acid catalysts in organic reactions ${ }^{38}$ prompt us to investigate the similar ability of the metal halide hydrates, which are cheaper, easily handled and compatible moisture. Fortunately, our group discovered that $\mathrm{SnCl}_{2} \cdot 2 \mathrm{H}_{2} \mathrm{O}$ was successfully employed in the Biginelli reaction, ${ }^{39}$ Friedlander condensation ${ }^{40}$ and in conjugate Friedel-Crafts reaction. ${ }^{41}$ In the present work, we explore the ability of a series of metal chloride hydrates $\left(\mathrm{SnCl}_{2} \cdot 2 \mathrm{H}_{2} \mathrm{O}, \mathrm{ZnCl}_{2} \cdot 2 \mathrm{H}_{2} \mathrm{O}, \mathrm{CdCl}_{2} \cdot 2 \mathrm{H}_{2} \mathrm{O}, \mathrm{MnCl}_{2} \cdot 4 \mathrm{H}_{2} \mathrm{O}\right.$, $\mathrm{CoCl}_{2} \cdot 6 \mathrm{H}_{2} \mathrm{O}, \mathrm{SrCl}_{2} \cdot 6 \mathrm{H}_{2} \mathrm{O}, \mathrm{NiCl}_{2} \cdot 6 \mathrm{H}_{2} \mathrm{O}, \mathrm{CrCl}_{3} \cdot 6 \mathrm{H}_{2} \mathrm{O}$ and $\mathrm{CeCl}_{3} \cdot 7 \mathrm{H}_{2} \mathrm{O}$ ) as mild and inexpensive Lewis acid catalysts in the multicomponent Radziszewski reaction. Besides the search for catalyst efficiency, variables such as protic/aprotic solvents and molar ratio of reagents and catalyst were investigated towards the optimization of a general and useful protocol.

\section{Results and Discussion}

\section{Catalysts}

To investigate the abilities of metal chloride hydrates as Lewis acid catalysts, lophine (2,4,5-triphenyl$1 \mathrm{H}$-imidazole) (8a) was chosen as the model compound. In a first example, the reaction of benzil $(\mathbf{4 a}, 1.0 \mathrm{mmol})$, benzaldehyde (6a, $1.0 \mathrm{mmol}), \mathrm{NH}_{4} \mathrm{OAc}(\mathbf{7}, 4.0 \mathrm{mmol})$ and $\mathrm{SnCl}_{2} \cdot 2 \mathrm{H}_{2} \mathrm{O}(0.10 \mathrm{mmol})$ was carried out in gently refluxing EtOH. The course of the reaction was monitored by thin layer chromatography (TLC) and after a period of $4 \mathrm{~h}$, the starting materials were consumed. After this time, the reaction was stopped and the crude product was isolated (Table 1, entry 2). Therefore, this time was chosen as default for comparison with other catalysts (Scheme 1).

Table 1. Different metal chloride hydrate catalysts for the synthesis of lophine (8a)

\begin{tabular}{|c|c|c|c|c|c|}
\hline \multirow{2}{*}{ entry } & \multirow{2}{*}{ Catalyst } & \multirow{2}{*}{$\begin{array}{c}\text { Amount / } \\
\text { mmol }\end{array}$} & \multirow{2}{*}{ time / h } & \multicolumn{2}{|c|}{ 8a - Yield / \% } \\
\hline & & & & from $\mathbf{4 a}$ & from 5 \\
\hline 1 & - & - & 4 & 57 & 17 \\
\hline 2 & $\mathrm{SnCl}_{2} \cdot 2 \mathrm{H}_{2} \mathrm{O}$ & 0.1 & 4 & 91 & 67 \\
\hline 3 & $\mathrm{MnCl}_{2} \cdot 4 \mathrm{H}_{2} \mathrm{O}$ & 0.1 & 4 & 83 & 70 \\
\hline 4 & $\mathrm{ZnCl}_{2} \cdot 2 \mathrm{H}_{2} \mathrm{O}$ & 0.1 & 4 & 73 & 72 \\
\hline 5 & $\mathrm{CdCl}_{2} \cdot 2 \mathrm{H}_{2} \mathrm{O}$ & 0.1 & 4 & 76 & 61 \\
\hline 6 & $\mathrm{CoCl}_{2} \cdot 6 \mathrm{H}_{2} \mathrm{O}$ & 0.1 & 4 & 79 & 63 \\
\hline 7 & $\mathrm{SrCl}_{2} \cdot 6 \mathrm{H}_{2} \mathrm{O}$ & 0.1 & 4 & 78 & 63 \\
\hline 8 & $\mathrm{NiCl}_{2} \cdot 6 \mathrm{H}_{2} \mathrm{O}$ & 0.1 & 4 & 76 & 63 \\
\hline 9 & $\mathrm{CrCl}_{3} \cdot 6 \mathrm{H}_{2} \mathrm{O}$ & 0.1 & 4 & 73 & 65 \\
\hline 10 & $\mathrm{CeCl}_{3} \cdot 7 \mathrm{H}_{2} \mathrm{O}$ & 0.1 & 4 & 77 & 88 \\
\hline 11 & $\mathrm{SnCl}_{2} \cdot 2 \mathrm{H}_{2} \mathrm{O}$ & 0.05 & 4 & 82 & - \\
\hline 12 & $\mathrm{CeCl}_{3} \cdot 7 \mathrm{H}_{2} \mathrm{O}$ & 0.05 & 4 & - & 68 \\
\hline 13 & $\mathrm{CeCl}_{3} \cdot 7 \mathrm{H}_{2} \mathrm{O}$ & 0.1 & 2 & - & 55 \\
\hline 14 & $\mathrm{CeCl}_{3} \cdot 7 \mathrm{H}_{2} \mathrm{O}$ & 0.1 & 6 & - & 92 \\
\hline
\end{tabular}



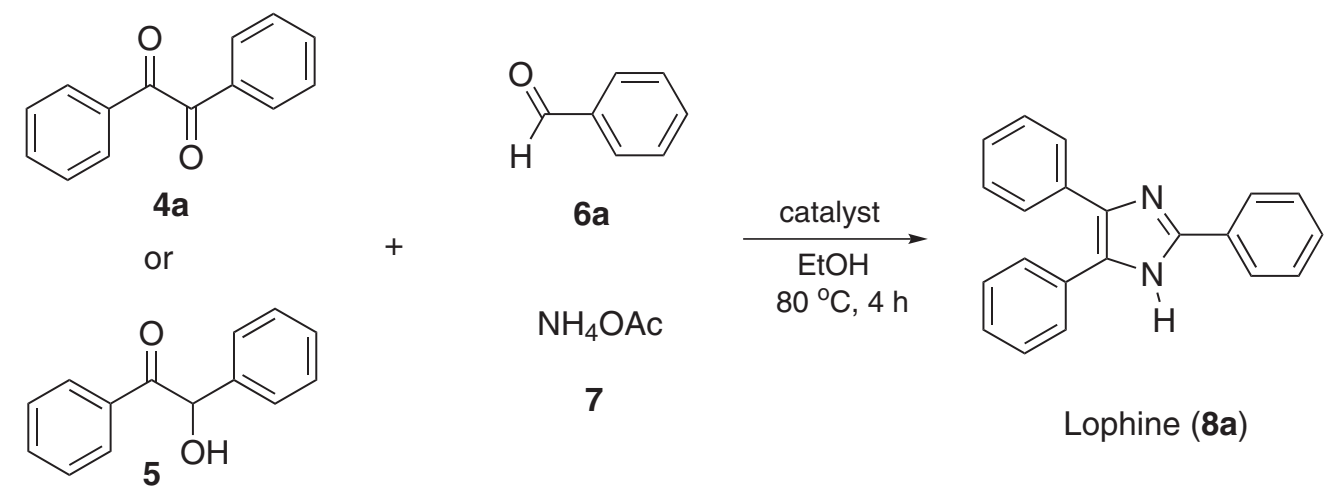

Scheme 1. The three-component Radziszewski reaction.

The same conditions were applied for the reactions with benzoin $(5,1.0 \mathrm{mmol})$ instead of benzil, and the results are shown in the Table 1. In all cases, the metal chloride hydrates showed catalytic activity affording lophine in variable yield. It should be noted that in the absence of the catalyst, the yield was drastically reduced, evidencing the metal halide activity (see Table 1, entry 1 ). The best results (higher than $80 \%$ yield) starting from benzil (4) were found in the presence of $\mathrm{SnCl}_{2} \cdot 2 \mathrm{H}_{2} \mathrm{O}$ and $\mathrm{MnCl}_{2} \cdot 2 \mathrm{H}_{2} \mathrm{O}$ (entries 2 and 3, respectively). On the other hand, the optimum result with benzoin (5) was achieved in the presence of $\mathrm{CeCl}_{3} \cdot 7 \mathrm{H}_{2} \mathrm{O}$ (entry 10). The decrease in the catalyst amount from 0.10 to $0.05 \mathrm{mmol}$ afforded worse results for both starting ketones (entries 11 and 12). Finally, the reactions that were carried out for $2 \mathrm{~h}$ caused a decrease in the yield of the product, while an increase of $6 \mathrm{~h}$ in the time of the reaction led only to a small improvement (cf. entries 10 and 14, respectively). Therefore, it was decided to explore the use of $\mathrm{SnCl}_{2} \cdot 2 \mathrm{H}_{2} \mathrm{O}$ and $\mathrm{CeCl}_{3} \cdot 7 \mathrm{H}_{2} \mathrm{O}(0.10 \mathrm{mmol})$ as the main catalysts and the time of $4 \mathrm{~h}$ as default.
Different mechanistic pathways have been proposed for this multicomponent reaction having the benzil or benzoin as starting materials. ${ }^{15,28,33}$ The proposed rationale by Kokare et al. ${ }^{19}$ seems to be in accordance with the results in Table 1 (Scheme 2). The authors suggested the initial formation of $N, N$-ketal (9) under Brønsted acidic catalysis from benzaldehyde (6a) and 2 equivalents of $\mathrm{NH}_{4} \mathrm{OAc}$ (7). It was assumed that the same activation occurs in the Lewis catalysis. Therefore, the condensation of 9 with benzil (4a) after losing 2 equivalents of water, leads to the conjugate intermediate $\mathbf{1 0}$ which rearranges via a [1,5]-sigmatropic proton shift to afford the corresponding lophine (8a).

On the other hand, starting from benzoin, the cyclization of intermediate imino-alcohol (11) should occur by an intramolecular attack of nitrogen in a more hindered and saturated carbon to afford the dihydroimidazole intermediate (12) (Scheme 3). Additionally, the needed oxidation step to produce the conjugated intermediate (10) could be corroborating to explain the minor reactivity that is observed in reactions starting from benzoin. The intermediate $(\mathbf{1 0})$ is suggested as common specie in both mechanistic pathways.<smiles>N#C[Pb]C(N)N</smiles><smiles></smiles>

10

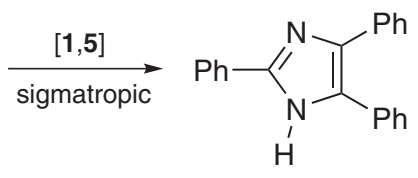

$8 a$

Scheme 2. Suggested mechanistic pathway starting from benzil (4a).<smiles>O=C(c1ccccc1)C(O)c1ccccc1</smiles>

5

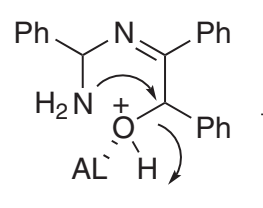

11<smiles>c1ccc(-c2ccccc2)cc1</smiles>

12

Scheme 3. Suggested mechanistic pathway starting from benzoin (5). 


\section{Solvent}

Despite the use of $\mathrm{H}_{2} \mathrm{O},{ }^{42} \mathrm{MeOH}$, EtOH, $i-\mathrm{PrOH}$, $\mathrm{CH}_{2} \mathrm{Cl}_{2}$, THF, 1,4-dioxane ${ }^{43}$ or $\mathrm{CH}_{3} \mathrm{CN}^{34}$ as solvents has already been reported in presence of different catalysts, the relative influence of alcoholic solvents in the Radziszewski reaction was not well studied. For this purpose, were investigated the reactions of benzil $(\mathbf{4 a}, 1 \mathrm{mmol})$ or benzoin $(\mathbf{5}, 1 \mathrm{mmol})$, benzaldehyde (6a, $1.0 \mathrm{mmol}), \mathrm{NH}_{4} \mathrm{OAc}(\mathbf{7}$, $4.0 \mathrm{mmol})$ and the catalyst $(0.10 \mathrm{mmol})$ carried out in $\mathrm{MeOH}, \mathrm{EtOH}, n-\mathrm{PrOH}, \mathrm{CH}_{3} \mathrm{CN}$ and THF (tetrahydrofuran) promoted by $\mathrm{SnCl}_{2} \cdot 2 \mathrm{H}_{2} \mathrm{O}$ or $\mathrm{CeCl}_{3} \cdot 7 \mathrm{H}_{2} \mathrm{O}$ for the synthesis of lophine ( $\mathbf{8 a}$, Scheme 4). The results are shown in the Table 2, bellow.

Table 2 shows the solvents, their dipole moments $(\mu)$ and relative dielectric constants $(\varepsilon){ }^{44}$ The reaction from benzyl in the presence of $\mathrm{SnCl}_{2} \cdot 2 \mathrm{H}_{2} \mathrm{O}$ seems to be more influenced by the solvent (Table 2, entries 1-5). Aprotic solvents led to poorer yields. In the case of $\mathrm{CH}_{3} \mathrm{CN}$ (the most polar between them), the solvent might be associating to the catalyst in a stronger way than the other ones do,<smiles>O=C(C(=O)c1ccccc1)c1ccccc1</smiles><smiles>O=Cc1ccccc1</smiles><smiles>O=C(c1ccccc1)C(O)c1ccccc1</smiles>
$+$ $\mathrm{NH}_{4} \mathrm{OAc}$

\section{7}

reducing more significantly the reaction rate (entry 4). On the other hand, from benzoin and $\mathrm{CeCl}_{3} \cdot 7 \mathrm{H}_{2} \mathrm{O}$, the yields are essentially the same for all the solvents, protic or aprotic (entries 6-10). The effect of $\mathrm{CH}_{3} \mathrm{CN}$ is not observed, which might be attributed to the metal volume, making their association more difficult (entry 9). Besides the effects of polarity of the solvents, their ability in acting as "hydrogen bond donors" can be considered. This new principle can be evidenced in the activation process through the hydrogen bonding between the solvent and reactants on organocatalyzed reactions, as recently reviewed by Akiyama. ${ }^{45}$ Therefore, based on the results above discussed and on economical and ambient sustainability reasons, lower toxicity and easy availability, ethanol becomes more advantageous solvent and was chosen as a default solvent in our present study.

\section{Molar ratio of $\mathrm{NH}_{4} \mathrm{OAc}$}

Next, it was investigated the influence of the molar ratio of $\mathrm{NH}_{4} \mathrm{OAc}$ on the synthesis of lophine under catalysis of

\section{5}

Scheme 4. Synthesis of lophine (8a) under different solvents.

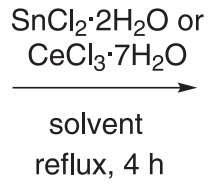

reflux, $4 \mathrm{~h}$

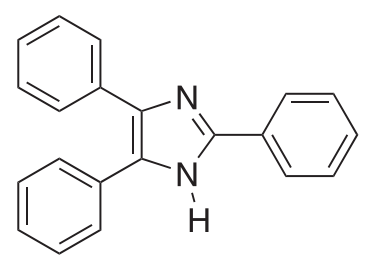

Lophine (8a)

Table 2. Synthesis of lophine via Scheme 4

\begin{tabular}{|c|c|c|c|c|c|c|}
\hline entry & Ketone $^{a}$ & Catalyst $^{\mathrm{b}}$ & Solvent & $\mu /$ debye & $\varepsilon_{\mathrm{R}}$ & $\mathbf{8 a}$ - Yield / \% \\
\hline 1 & $4 a$ & $\mathrm{SnCl}_{2} \cdot 2 \mathrm{H}_{2} \mathrm{O}$ & $\mathrm{MeOH}$ & 1.70 & 32.6 & 79 \\
\hline 2 & $4 \mathbf{a}$ & $\mathrm{SnCl}_{2} \cdot 2 \mathrm{H}_{2} \mathrm{O}$ & $\mathrm{EtOH}$ & 1.69 & 24.3 & 89 \\
\hline 3 & $4 a$ & $\mathrm{SnCl}_{2} \cdot 2 \mathrm{H}_{2} \mathrm{O}$ & $n-\mathrm{PrOH}$ & 1.55 & 20.1 & 78 \\
\hline 4 & $4 \mathbf{a}$ & $\mathrm{SnCl}_{2} \cdot 2 \mathrm{H}_{2} \mathrm{O}$ & $\mathrm{CH}_{3} \mathrm{CN}$ & 3.92 & 37.5 & 65 \\
\hline 5 & $4 \mathbf{a}$ & $\mathrm{SnCl}_{2} \cdot 2 \mathrm{H}_{2} \mathrm{O}$ & THF & 1.75 & 7.6 & 75 \\
\hline 6 & 5 & $\mathrm{CeCl}_{3} \cdot 7 \mathrm{H}_{2} \mathrm{O}$ & $\mathrm{MeOH}$ & 1.70 & 32.6 & 88 \\
\hline 7 & 5 & $\mathrm{CeCl}_{3} \cdot 7 \mathrm{H}_{2} \mathrm{O}$ & $\mathrm{EtOH}$ & 1.69 & 24.3 & 88 \\
\hline 8 & 5 & $\mathrm{CeCl}_{3} \cdot 7 \mathrm{H}_{2} \mathrm{O}$ & $n-\mathrm{PrOH}$ & 1.55 & 20.1 & 85 \\
\hline 9 & 5 & $\mathrm{CeCl}_{3} \cdot 7 \mathrm{H}_{2} \mathrm{O}$ & $\mathrm{CH}_{3} \mathrm{CN}$ & 3.92 & 37.5 & 80 \\
\hline 10 & 5 & $\mathrm{CeCl}_{3} \cdot 7 \mathrm{H}_{2} \mathrm{O}$ & THF & 1.75 & 7.6 & 81 \\
\hline
\end{tabular}

${ }^{\mathrm{a}} 1 \mathrm{mmol} ;{ }^{\mathrm{b}} 0.1 \mathrm{mmol}$. 
$\mathrm{SnCl}_{2} \cdot 2 \mathrm{H}_{2} \mathrm{O}$ and $\mathrm{CeCl}_{3} \cdot 7 \mathrm{H}_{2} \mathrm{O}$. The molar ratio of benzil (4a, $1.0 \mathrm{mmol})$ or benzoin $(\mathbf{5}, 1.0 \mathrm{mmol})$, benzaldehyde $(\mathbf{6 a}$, $1.0 \mathrm{mmol})$ and catalyst $(0.10 \mathrm{mmol})$ were the same for all performed assays. The results are shown in Table 3. From substrates, $\mathbf{4 a}$ or $\mathbf{5}$, the increase in the $\mathrm{NH}_{4} \mathrm{OAc}$ amount from 2 to $4 \mathrm{mmol}$ was followed by an improvement on the reaction yield ( $c f$. entries 1, 2 and 4, 5, respectively).

Table 3. Synthesis of lophine (8a) under different molar ratio of $\mathrm{NH}_{4} \mathrm{OAc}$

\begin{tabular}{lcccc}
\hline entry & Ketone & Catalyst & $\mathrm{NH}_{4} \mathrm{OAc} / \mathrm{mmol}$ & $\mathbf{8 a}-$ Yield $/ \%$ \\
\hline 1 & $\mathbf{4 a}$ & $\mathrm{SnCl}_{2} \cdot 2 \mathrm{H}_{2} \mathrm{O}$ & 2 & 45 \\
2 & $\mathbf{4 a}$ & $\mathrm{SnCl}_{2} \cdot 2 \mathrm{H}_{2} \mathrm{O}$ & 4 & 91 \\
3 & $\mathbf{4 a}$ & $\mathrm{SnCl}_{2} \cdot 2 \mathrm{H}_{2} \mathrm{O}$ & 10 & 96 \\
4 & $\mathbf{5}$ & $\mathrm{CeCl}_{3} \cdot 7 \mathrm{H}_{2} \mathrm{O}$ & 2 & 38 \\
5 & $\mathbf{5}$ & $\mathrm{CeCl}_{3} \cdot 7 \mathrm{H}_{2} \mathrm{O}$ & 4 & 88 \\
6 & $\mathbf{5}$ & $\mathrm{CeCl}_{3} \cdot 7 \mathrm{H}_{2} \mathrm{O}$ & 10 & 64 \\
\hline
\end{tabular}

From substrates, benzyl or benzoin, the increase in the $\mathrm{NH}_{4} \mathrm{OAc}$ amount from 2 to $4 \mathrm{mmol}$ was followed of an improvement on the reaction yield ( $c f$. entries 1 , 2 and 4, 5, respectively). Using $10 \mathrm{mmol}$ of $\mathrm{NH}_{4} \mathrm{OAc}$, a little improvement from benzyl was observed (entry 3 ). In contrast, a poorer yield from benzoin (entry 6) was achieved. In summary, $4 \mathrm{mmol}$ ( 2 molar equivalents) were considered the optimum amount of this reagent. This developed protocol was applied to the reaction of benzils (4a-c) and benzoin (5) with aldehydes (6a-k) to afford a library of triarylimidazoles (8a-p) (Scheme 5). The results are show in the Table 4.

\section{Pyrazine and triaryloxazoles}

The decrease in the yield when $10 \mathrm{mmol}$ of $\mathrm{NH}_{4} \mathrm{OAc}$ was employed with benzoin ( $\mathbf{5}$, see Table $\mathbf{3}$, entry 6 ) was<smiles>[R16]c1ccc(C(=O)C(=O)c2ccc([R1])cc2)cc1</smiles><smiles>O=C(c1ccccc1)C(O)c1ccccc1</smiles>
$+$

$$
\mathrm{NH}_{4} \mathrm{OAc}
$$$$
7
$$

attributed to the formation of pyrazine (13) as a byproduct (identified by GC-MS analysis).

Similar observation was already reported in the literature. ${ }^{15}$ Intending to confirm this hypothesis, it was performed the reaction of benzoin $(5,2.0 \mathrm{mmol}), \mathrm{NH}_{4} \mathrm{OAc}$ (7, $4.0 \mathrm{mmol})$ under refluxing of ethanol and $\mathrm{CeCl}_{3} \cdot 7 \mathrm{H}_{2} \mathrm{O}$ $(0.10 \mathrm{mmol})$ over $4 \mathrm{~h}$ in absence of the aldehyde. After this time, the pyrazine (13) was isolated in $87 \%$ yield (Scheme 6).

On the other hand, the reaction of benzil (4a, $2.0 \mathrm{mmol})$ with ammonium acetate $(7,4.0 \mathrm{mmol})$ under refluxing of ethanol and $\mathrm{SnCl}_{2} \cdot 2 \mathrm{H}_{2} \mathrm{O}(0.10 \mathrm{mmol})$ over $4 \mathrm{~h}$ afforded the triaryloxazole (10a) in 74\% yield (Scheme 7).

Davidson et al. ${ }^{15}$ early reported the formation of 2,4,5-trifenyloxazole as a lateral product in the Radziszewski reaction under acetic acid media. By the proposed mechanistic pathway suggested by Davidson et al., ${ }^{15}$ it is clear the aid of acetic acid as a Brønsted acid catalyst. Triaryloxazoles are structurally similar to triarylimidazoles and also have some of their properties, but have been less studied so far. Due to their broad application (for example, in nonlinear optical devices ${ }^{46}$ or as biologically active compounds), ${ }^{47}$ it was decided to investigate the ability of metal chloride hydrates such as $\mathrm{NiCl}_{2} \cdot 6 \mathrm{H}_{2} \mathrm{O}, \mathrm{ZnCl}_{2} \cdot 2 \mathrm{H}_{2} \mathrm{O}$, $\mathrm{MnCl}_{2} \cdot 4 \mathrm{H}_{2} \mathrm{O}$ and $\mathrm{SnCl}_{2} \cdot 2 \mathrm{H}_{2} \mathrm{O}$ to participate as Lewis acid catalysts in the synthesis of triaryloxazoles. The results are shown in Table 5.

The reactions were carried out as described in the synthesis of lophine (see Table 1). In the absence of the catalyst (Table 5, entry 1), 10a was only isolated in a poor yield. The same result was observed when $\mathrm{NiCl}_{2} \cdot 6 \mathrm{H}_{2} \mathrm{O}$ or $\mathrm{MnCl}_{2} \cdot 4 \mathrm{H}_{2} \mathrm{O}$ was added (entries 2 and 3 ). Changing the catalyst to $\mathrm{ZnCl}_{2} \cdot 2 \mathrm{H}_{2} \mathrm{O}$, an increase in the yield was observed. In the presence of $\mathrm{SnCl}_{2} \cdot 2 \mathrm{H}_{2} \mathrm{O}$, a reasonable yield (78\%) was achieved (entries 4 and 5, respectively). Other solvents were also investigated. The reactions were carried

5

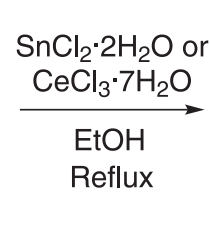

Triarylimidazoles

(8a-p) 
Table 4. Triarylimidazoles from different aromatic aldehydes

\begin{tabular}{|c|c|c|c|c|c|}
\hline \multirow{2}{*}{ entry } & \multirow{2}{*}{$\frac{\text { Ketone }(\mathbf{4}, \mathbf{5})}{\mathrm{R}^{1}}$} & \multirow{2}{*}{$\frac{\text { Aldehyde (6) }}{\mathrm{Ar}}$} & \multicolumn{2}{|c|}{ Catalyst - yield / \% } & \multirow{2}{*}{ Imidazoles $(\mathbf{8})$} \\
\hline & & & $\mathrm{SnCl}_{2} \cdot 2 \mathrm{H}_{2} \mathrm{O}^{\mathrm{a}}$ & $\mathrm{CeCl}_{3} \cdot 7 \mathrm{H}_{2} \mathrm{O}^{\mathrm{b}}$ & \\
\hline 1 & $\mathrm{H}(\mathbf{4 a}, \mathbf{5})$ & $\mathrm{C}_{6} \mathrm{H}_{5}(\mathbf{6 a})$ & 94 & 81 & 8a \\
\hline 2 & $\mathrm{H}(\mathbf{4 a}, \mathbf{5})$ & $4-(\mathrm{HO}) \mathrm{C}_{6} \mathrm{H}_{4}(\mathbf{6 b})$ & 96 & 81 & $8 \mathbf{b}$ \\
\hline 3 & $\mathrm{H}(\mathbf{4 a}, \mathbf{5})$ & $4-\left(\mathrm{CH}_{3} \mathrm{O}\right) \mathrm{C}_{6} \mathrm{H}_{4}(\mathbf{6 c})$ & 95 & 91 & $8 c$ \\
\hline 4 & $\mathrm{H}(\mathbf{4 a}, \mathbf{5})$ & $3,4-\left(\mathrm{CH}_{3} \mathrm{O}\right)_{2} \mathrm{C}_{6} \mathrm{H}_{3}(\mathbf{6 d})$ & 92 & 62 & $8 d$ \\
\hline 5 & $\mathrm{H}(\mathbf{4 a}, \mathbf{5})$ & 1-naphthyl (6e) & 61 & 85 & $8 e$ \\
\hline 6 & $\mathrm{H}(\mathbf{4 a}, \mathbf{5})$ & $4-(\mathrm{CN}) \mathrm{C}_{6} \mathrm{H}_{4}(\mathbf{6 f})$ & 71 & 83 & $8 f$ \\
\hline 7 & $\mathrm{H}(\mathbf{4} \mathbf{a}, \mathbf{5})$ & $3-\left(\mathrm{NO}_{2}\right) \mathrm{C}_{6} \mathrm{H}_{4}(\mathbf{6 g})$ & 91 & 87 & $8 g$ \\
\hline 8 & $\mathrm{H}(\mathbf{4 a}, \mathbf{5})$ & 2-( $\left(\mathrm{NO}_{2}\right) \mathrm{C}_{6} \mathrm{H}_{4}(\mathbf{6 h})$ & 74 & 60 & $8 \mathrm{~h}$ \\
\hline 9 & $\mathrm{H}(\mathbf{4 a}, \mathbf{5})$ & 2 -furyl (6i) & 73 & 69 & $8 \mathbf{i}$ \\
\hline 10 & $\mathrm{H}(\mathbf{4 a}, \mathbf{5})$ & 2-thienyl (6j) & 75 & 82 & $8 \mathbf{j}$ \\
\hline 11 & $\mathrm{H}(\mathbf{4 a}, \mathbf{5})$ & 3-thienyl (6k) & 94 & 84 & $8 k$ \\
\hline 12 & $\mathrm{CH}_{3} \mathrm{O}(\mathbf{4 b})$ & 3-thienyl (6k) & 98 & - & 81 \\
\hline 13 & $\mathrm{~F}(\mathbf{4 c})$ & $\mathrm{C}_{6} \mathrm{H}_{5}(\mathbf{6 a})$ & 87 & - & $8 m$ \\
\hline 14 & $\mathrm{~F}(\mathbf{4 c})$ & $4-(\mathrm{CN}) \mathrm{C}_{6} \mathrm{H}_{4}(\mathbf{6 f})$ & 64 & - & $8 n$ \\
\hline 15 & $\mathrm{~F}(\mathbf{4 c})$ & 2-furyl (6i) & 71 & - & 80 \\
\hline 16 & $\mathrm{~F}(\mathbf{4 c})$ & 3-thienyl (6k) & 92 & - & $8 p$ \\
\hline
\end{tabular}

${ }^{\mathrm{a} I n}$ reactions from benzil (4a); in reactions from benzoin $(\mathbf{5})$.<smiles>O=C(c1ccccc1)C(O)c1ccccc1</smiles>

Benzoin

(5)

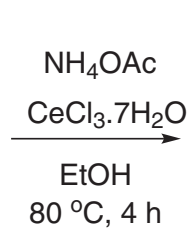

$80^{\circ} \mathrm{C}, 4 \mathrm{~h}$<smiles>c1ccc(-c2nc(-c3ccccc3)c(-c3ccccc3)nc2-c2ccccc2)cc1</smiles>

Pyrazine

(13)

Scheme 6. Synthesis of pyrazine (13) from benzoin (5).<smiles>[R7]c1ccc(C(=O)C(=O)c2ccc([R17]([H])([H])[R18]([H])([H])[H])cc2)cc1</smiles>

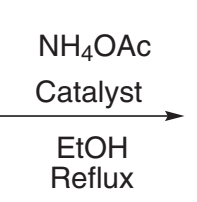

$\mathrm{R}$<smiles>[R7]c1ccc(-c2nc(-c3ccc([R7])cc3)c(-c3ccc([R7])cc3)o2)cc1</smiles>

Triaryloxazoles

$(14 a, b)$

Scheme 7. Synthesis of triaryloxazoles $(\mathbf{1 4 a}, \mathbf{b})$ from benzils $(\mathbf{4 a}, \mathbf{c})$.

out under reflux. In $\mathrm{MeOH}$, a decrease in the yield was observed, while the use of $n$ - $\mathrm{PrOH}$ permitted to isolate the product in a yield of $73 \%$ (entries 6 and 7 , respectively). On the other hand, in $\mathrm{CH}_{3} \mathrm{CN}$ and THF (aprotic polar solvents), benzyl was recovered after the work up (entries 8 and 9, respectively). So, EtOH was considered to be the best solvent. After that, the amount of catalyst was diminished from 10 to $5 \mathrm{~mol} \%$ ( $c f$. entries 5 and 10, respectively) and no significant decrease in the yield was observed, therefore, this new condition was set as default.

Finally, the increase in the reaction times also caused an increase in the yield of triaryloxazole (14a), 84 and 94\% (entries 11 and 12, respectively). The use of benzyl (4c) under the optimized protocol afforded the triaryloxazole 
Table 5. Synthesis of triaryloxazoles $\mathbf{1 4 a}$ and $\mathbf{1 4 b}$ from Scheme 7

\begin{tabular}{|c|c|c|c|c|c|c|}
\hline entry & Benzil & Catalyst / load ${ }^{a}$ & Solvent & time / h & Oxazole & Yield / \% \\
\hline 1 & $4 a$ & - & EtOH & 4 & $14 a$ & 15 \\
\hline 2 & $4 a$ & $\mathrm{NiCl}_{2} \cdot 6 \mathrm{H}_{2} \mathrm{O} / 0.10$ & $\mathrm{EtOH}$ & 4 & $14 a$ & 15 \\
\hline 3 & $4 a$ & $\mathrm{MnCl}_{2} \cdot 4 \mathrm{H}_{2} \mathrm{O} / 0.10$ & EtOH & 4 & $14 a$ & 15 \\
\hline 4 & $4 a$ & $\mathrm{ZnCl}_{2} \cdot 2 \mathrm{H}_{2} \mathrm{O} / 0.10$ & $\mathrm{EtOH}$ & 4 & $14 a$ & 56 \\
\hline 5 & $4 a$ & $\mathrm{SnCl}_{2} \cdot 2 \mathrm{H}_{2} \mathrm{O} / 0.10$ & EtOH & 4 & $14 a$ & 78 \\
\hline 6 & $4 a$ & $\mathrm{SnCl}_{2} \cdot 2 \mathrm{H}_{2} \mathrm{O} / 0.10$ & $\mathrm{MeOH}$ & 4 & $14 a$ & 44 \\
\hline 7 & $4 a$ & $\mathrm{SnCl}_{2} \cdot 2 \mathrm{H}_{2} \mathrm{O} / 0.10$ & $n-\mathrm{PrOH}$ & 4 & $14 a$ & 73 \\
\hline 8 & $4 a$ & $\mathrm{SnCl}_{2} \cdot 2 \mathrm{H}_{2} \mathrm{O} / 0.10$ & $\mathrm{CH}_{3} \mathrm{CN}$ & 4 & $14 a$ & - \\
\hline 9 & $4 a$ & $\mathrm{SnCl}_{2} \cdot 2 \mathrm{H}_{2} \mathrm{O} / 0.10$ & THF & 4 & $14 a$ & - \\
\hline 10 & $4 a$ & $\mathrm{SnCl}_{2} \cdot 2 \mathrm{H}_{2} \mathrm{O} / 0.05$ & EtOH & 4 & $14 a$ & 74 \\
\hline 11 & $4 a$ & $\mathrm{SnCl}_{2} \cdot 2 \mathrm{H}_{2} \mathrm{O} / 0.05$ & EtOH & 6 & $14 a$ & 84 \\
\hline 12 & $4 a$ & $\mathrm{SnCl}_{2} \cdot 2 \mathrm{H}_{2} \mathrm{O} / 0.05$ & $\mathrm{EtOH}$ & 18 & $14 a$ & 94 \\
\hline 13 & $4 c$ & $\mathrm{SnCl}_{2} \cdot 2 \mathrm{H}_{2} \mathrm{O} / 0.05$ & EtOH & 18 & $14 \mathrm{~b}$ & 93 \\
\hline
\end{tabular}

aThe load of catalyst in mmol.

(14b) in good yield, confirming the applicability of this protocol.

\section{Conclusions}

We found that the metal halide hydrates were active as Lewis acid catalyst to prepare 2,4,5-triarylimidazoles in reasonable to good yields through the Radziszewski multicomponent synthesis. These catalysts were effective starting from benzoin, as well as from benzils. The $\mathrm{SnCl}_{2} \cdot 2 \mathrm{H}_{2} \mathrm{O}$ showed the best results in reactions from benzyl, while $\mathrm{CeCl}_{3} \cdot 7 \mathrm{H}_{2} \mathrm{O}$ was more effective with benzoin. Additionally, we demonstrate that the molar ratio of $\mathrm{NH}_{4} \mathrm{OAc}$ is important to improve the yields of the products and the large excess of them can leads to the formation of 1,2,4,5-tetraarylpyrazines. The $\mathrm{SnCl}_{2} \cdot 4 \mathrm{H}_{2} \mathrm{O}$ was also effective to promote the reaction of benzils with $\mathrm{NH}_{4} \mathrm{OAc}$ to afford the respective triaryloxazoles in good yields.

\section{Experimental}

\section{General considerations}

The solvents and reagents were used without previous treatment, except for benzaldehyde, anisaldehyde and furfural, which were distilled prior to use. The reactions were monitored by thin layer chromatography (TLC) on ALUGRAM $^{\oplus}$ SIL G/UV 254 Macherey-Nagel silicagel plates. A mixture $\mathrm{CH}_{2} \mathrm{Cl}_{2} / \mathrm{AcOEt}$ in 98:2 ratios was used as eluent. The plates were visualized in alcoholic solution of 2,4-dinitrofenilidrazine or under UV light $(254 \mathrm{~nm})$. The ${ }^{1} \mathrm{H}$ and ${ }^{13} \mathrm{C}$ nuclear magnetic resonance (NMR) spectra were recorded in DMSO- $d_{6}$ using a Varian VNMRS or a Varian Mercury spectrometers at 300/400 MHz and 75/100 MHz, respectively. The chemical shifts $(\delta)$ are reported in parts per million (ppm) relative to DMSO- $d_{6}$ at $\delta 2.50 \mathrm{ppm}$ for ${ }^{1} \mathrm{H}$ NMR and the line at $\delta 39.5 \mathrm{ppm}$ for ${ }^{13} \mathrm{C}$ NMR. The coupling constants $J$ are reported in Hz. The following abbreviations are used for the multiplicities: s (singlet), $\mathrm{d}$ (doublet), dd (double of doublets), $\mathrm{t}$ (triplet), q (quartet), $\mathrm{m}$ (multiplet) and br s (broad singlet). The infrared (IR) spectra were recorded on a Perkin-Elmer Spectrum One, between 4000 and $600 \mathrm{~cm}^{-1}$ (Nujol). The melting points (mp) were measured on an Uniscience Brazil fusing equipment (model 498) and are uncorrected. The mass spectra (MS) were recorded on a GC-MS QP 2010 Shimadzu (EI, 70 eV).

\section{General procedures}

Synthesis of 2,4,5-triarylimidazoles (8a-p) from benzyls (4a-c)

A $10 \mathrm{~mL}$ round-bottom flask equipped with magnetic stirrer was charged with benzyls $(\mathbf{4 a - c})(1.0 \mathrm{mmol})$, aldehydes (6a-k) $(1.0 \mathrm{mmol}), \mathrm{NH}_{4} \mathrm{OAc}(7,4.0 \mathrm{mmol})$ and $\mathrm{SnCl}_{2} \cdot 2 \mathrm{H}_{2} \mathrm{O}(0.10 \mathrm{mmol})$, followed by EtOH $(4 \mathrm{~mL})$. The reaction mixture was stirred and gently refluxed for $4 \mathrm{~h}$. After the completion of the reaction with the monitoring of TLC, $4 \mathrm{~mL}$ of water were added. The solid was filtered under reduced pressure and washed with small portions of a mixture of cooled EtOH/ $\mathrm{H}_{2} \mathrm{O}(1: 1, \mathrm{v}: \mathrm{v})$. The crude product was recrystallized from acetone/water 9:1 or toluene.

Synthesis of 2,4,5-triarylimidazoles (8a-k) from the benzoin (5)

A $10 \mathrm{~mL}$ round-bottom flask equipped with magnetic stirrer was charged with benzoin $(\mathbf{5})(1.0 \mathrm{mmol})$, 
aldehydes (6a-k) (1.0 mmol), $\mathrm{NH}_{4} \mathrm{OAc}(\mathbf{7}, 4.0 \mathrm{mmol})$ and $\mathrm{CeCl}_{3} .7 \mathrm{H}_{2} \mathrm{O}(0.10 \mathrm{mmol})$, followed by EtOH $(4 \mathrm{~mL})$. The reaction mixture was stirred and gently refluxed for $4 \mathrm{~h}$. After the completion of the reaction with the monitoring of TLC, $4 \mathrm{~mL}$ of water were added. The solid was filtered under reduced pressure and washed with small portions of a mixture of cooled $\mathrm{EtOH} / \mathrm{H}_{2} \mathrm{O}(1: 1, \mathrm{v}: \mathrm{v})$. The crude product was recrystallized from acetone/water 9:1 or toluene.

Synthesis of 2,4,5-triaryloxazoles $(\mathbf{1 4 a , b})$ from benzyls $(4 a, c)$

A $10 \mathrm{~mL}$ round-bottom flask equipped with magnetic stirrer was charged with benzyls $(\mathbf{4 a}, \mathbf{c})(1.0 \mathrm{mmol})$, $\mathrm{NH}_{4} \mathrm{OAc}(7,5.0 \mathrm{mmol})$ and $\mathrm{SnCl}_{2} \cdot 2 \mathrm{H}_{2} \mathrm{O}(0.05 \mathrm{mmol})$, followed by $\mathrm{EtOH}(4 \mathrm{~mL})$. The reaction mixture was stirred and gently refluxed for $4 \mathrm{~h}$. After the completion of the reaction with the monitoring of TLC, $4 \mathrm{~mL}$ of water were added. The solid was filtered under reduced pressure and washed with small portions of a mixture of cooled $\mathrm{EtOH} / \mathrm{H}_{2} \mathrm{O}(1: 1, \mathrm{v}: \mathrm{v})$. The crude product was recrystallized from acetone/water 9:1 or toluene.

\section{Supplementary Information}

Supplementary data (spectral data of compounds 8a-p and 10a,b and spectra) are available free of charge at http://jbcs.org.br as PDF file.

\section{Acknowledgments}

The authors would like to acknowledge FAPERGS (Fundação de Amparo à Pesquisa do Estado do Rio Grande do Sul) and CNPq (Conselho Nacional de Desenvolvimento Cientifico e Tecnológico, Grant 2007-6/484615) for financial support and graduate fellowship (M. V. M).

\section{References}

1. For reviews on the chemistry of imidazoles, see: Grimmett, M. R. In Comprehensive Heterocyclic Chemistry, vol. 5; Katritzky, A. R.; Rees, C. W., eds.; Pergamon: Oxford, 1984; Grimmett, M. R. In Science of Synthesis, vol. 12; Neier R., ed.; Thieme: Stuttgart, 2002.

2. Palkowitz, A. D.; Steinberg, M. I.; Thrasher, K. J.; Reel, J. K.; Hauser, K. L.; Zimmerman, K. M.; Wiest, S. A.; Whitesitt, C. A.; Simon, R. L.; Pfeifer, W.; Lifer, S. L.; Boyd, D. B.; Barnett, D. J.; Wilson, T. M.; Deeter, J. B.; Kakeuchi, K.; Riley, R. E.; Miller, W. D.; Marshall, W. S.; J. Med. Chem. 1994, 37, 4508.

3. Trujillo, J. I.; Kiefer, J. R.; Huang, W.; Thorarensen, A.; Xing, L.; Caspers, N. L.; Day, J. E.; Mathis, K. J.; Kretzmer, K. K.;
Reitz, B. A.; Weinberg, R. A.; Stegeman, R. A.; Wrightstone, A.; Christine, L.; Compton, R.; Li, X.; Bioorg. Med. Chem. Lett. 2009, 19, 908.

4. Linda, L.; Chang, L. L.; Sidler, K. L.; Cascieri, M. A.; Laszlo, S.; Koch, G.; Li, B.; MacCoss, M.; Mantlo, N.; O’Keefe, S.; Pang, M.; Rolandoc, A.; Hagmanna, W. K.; Bioorg. Med. Chem. Lett. 2001, 11, 2549.

5. Sharma, D.; Narasimhan, B.; Kumar, P.; Judge, V.; Narang, R.; Clercq, E.; Balzarini, J.; Eur. J. Med. Chem. 2009, 44, 2347.

6. Kumar, S.; Boehm, J.; Lee, J. C.; Nat. Rev. Drug Disc. 2003 , 2,717 .

7. Laufer, S.; Koch, P.; Org. Biomol. Chem. 2008, 6, 437.

8. King, A. J.; Patrick, D. R.; Batorsky R. S.; Ho, M. L.; Do, H. T.; Zhang, S. Y.; Kumar, R.; Rusnak, A. K.; Wilson, D. M.; Hugger, E.; Wang, L.; Karreth, F.; Lougheed, J. C.; Lee, J.; Chau, D.; Stout, T. J.; May, E. W.; Rominger, C. M.; Schaber, M. D.; Luo, L.; Lakdawala, A. S.; Adams, J. L.; Contractor, R. G.; Smalley, K. S. M.; Herlyn, M.; Morrissey, M. M.; Tuveson, D. A.; Huang, P. S.; Cancer Res. 2006, 66, 11100.

9. Young, P. R; McLaughlin, M. M.; Kumari, S.; Kassisi, S.; Doyle, M. L.; McNulty, D.; Gallagher, T. F.; Fisher, S.; McDonnell, P. C.; Carr, S. A.; Huddleston, M. J.; Seibel, G.; Porter, T. G.; Livi, G. P.; Adams, J. L.; Leei, J. C.; J. Biol. Chem. 1997, 272, 12116.

10. Yagi, K.; Soong, C. F.; Irie, M.; J. Org. Chem. 2001, 66, 5419.

11. Fridman, N.; Speiser, S.; Kaftory, M.; Cryst. Growth Des. 2006 , $6,2281$.

12. Santos, J.; Mintz, E. A.; Zehnder, O.; Bosshard, C.; Bu, X. R.; Gunter, P.; Tetrahedron Lett. 2001, 42, 805.

13. Japp, F. R.; Robinson, H. H.; Ber. Dtsch. Chem. Ges. 1882, 15 , 1268.

14. Radziszewski, B.; Ber. Dtsch. Chem. Ges. 1882, 15, 1493.

15. Davidson, D.; Weiss, M.; Jelling, M.; J. Org. Chem. 1937, 2 , 319; Davidson, D.; Weiss, M.; Jelling, M.; J. Org. Chem. 1937, 2, 328 .

16. Kamijo, S.; Yamamoto, Y.; Chem. Asian J. 2007, 2, 568.

17. Khodaei, M. M.; Bahrami, K.; Kavianinia, I.; J. Chin. Chem. Soc. 2007, 54, 829.

18. Nagarapu, L.; Apuri, S.; Kantevari, S.; J. Mol. Catal. A: Chem. 2007, 266, 104.

19. Kokare, N. D.; Sangshetti, J. N.; Shinde, D. B.; Synthesis 2007, 2829.

20. Yadhav, S. D.; Kokare, N. D.; Jadhav S. D.; J. Heterocycl. Chem. 2008, 45, 1461.

21. Kantevari, S.; Vuppalapati, S. V. N.; Biradar, D. O.; Nagarapu, L.; J. Mol. Catal. A: Chem. 2007, 266, 109.

22. Shaabani, A.; Rahmati, A.; J. Mol. Catal. A: Chem. 2006, 249, 246.

23. Sadeghi, B.; Mirjalili, B. B. F.; Hashemi, M. M.; Tetrahedron Lett. 2008, 49, 2575.

24. Karimi,A. R.; Alimohammadi, Z.; Azizian, J.; Mohammadi,A.A.; Mohammadizadeh, M. R.; Catal. Commun. 2006, 7, 728. 
25. Sivakumar, K.; Kathirvel, A.; Lalitha, A.; Tetrahedron Lett. 2010, 51, 3018.

26. Shih, M.-H.; Tsai, C.-H.; Wang, Y.-C.; Shieh, M.-Y.; Lin, G.-L.; Wei, C.-Y.; Tetrahedron 2007, 63, 2990.

27. Khosropour, A. R.; Ultrason. Sonochem. 2008, 15, 659.

28. Siddiqui, S. A.; Narkhed, U. C.; Palimkar, S. S.; Daniel, T.; Lahoti, R. J.; Srinivasan, K. V.; Tetrahedron 2005, 61, 3539.

29. Sangshetti, J. N.; Kokare, N. D.; Kotharkar, S. A.; Shinde, D. B.; Monatsh. Chem. 2008, 139, 125.

30. Kidwai, M.; Mothsra, P.; Bansal, V.; Somvanshi, R. K.; Ethayathulla, A. S.; Dey, S.; Singh,T. P.; J. Mol. Catal. A: Chem. 2007, 265, 177.

31. Shitole, N. V.; Shelke, K. F.; Sonar, S. S.; Sadaphal, S. A.; Shingate, B. B.; Shingare, M. S.; Bull. Korean Chem. Soc. 2009, 30, 1963.

32. Chary, M. V.; Keerthysri, N. C.; Vupallapati, S. V. N.; Lingaiah, N.; Kantevari, S.; Catal. Commun. 2008, 9, 2013.

33. Wang, L.-M.; Wang, Y.-H.; Tian, H.; Yao, Y.-F.; Shao, J.-H.; Liu, B.; J. Fluorine Chem. 2006, 127, 1570.

34. Sharma, G. V. M.; Jyothi, Y.; Lakshmi, P. S.; Synth. Commun. 2006, 36, 2991.

35. Sun, Y.-F.; Huang, W.; Lu, C.-G.; Cui, Y.-P.; Dyes Pigm. 2009 , 81,10 .

36. Sharma, S. D.; Hazarika, P.; Konwar, D.; Tetrahedron Lett. 2008, 49, 2216.

37. Heravi, M. M.; Bakhtiari, K.; Oskooie, H. A.; Taheri, S.; J. Mol. Catal. A: Chem. 2007, 263, 279.

38. Russowsky, D.; Petersen, R. Z.; Godoi, M. N.; Pilli, R. A.; Tetrahedron Lett. 2000, 41, 9939; Andrade, C. K. Z.; Rocha, R. O.; Russowsky, D.; Godoi, M. N.; J. Braz. Chem. Soc. 2005, 16, 535; Godoi, M. N.; Costenaro, H. S.; Kramer, E.; Machado, P. S.; D’Oca, M. G. M.; Russowsky, D.; Quim. Nova 2005, 28,
1010; Silveira, C. C.; Vieira, A. S.; Braga, A. L.; Russowsky, D.; Tetrahedron 2005, 61, 9312; Russowsky, D.; Canto, R. F. S.; Sanches, S. A. A.; D’Oca, M. G. M.; Fatima, A.; Pilli, R. A.; Kohn, L. K.; Antonio, M. A.; de Carvalho, J. E.; Bioorg. Chem. 2006, 34, 173.

39. Russowsky, D.; Lopes, F. A.; Silva, V. S. S.; Canto, K. F. S.; D’Oca, M. G. M.; Godoi, M. N.; J. Braz. Chem. Soc. 2004, 15, 165.

40. Costa, J. S.; Pisoni, D. S.; Silva, C. B.; Petzhold, C. L.; Russowsky, D.; Ceschi, M. A.; J. Braz. Chem. Soc. 2009, 20, 1448.

41. Schwalm, C. S.; Ceschi, M. A.; Russowsky, D.; J. Braz. Chem. Soc. 2011, 22, 623.

42. Chauveau, E.; Marestin, C.; Schiets, F.; Mercier, R.; Green Chem. 2010, 12, 1018.

43. Chary, M. V.; Keerthysri, N. C.; Vupallapati, S. V. N.; Lingaiah, N.; Kantevari, S.; Catal. Commun. 2008, 9, 2013.

44. Lide, D. R.; Handbook of Chemistry and Physics, $79^{\text {th }}$ ed.; CRC Press: Boca Raton, 1993.

45. Akiyama, T. In Hydrogen Bonding in Organic Synthesis; Pihko, P. M., ed.; Wiley-VCH: Weinheim, 2009, chapter 2.

46. McCairn, M. C.; Culliford, S. J; Kozlowski, R. Z; Sutherland, A. J.; Tetrahedron Lett. 2004, 45, 2163.

47. Epple, R.; Cow, C.; Xie, Y.; Azimioara, M.; Russo, R.; Wang, X.; Wityak, J.; Karanewsky, D. S.; Tuntland, T.; Nguyen-Tran, V. T. B.; Ngo, C. C.; Huang, D.; Saez, E.; Spalding, T.; Gerken, A.; Iskandar, M.; Seidel, H. M.; Tian, S.-S.; J. Med. Chem. 2010, 53,77 . 


\title{
Metal Chloride Hydrates as Lewis Acid Catalysts in Multicomponent Synthesis of 2,4,5-Triarylimidazoles or 2,4,5-Triaryloxazoles
}

\author{
Marcelo V. Marques, ${ }^{a, b}$ Marcelo M. Ruthner, ${ }^{c}$ Luiz A. M. Fontoura ${ }^{*, a, c}$ and \\ Dennis Russowsky*,b \\ ${ }^{a}$ Departamento de Engenharia de Processos, Fundação de Ciência e Tecnologia, \\ 94930-230 Cachoeirinha-RS, Brazil \\ ${ }^{b}$ Laboratório de Sínteses Orgânicas, Instituto de Química, Universidade Federal do Rio Grande do Sul, \\ 91501-970 Porto Alegre-RS, Brazil
}

${ }^{c}$ Curso de Química, Universidade Luterana do Brasil, 92452-900 Canoas-RS, Brazil

Spectral characterization of compounds $\mathbf{8 a - p}$ and $\mathbf{1 0 a}, \mathbf{b}$

2,4,5-Triphenyl-1H-imidazole (lophine) (8a): solid; mp 278-279 ${ }^{\circ} \mathrm{C} ;{ }^{1}{ }^{1} \mathrm{H}$ NMR (300 MHz, DMSO- $\left.d_{6}\right) \delta 12.71$ (br s, 1H, NH), 8.09 (d, 2H, J 7.0 Hz), 7.14-7.70 (m, 13H); ${ }^{13} \mathrm{C}$ NMR (75 MHz, DMSO- $\left.d_{6}\right) \delta 145.4,137.0,135.1$, $131.0,130.2$, 128.6, 129.5, 128.4, 128.2, 128.1, 127.7, 127.0, 126.4, 125.1; IR (Nujol) $v_{\max } / \mathrm{cm}^{-1} 1600,1503,1128$, 966, 916; GC-MS (IE, 70 eV) $\mathrm{m} / \mathrm{z}$ (\%) $296\left(\mathrm{M}^{+}, 100.0\right), 165$ (48.0), 148 (12.6), 89 (17.1), 77 (7.0), 63 (7.3), 51 (4.0).

4-(4,5-Diphenyl-1H-imidazol-2-yl)phenol (8b): solid; mp 262-263 ${ }^{\circ} \mathrm{C} ;{ }^{2}{ }^{1} \mathrm{H}$ NMR (400 MHz, DMSO- $\left.d_{6}\right) \delta 9.61$ (br s, 1H, NH), 7.89 (d, 2H, J 8.3 Hz), 7.05-7.70 (m, 10H), $6.84(\mathrm{~d}, 2 \mathrm{H}, J 8.8 \mathrm{~Hz}) ;{ }^{13} \mathrm{C}$ NMR $\left(100 \mathrm{MHz}, \mathrm{DMSO}-d_{6}\right)$ $\delta$ 157.6, 145.9, 126.6, 121.5. 115.2; IR (Nujol) $\mathrm{v}_{\max } / \mathrm{cm}^{-1}$ 1643, 1613, 1546, 1506, 1490, 1240, 764, 698; GC-MS (IE, $70 \mathrm{eV}) \mathrm{m} / \mathrm{z}$ (\%) $312\left(\mathrm{M}^{+}, 100.0\right), 165$ (39.0), 89 (8.9), 77 (8.9), 51 (3.0), 39 (2.9).

2-(4-Methoxyphenyl)-4,5-diphenyl-1H-imidazole (8c): solid; mp 233-234 ${ }^{\circ} \mathrm{C} ;{ }^{1}{ }^{1} \mathrm{H}$ NMR (400 MHz, DMSO- $d_{6}$ ) $\delta 12.45$ (br s, 1H, NH), 8.01(d, 2H, J 8.8 Hz), 7.15-7.62 (m, $10 \mathrm{H}), 7.04(\mathrm{~d}, 2 \mathrm{H}, J 8.8 \mathrm{~Hz}), 3.82(\mathrm{~s}, 3 \mathrm{H}) ;{ }^{13} \mathrm{CNMR}(100 \mathrm{MHz}$, DMSO- $\left.d_{6}\right) \delta 55.1,59.4,145.6,128.2,126.6,123.1,114.0$; IR (Nujol) $v_{\max } / \mathrm{cm}^{-1} 1614,1546,1248,765,696$; GC-MS (IE, $70 \mathrm{eV}) \mathrm{m} / z(\%) 326\left(\mathrm{M}^{+}, 100.0\right), 311$ (22.4), 165 (14.0), 89 (6.3), 77 (6.3), 63 (3.0), 51 (2.9), 39 (1.8).

2-(3,4-Dimethoxyphenyl)-4,5-diphenyl-1H-imidazole (8d): solid; mp 250-251 ${ }^{\circ} \mathrm{C} ;{ }^{1}{ }^{1} \mathrm{H}$ NMR (400 MHz, DMSO- $d_{6}$ ) $\delta 12.46$ (br s, 1H, NH), 7.16-7.77 (m, 12H), 7.06 (d, 1H, $J 8.3 \mathrm{~Hz}), 3.86(\mathrm{~s}, 3 \mathrm{H}), 3.82(\mathrm{~s}, 3 \mathrm{H}) ;{ }^{13} \mathrm{C} \mathrm{NMR}(100 \mathrm{MHz}$,

*e-mail: dennis@iq.ufrgs.br
DMSO- $\left.d_{6}\right) \delta 55.4,55.5,149.0,148.7,148.1,145.5$, $137.8,129.4,128.4,128.2,128.1,127.9,127.4,126.9$, $126.2,123.1,117.8,111.8,108.9$; IR (Nujol) $v_{\max } / \mathrm{cm}^{-1}$ 1606, 1495, 765, 696; GC-MS (IE, 70 eV) $\mathrm{m} / z$ (\%) 326 $\left(\mathrm{M}^{+}, 100.0\right), 165$ (12.6), 89 (5.2), 77 (4.8), 63 (5.2), 51 (2.1).

2-(1-Naphtalen-1-yl)-4,5-diphenyl-1H-imidazole (8e): solid; mp 273-275 ${ }^{\circ} \mathrm{C} ;{ }^{1} \mathrm{H}$ NMR (400 MHz, DMSO- $d_{6}$ ) $\delta$ 12.71 (br s, 1H, NH), 8.01 (d, 2H, J 7.8 Hz), 7.98 (dd, 1H, $J 7.3$ and $1.0 \mathrm{~Hz}), 7.50-7.65(\mathrm{~m}, 7 \mathrm{H}), 7.20-7.47(\mathrm{~m}, 7 \mathrm{H})$; ${ }^{13} \mathrm{C}$ NMR $\left(100 \mathrm{MHz}, \mathrm{DMSO}-d_{6}\right) \delta 145.4,137.9,137.0$, $135.2,133.5,130.9,130.2,129.4,128.7,128.4,128.2$, $128.0,127.7,127.5,127.3,127.0,126.5,126.4,126.3$, 125.9, 125.0; IR (Nujol) $v_{\max } / \mathrm{cm}^{-1} 1596,1500,764,695$; GC-MS (IE, $70 \mathrm{eV}) \mathrm{m} / z$ (\%) $326\left(\mathrm{M}^{+}, 100.0\right), 165$ (37.4), 139 (9.3), 89 (6.0), 77 (4.1), 63 (3.3), 51 (1.9).

4-(4,5-Diphenyl-1H-imidazol-2-yl)benzonitrile (8f): solid; mp 248-250 ${ }^{\circ} \mathrm{C}$; ${ }^{1} \mathrm{H}$ NMR (300 MHz, DMSO- $d_{6}$ ) $\delta 13.03$ (br s, 1H, NH), 8.26 (d, 2H, J 8,2 Hz), 7.93 (d, $2 \mathrm{H}, J 8.2 \mathrm{~Hz}), 7.18-7.70(\mathrm{~m}, 10 \mathrm{H}) ;{ }^{13} \mathrm{C} \mathrm{NMR}(75 \mathrm{MHz}$, DMSO- $\left.d_{6}\right) \delta 143.6,138.0,134.6,134.2,132.7,130.5$, $129.5,128.6,128.4,128.2,128.0,127.0,126.7,125.4$, 118.8, 110.0; IR (Nujol) $v_{\max } / \mathrm{cm}^{-1} 2227,1610,1490,766$, 696; GC-MS (IE, $70 \mathrm{eV}) \mathrm{m} / z(\%) 321\left(\mathrm{M}^{+}, 100.0\right), 165$ (47.7), 89 (12.0), 77 (5.3), 63 (7.4), 51 (4.0); HRMS (ESI, $\left.\mathrm{w} / \mathrm{H}^{+}\right)$calcd. 321.13387, found 322.13394.

2-(3-Nitrophenyl)-4,5-diphenyl-1H-imidazole (8g): solid; mp 315-317 ${ }^{\circ} \mathrm{C} ;{ }^{4}{ }^{1} \mathrm{H}$ NMR (300 MHz, DMSO- $d_{6}$ ) $\delta$ 13.11 (br s, 1H, NH), 8.96 (s, 1H), 8.52 (d, 1H, J 7.7 Hz), 8.21 (dd, 1H, J 8.2 Hz), 7.77 (t, 1H, J 8.0 Hz), 7.22-7.64 $(\mathrm{m}, 10 \mathrm{H}) ;{ }^{13} \mathrm{C}$ NMR $\left(75 \mathrm{MHz}, \mathrm{DMSO}-d_{6}\right) \delta 148.3,143.4$, $137.7,134.7,131.8,131.2,130.6,130.4,129.2$, 128.7, $128.4,128.3,128.1,127.1,126.8,122.6,119.4$; IR (Nujol) 
$v_{\max } / \mathrm{cm}^{-1} 1541,1523,1348,777,699 ;$ GS-MS (IE, $70 \mathrm{eV}$ ) $\mathrm{m} / \mathrm{z}(\%) 341\left(\mathrm{M}^{+}, 100.0\right), 311(47.8), 295$ (21.1), 165 (42.6), 89 (22.0), 77 (13.2), 63 (3.3), 43 (2.2).

2-(2-Nitrophenyl)-4,5-diphenyl-1H-imidazole (8h): solid; mp 224-225 ${ }^{\circ} \mathrm{C} ;{ }^{5}{ }^{1} \mathrm{H}$ NMR $\left(300 \mathrm{MHz}\right.$, DMSO- $\left.d_{6}\right)$ $\delta 12.98(\mathrm{sl}, 1 \mathrm{H}, \mathrm{NH}), 8.00(\mathrm{~d}, 1 \mathrm{H}, J 7.6 \mathrm{~Hz}), 7.93(\mathrm{~d}, 1 \mathrm{H}$, $J 8.2 \mathrm{~Hz}), 7.79(\mathrm{t}, 1 \mathrm{H}, J 7.6 \mathrm{~Hz}), 7.64(\mathrm{t}, 1 \mathrm{H}, J 7.6 \mathrm{~Hz})$, 7.35-7.60 (m, 8H), $7.31(\mathrm{t}, 1 \mathrm{H}, J 7.0 \mathrm{~Hz}), 7.23(\mathrm{t}, 1 \mathrm{H}$, $J 7.0 \mathrm{~Hz}) ;{ }^{13} \mathrm{C}$ NMR $\left(75 \mathrm{MHz}, \mathrm{DMSO}-d_{6}\right) \delta 148.2,140.9$, $137.4,134.6,132.0,130.5,129.7,129.4,128.7,128.6$, 128.2, 128.1, 127.9, 126.9, 126.6, 123.9,123.3; IR (Nujol) $v_{\max } / \mathrm{cm}^{-1} 1601,1524,1502,1364,724,694$; GC-MS (IE, $70 \mathrm{eV}) \mathrm{m} / \mathrm{z}$ (\%) $341\left(\mathrm{M}^{+}, 59.7\right), 311$ (100.0), 207 (15.0), 165 (40.1), 147 (14.2), 135 (21.3), 104 (79.0), 89 (46.3), 77 (25.6), 63 (13.8), 51 (11.4).

2-(Furan-2-yl)-4,5-diphenyl-1H-imidazole (8i): solid; mp 229-230 ${ }^{\circ} \mathrm{C} ;{ }_{6}{ }^{1} \mathrm{H}$ NMR $\left(300 \mathrm{MHz}\right.$, DMSO- $\left.d_{6}\right) \delta 12.85$ (br s, $1 \mathrm{H}, \mathrm{NH}), 7.81(\mathrm{~d}, 1 \mathrm{H}, J 1.6 \mathrm{~Hz}), 7.36-7.75(\mathrm{~m}, 10 \mathrm{H})$, $6.98(\mathrm{~d}, 1 \mathrm{H}, J 3.4 \mathrm{~Hz}), 6.65(\mathrm{dd}, 1 \mathrm{H}, J 3.4$ and $1.8 \mathrm{~Hz})$; ${ }^{13} \mathrm{C}$ NMR (75 MHz, DMSO- $d_{6}$ ) $\delta 148.3,145.7,143.1$, 138.6, 138.0, 129.6, 128.5, 128.3, 127.7, 111.9, 107,5; IR (Nujol) $v_{\text {max }} / \mathrm{cm}^{-1} 1602,1500,764,696$; GC-MS (IE, $70 \mathrm{eV}$ ) $\mathrm{m} / \mathrm{z}(\%) 286\left(\mathrm{M}^{+}, 100.0\right), 257$ (9.4), 165 (22.0), 143 (6.1), 128 (8.6), 89 (3.7), 77 (9.0), 63 (2.8), 51 (12.1).

4,5-Diphenyl-2-(thiophen-2-yl)-1H-imidazole (8j): solid; mp 255-256 ${ }^{\circ} \mathrm{C} ;{ }^{1}{ }^{1} \mathrm{H}$ NMR (300 MHz, DMSO- $d_{6}$ ) $\delta 12.79$ (br s, $1 \mathrm{H}, \mathrm{NH}), 7.69$ (d, $1 \mathrm{H}, J 3.5 \mathrm{~Hz}$ ), 7.25-7.51 $(\mathrm{m}, 11 \mathrm{H}), 7.15(\mathrm{dd}, 1 \mathrm{H}, J 4.7$ and $3.5 \mathrm{~Hz}) ;{ }^{13} \mathrm{C} \mathrm{NMR}(75$ MHz, DMSO- $d_{6}$ ) $\delta 124.1,126.2,126.5,127.0,127.8$, 128.1, 128.6, 130.8, 133.9, 134.7, 136.6, 141.5; IR (Nujol) $v_{\max } / \mathrm{cm}^{-1} 1594,1493,765,695$; GC-MS (IE, $70 \mathrm{eV}$ ) $\mathrm{m} / \mathrm{z}(\%) 304$ (6.77), $302\left(\mathrm{M}^{+}, 100.0\right), 165$ (39.7), 151 (8.7), 95 (7.4), 89 (5.8), 77 (6.3), 69 (6.5), 63 (4.1), 51 (4.3).

4,5-Diphenyl-2-(thiophen-3-yl)-1H-imidazole (8k): solid; mp 257-259 ${ }^{\circ} \mathrm{C} ;{ }^{1} \mathrm{H}$ NMR (300 MHz, DMSO- $d_{6}$ ) $\delta$ $12.63(\mathrm{br} \mathrm{s}, 1 \mathrm{H}, \mathrm{NH}), 8.04$ (dd, $1 \mathrm{H}, J 2.9$ and 1.3), 7.71 (dd, $1 \mathrm{H}, J 5.0$ and $1.2 \mathrm{~Hz}), 7.65(\mathrm{dd}, 1 \mathrm{H}, J 5.0$ and 2.9 $\mathrm{Hz}), 7.31-7.53(\mathrm{~m}, 10 \mathrm{H}) ;{ }^{13} \mathrm{C}$ NMR $\left(75 \mathrm{MHz}\right.$, DMSO- $\left.d_{6}\right)$ $\delta$ 142.7, 132.5, 128.4, 127.7,127.0, 125.9, 121.8; IR (Nujol) $v_{\text {max }} / \mathrm{cm}^{-1} 1593,1493,765,697$; GC-MS (IE, 70 eV) $\mathrm{m} / \mathrm{z}(\%) 304$ (6.64), $302\left(\mathrm{M}^{+}, 100.0\right), 165$ (46.6), 151 (8.9), 89 (10.3), 77 (6.5), 63 (5.2), 51 (4.2); HRMS (ESI, w/ $\mathrm{H}^{+}$) calcd. 303.09505, found 303.09518.

4,5-Bis(4-methoxyphenyl)-2-(thiophen-3-yl)lH-imidazole (8l): solid; mp 199-201 ${ }^{\circ} \mathrm{C} ;{ }^{7}{ }^{1} \mathrm{H}$ NMR $\left(400 \mathrm{MHz}, \mathrm{DMSO}-d_{6}\right) \delta 12.35$ (br s, $\left.1 \mathrm{H}, \mathrm{NH}\right), 7.97$ (dd, 1H, $J 2.9$ and $1.5 \mathrm{~Hz}), 7.68(\mathrm{dd}, 1 \mathrm{H}, J 4.8$ and $1.1 \mathrm{~Hz}), 7.62(\mathrm{dd}, 1 \mathrm{H}, J 5.5$ and $2.9 \mathrm{~Hz}), 6.80-7.50(\mathrm{~m}, 8 \mathrm{H})$, $3.75(\mathrm{~s}, 3 \mathrm{H}), 3.79(\mathrm{~s}, 3 \mathrm{H}) ;{ }^{13} \mathrm{C}$ NMR $\left(100 \mathrm{MHz}\right.$, DMSO- $\left.d_{6}\right)$ $\delta 148.3,143.4,137.7,134.7,131.8,131.2,130.6,130.4$, 129.2, 128.7, 128.4, 128.3, 128.1, 127.1, 126.8, 122.6, 119.4; IR (Nujol) $v_{\max } / \mathrm{cm}^{-1} 3391,1655,1600,1573,1508$, 1259, 1163, 842, 832; GC-MS (IE, $70 \mathrm{eV}$ ) $\mathrm{m} / \mathrm{z}$ (\%) 362 $\left(\mathrm{M}^{+}, 100.0\right), 347$ (28.4), 275 (4.1), 181 (5.7).

4,5-Bis(4-fluorophenyl)-2-phenyl-1H-imidazole (8m): solid; mp 255-257 ${ }^{\circ} \mathrm{C} ;{ }^{8}{ }^{1} \mathrm{H}$ NMR (400 MHz, DMSO- $d_{6}$ ) $\delta 12.67$ (br s, $1 \mathrm{H}, \mathrm{NH}), 8.07$ (dd, $2 \mathrm{H}, J 8.4$ and $1.1 \mathrm{~Hz}$ ), 7.50-7.60 (m, 4H), $7.48(\mathrm{t}, 2 \mathrm{H}, J 7.5 \mathrm{~Hz}), 7.38(\mathrm{t}, 1 \mathrm{H}$, $J 7.3 \mathrm{~Hz}), 7.29(\mathrm{t}, 2 \mathrm{H}, J 8.8 \mathrm{~Hz}), 7.14(\mathrm{t}, 2 \mathrm{H}, J 8.8 \mathrm{~Hz})$; ${ }^{13} \mathrm{C}$ NMR (100 MHz, DMSO- $\left.d_{6}\right) \delta 161.5\left(\mathrm{~d},{ }^{1} J_{C F} 245.7 \mathrm{~Hz}\right)$, $160.9\left(\mathrm{~d},{ }^{1} J_{C F} 243.4 \mathrm{~Hz}\right), 145.4,136.1,131.4\left(\mathrm{~d},{ }^{4} J_{C F} 3.1 \mathrm{~Hz}\right)$, $130.4\left(\mathrm{~d},{ }^{3} J_{C F} 8.4 \mathrm{~Hz}\right), 130.1,128.7\left(\mathrm{~d},{ }^{3} J_{C F} 7.6 \mathrm{~Hz}\right), 128.5$, 128.1, 128.0, $127.2\left(\mathrm{~d},{ }^{4} J_{C F} 3.1 \mathrm{~Hz}\right), 126.9,125.0,115.5$ $\left(\mathrm{d},{ }^{2} J_{C F} 21.4 \mathrm{~Hz}\right), 114.9\left(\mathrm{~d},{ }^{2} J_{C F} 21.4 \mathrm{~Hz}\right)$; IR (Nujol) $v_{\text {max }} / \mathrm{cm}^{-1} 1606,1590,1537,1514,1595,1226,1156,835$; GC-MS (IE, $70 \mathrm{eV}) \mathrm{m} / \mathrm{z}$ (\%) $332\left(\mathrm{M}^{+}, 100.0\right), 201$ (44.1), 89 (9.6), 77 (3.0), 63 (4.6), 51 (2.2), 39 (2.0).

4-[4,5-Bis(4-fluorophenyl)-1H-imidazol-2-yl)] benzonitrile (8n): solid; mp 272-274 ${ }^{\circ} \mathrm{C} ;{ }^{1} \mathrm{H}$ NMR $\left(400 \mathrm{MHz}, \mathrm{DMSO}-d_{6}\right) \delta 12.98$ (br s, $\left.1 \mathrm{H}, \mathrm{NH}\right), 8.23(\mathrm{~d}, 2 \mathrm{H}$, $J 8.3 \mathrm{~Hz}), 7.93(\mathrm{~d}, 2 \mathrm{H}, J 8.3 \mathrm{~Hz}), 7.55(\mathrm{~d}, 2 \mathrm{H}, J 8.8 \mathrm{~Hz})$, $7.54(\mathrm{~d}, 2 \mathrm{H}, J 8.8 \mathrm{~Hz}), 7.00-7.40(\mathrm{~m}, 4 \mathrm{H}) ;{ }^{13} \mathrm{C} \mathrm{NMR}$ $\left(100 \mathrm{MHz}, \mathrm{DMSO}-d_{6}\right) \delta 143.5,134.0,132.6,128.7,128.0$, 125.4, 125.1, 118.6, 110.0; IR (Nujol) $v_{\max } / \mathrm{cm}^{-1} 2229,1608$, 1516, 1497, 1223, 1161, 847, 837; GC-MS (IE, $70 \mathrm{eV}$ ) $\mathrm{m} / \mathrm{z}(\%) 357\left(\mathrm{M}^{+}, 100.0\right), 201$ (42.5), 107 (13.3); HRMS (ESI, $\left.\mathrm{w} / \mathrm{H}^{+}\right)$calcd. 358.11522, found 358.11503 .

4,5-Bis(4-fluorophenyl)-2-(furan-2-yl)-1H-imidazole (8o): solid; mp $223-225^{\circ} \mathrm{C} ;{ }^{1} \mathrm{H}$ NMR $\left(400 \mathrm{MHz}\right.$, DMSO- $\left.d_{6}\right)$ $\delta 12.81(\mathrm{br} \mathrm{s}, 1 \mathrm{H}, \mathrm{NH}), 7.79(\mathrm{dd}, 1 \mathrm{H}, J 1.8$ and $0.7 \mathrm{~Hz})$, 7.42-7.58 (m, 4H), $7.27(\mathrm{t}, 2 \mathrm{H}, J 9.0 \mathrm{~Hz}), 7.14(\mathrm{t}, 2 \mathrm{H}$, $J 9.0 \mathrm{~Hz}), 6.96(\mathrm{dd}, 1 \mathrm{H}, J 3.3$ and $0.7 \mathrm{~Hz}), 6.64(\mathrm{dd}, 1 \mathrm{H}$, $J 3.3$ and $1.8 \mathrm{~Hz}$ ); ${ }^{13} \mathrm{C}$ NMR (100 MHz, DMSO- $\left.d_{6}\right) \delta$ $161.6\left(\mathrm{~d},{ }^{1} J_{C F} 244.1 \mathrm{~Hz}\right), 161.0\left(\mathrm{~d},{ }^{1} J_{C F} 241.9 \mathrm{~Hz}\right), 145.5$, $143.0,138.4,136.8,136.0,130.4\left(\mathrm{~d},{ }^{3} J_{C F} 8.4 \mathrm{~Hz}\right), 128.9(\mathrm{~d}$, $\left.{ }^{3} J_{C F} 8.4 \mathrm{~Hz}\right), 127.0\left(\mathrm{~d},{ }^{4} J_{C F} 3.1 \mathrm{~Hz}\right), 126.3,115.6(\mathrm{~d}$, $\left.{ }^{2} J_{C F} 22.1 \mathrm{~Hz}\right), 115.0\left(\mathrm{~d},{ }^{2} J_{C F} 21.4 \mathrm{~Hz}\right), 111.7,107.4$; IR (Nujol) $v_{\text {max }} / \mathrm{cm}^{-1} 1606,1529,1514,1496,1228,1158$, 836, 738; GC-MS (IE, $70 \mathrm{eV}$ ) $\mathrm{m} / \mathrm{z}$ (\%) $322\left(\mathrm{M}^{+}, 100.0\right.$ ), 293 (11.8), 201 (18.8), 107 (3.9); HRMS (ESI, w/H $\mathrm{H}^{+}$) calcd. 323.09905, found 323.09912.

4,5-Bis(4-fluorophenyl)- 2-(thiophen-3-yl)1H-imidazole (8p): solid; mp 255-256 ${ }^{\circ} \mathrm{C} ;{ }^{1} \mathrm{H}$ NMR 
(400 MHz, DMSO- $\left.d_{6}\right) \delta 8.17$ (dd, $1 \mathrm{H}, J 2.9$ and $1.5 \mathrm{~Hz}$ ), $7.76(\mathrm{dd}, 1 \mathrm{H}, J 5.1$ and $1.5 \mathrm{~Hz}), 7.69(\mathrm{dd}, 1 \mathrm{H}, J 5.1$ and $2.9 \mathrm{~Hz}), 7.54(\mathrm{dd}, 4 \mathrm{H}, J 9.2$ e $5.5 \mathrm{~Hz} \mathrm{~Hz}), 7.24(\mathrm{t}, 4 \mathrm{H}$, $J 8.8 \mathrm{~Hz}) ;{ }^{13} \mathrm{C}$ NMR (100 MHz, DMSO- $\left.d_{6}\right) \delta 166.6(\mathrm{~d}$, $\left.{ }^{1} J_{C F} 248.0 \mathrm{~Hz}\right), 166.0\left(\mathrm{~d},{ }^{1} J_{C F} 255.6 \mathrm{~Hz}\right), 162.6,160.2$, $141.9,132.8,132.7,132.6,129.8\left(\mathrm{~d},{ }^{3} J_{C F} 8.4 \mathrm{~Hz}\right), 128.1$, $127.1,152.7,123.2,116.5\left(\mathrm{~d},{ }^{2} J_{C F} 22.1 \mathrm{~Hz}\right), 115.3(\mathrm{~d}$, ${ }^{2} J_{C F} 21.4 \mathrm{~Hz}$ ); IR (Nujol) $v_{\max } / \mathrm{cm}^{-1} 3467,1650,1598$, 1501, 1227, 1156, 835; GC-MS (IE, $70 \mathrm{eV}$ ) $\mathrm{m} / \mathrm{z}$ (\%) 338 $\left(\mathrm{M}^{+}, 100.0\right), 201$ (43.7), 107 (11.4), 95 (9.6); HRMS $\left(\right.$ ESI, w/H $\mathrm{H}^{+}$) calcd. 339.07620, found 339.07639.

2,4,5-Triphenyl-1,3-oxazole (10a): solid; mp $111-113{ }^{\circ} \mathrm{C} ;{ }^{1}{ }^{1} \mathrm{H}$ NMR $\left(200 \mathrm{MHz}\right.$, DMSO- $\left.d_{6}\right) \delta 8.4-8.0$ $(\mathrm{m}, 2 \mathrm{H}), 7.3-7.15(\mathrm{~m}, 13 \mathrm{H}) ;{ }^{13} \mathrm{C} \mathrm{NMR}\left(50 \mathrm{MHz}, \mathrm{DMSO}-d_{6}\right)$ $\delta$ 159.9, 145.7, 136.5, 132.3, 131.3, 129.7, 129.5, 129.2, 129.0, 128.6, 128.1, 127.0, 126.6; IR (Nujol) $v_{\max } / \mathrm{cm}^{-1}$ 3060, 2000-1700, 1600, 1590, 1500, 1490, 700, 690; GC-MS (IE, $70 \mathrm{eV}$ ) $\mathrm{m} / \mathrm{z}$ (\%) $297\left(\mathrm{M}^{+}, 100.0\right), 269$ (28.7), 165 (92.9). 105 (9.5), 89 (27.7), 77 (22.7), 63 (14.1), 51 (10.4)

2,4,5-Tris(4-fluorophenyl)-1,3-oxazole (10b): solid; mp $154-157^{\circ} \mathrm{C} ;{ }^{1} \mathrm{H}$ NMR $\left(200 \mathrm{MHz}\right.$, DMSO- $\left.d_{6}\right) \delta 8.3-7.9$ $(\mathrm{m}, 2 \mathrm{H}), 7.8-7.1(\mathrm{~m}, 10 \mathrm{H}) ;{ }^{13} \mathrm{C}$ NMR $\left(50 \mathrm{MHz}, \mathrm{DMSO}-d_{6}\right)$ $\delta 164.2,162.9,162.6,116.9,116.8,166.4,130.4,129.6$,
129.3, 128.7, 125.1, 123.7; IR (Nujol) $v_{\max } / \mathrm{cm}^{-1} 3060$, 2100-1700, 1600, 1520, 1500, 1200, 820; GC-MS (IE, $70 \mathrm{eV}) \mathrm{m} / \mathrm{z}(\%) 351\left(\mathrm{M}^{+}, 86.6\right), 323$ (18.6), 201 (100.0), 123 (10.5), 107 (28.9), 95 (19.3), 81 (4.4), 51(1.1); HRMS (ESI, w/H $\mathrm{H}^{+}$calcd. 352.09922, found 352.0979.

\section{References}

1. Sangshetti, J. N.; Kokare, N. D.; Kotharkar, S. A.; Shinde, D. B.; Monatsh. Chem. 2008, 139, 125.

2. Kidwai, M.; Mothsra, P.; Bansal, V.; Somvanshi, R. K.; Ethayathulla, A. S.; Dey, S.; Singh,T. P.; J. Mol. Catal. A: Chem. 2007, 265, 177.

3. Mohammadi, A. A.; Mivechi, M.; Kefayati, H.; Monatsh. Chem. 2008, 139, 935.

4. Zang, H.; Su, Q.; Yingming, M.; Cheng, B.-W.; Jun, S.; Ultrason. Sonochem. 2010, 17, 749.

5. Samai, S.; Nandi, G. C.; Singh, P.; Singh, M. S.; Tetrahedron 2009, 65, 10155.

6. Bahrami, K.; Khodaei, M. M.; Nejati, A.; Monatsh. Chem. 2011, 142, 159.

7. Seko, N.; Yoshino, K.; Yokota, K.; Tsukamoto, G.; Chem. Pharm. Bull. 1991, 39, 651.

8. Kamijo, S.; Yamamoto, Y.; Chem. Asian J. 2007, 2, 568.

9. Ramirez, T. A.; Zhao, B.; Shi, Y.; Tetrahedron Lett. 2010, 51, 1822.

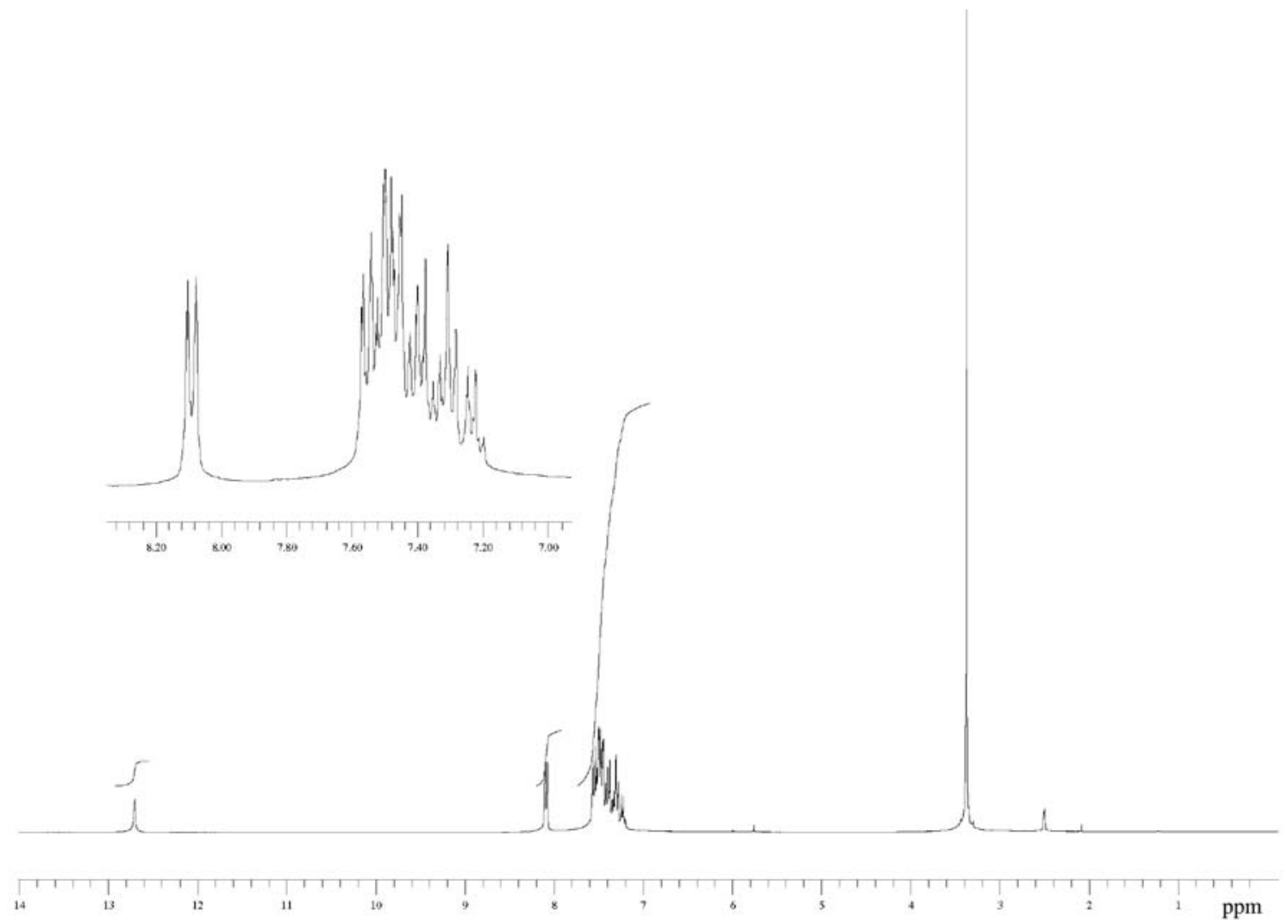

Figure S1. ${ }^{1} \mathrm{H}$ NMR spectrum (300 MHz, DMSO- $d_{6}$ ) of compound 2,4,5-triphenyl- $1 H$-imidazole (8a). 


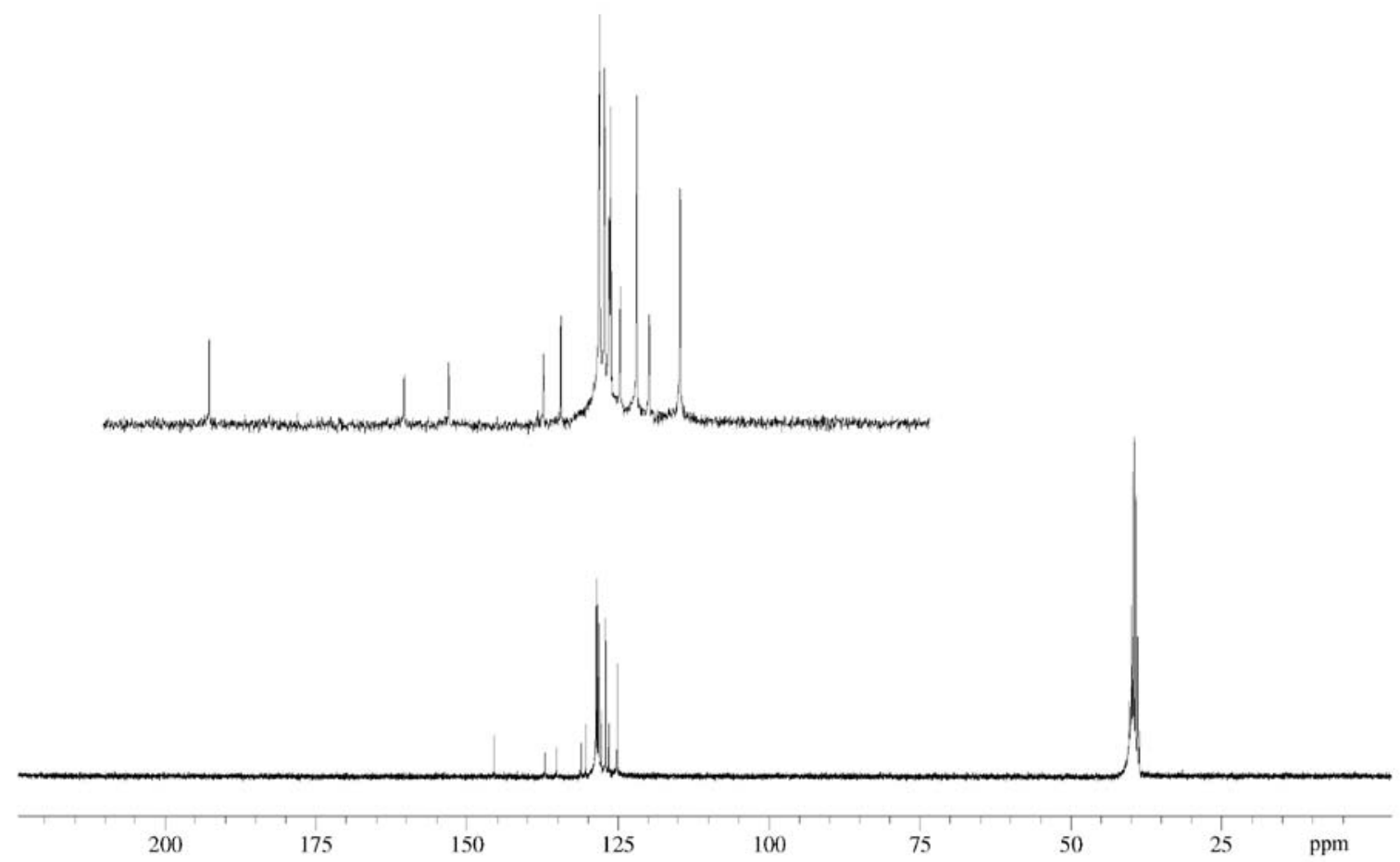

Figure S2. ${ }^{13} \mathrm{C}$ NMR spectrum (75 MHz, DMSO- $d_{6}$ ) of compound 2,4,5-triphenyl-1H-imidazole (8a).

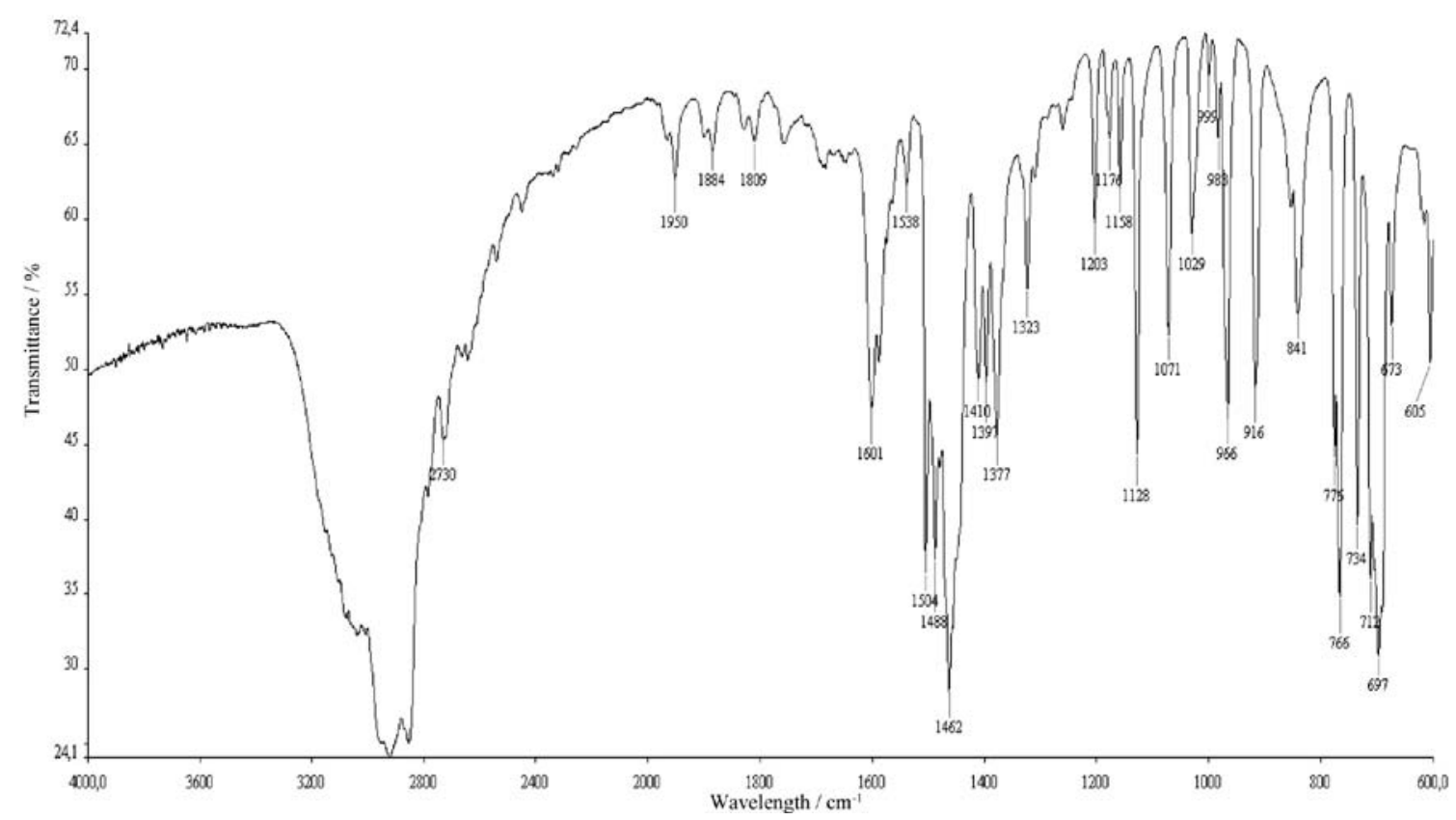

Figure S3. IR spectrum (Nujol) of compound 2,4,5-triphenyl-1H-imidazole (8a). 


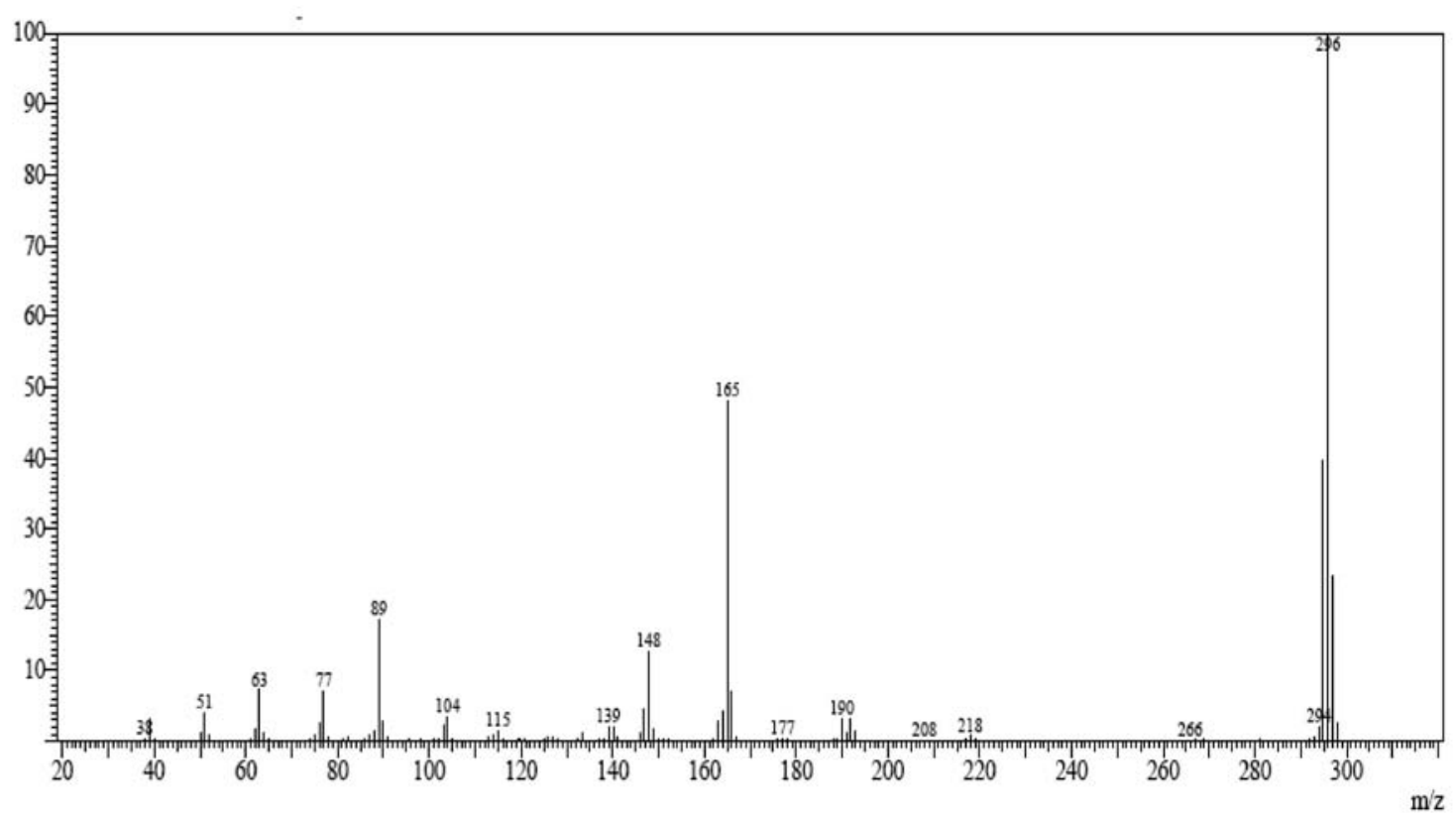

Figure S4. Mass spectrum (70 eV) of compound 2,4,5-triphenyl- $1 H$-imidazole (8a).

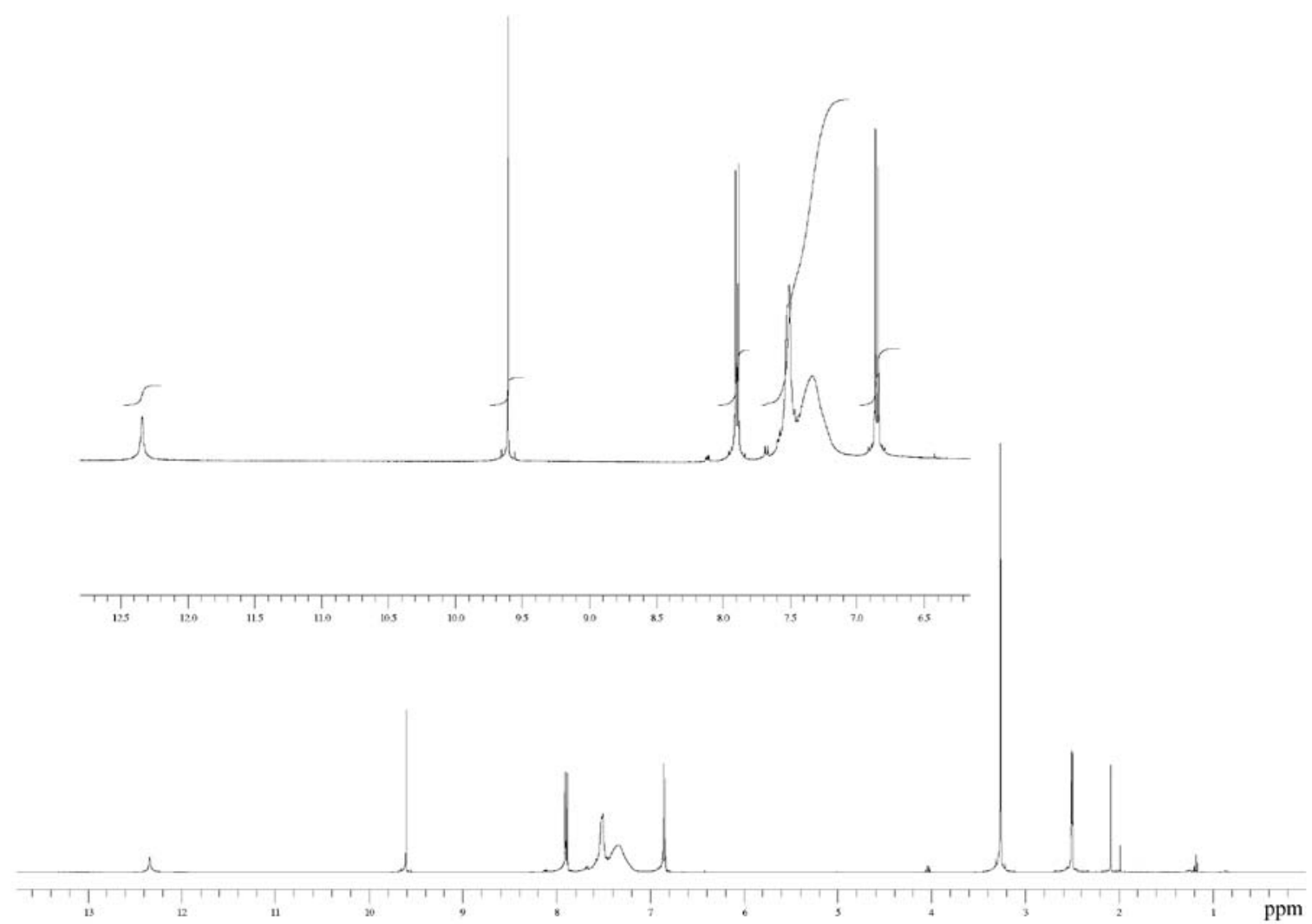

Figure S5. ${ }^{1} \mathrm{H}$ NMR spectrum (400 MHz, DMSO- $d_{6}$ ) of compound 4-(4,5-diphenyl-1H-imidazol-2-yl)phenol (8b). 


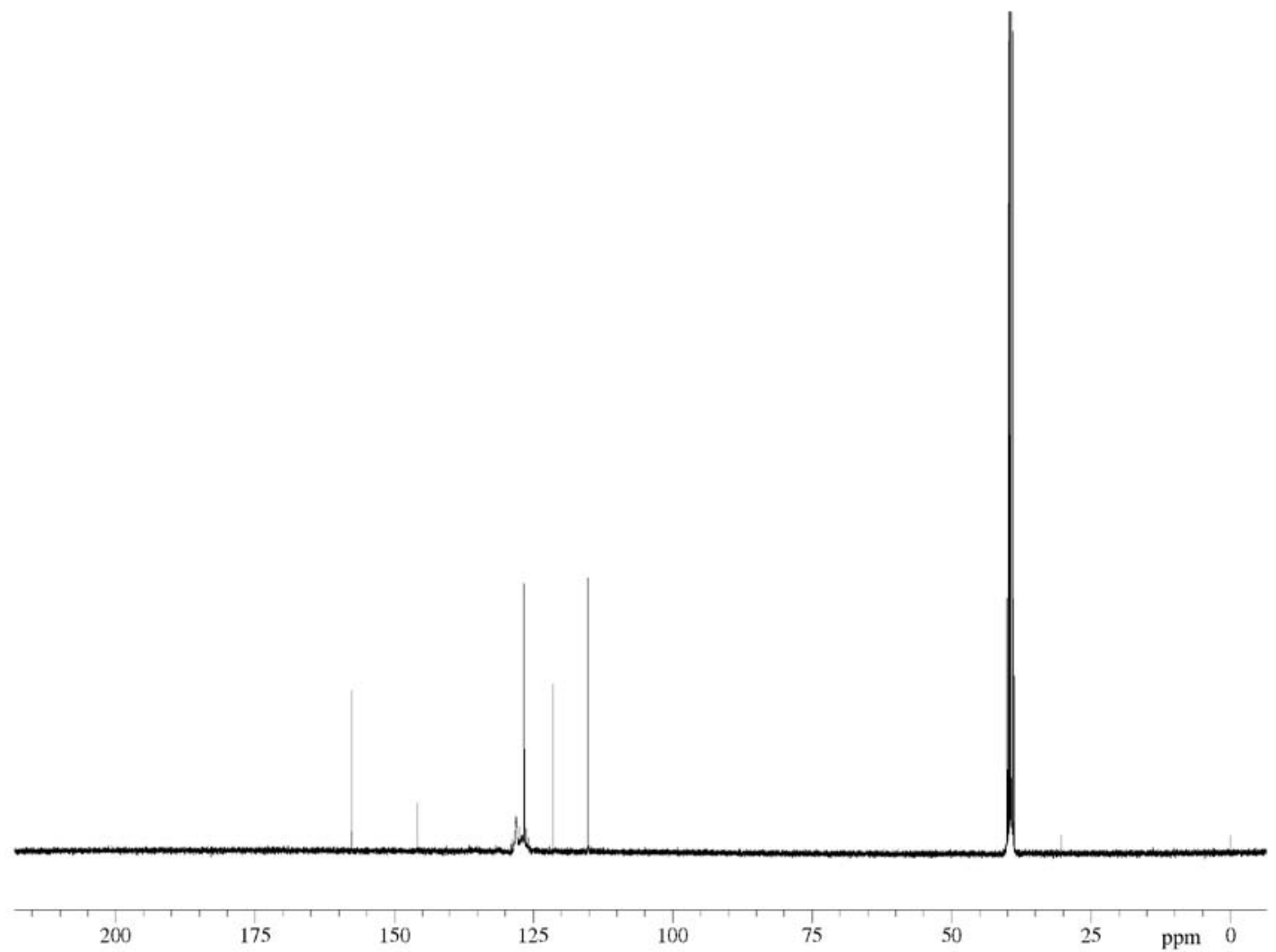

Figure S6. ${ }^{13} \mathrm{C}$ NMR spectrum (100 MHz, DMSO- $d_{6}$ ) of compound 4-(4,5-diphenyl-1H-imidazol-2-yl)phenol (8b).

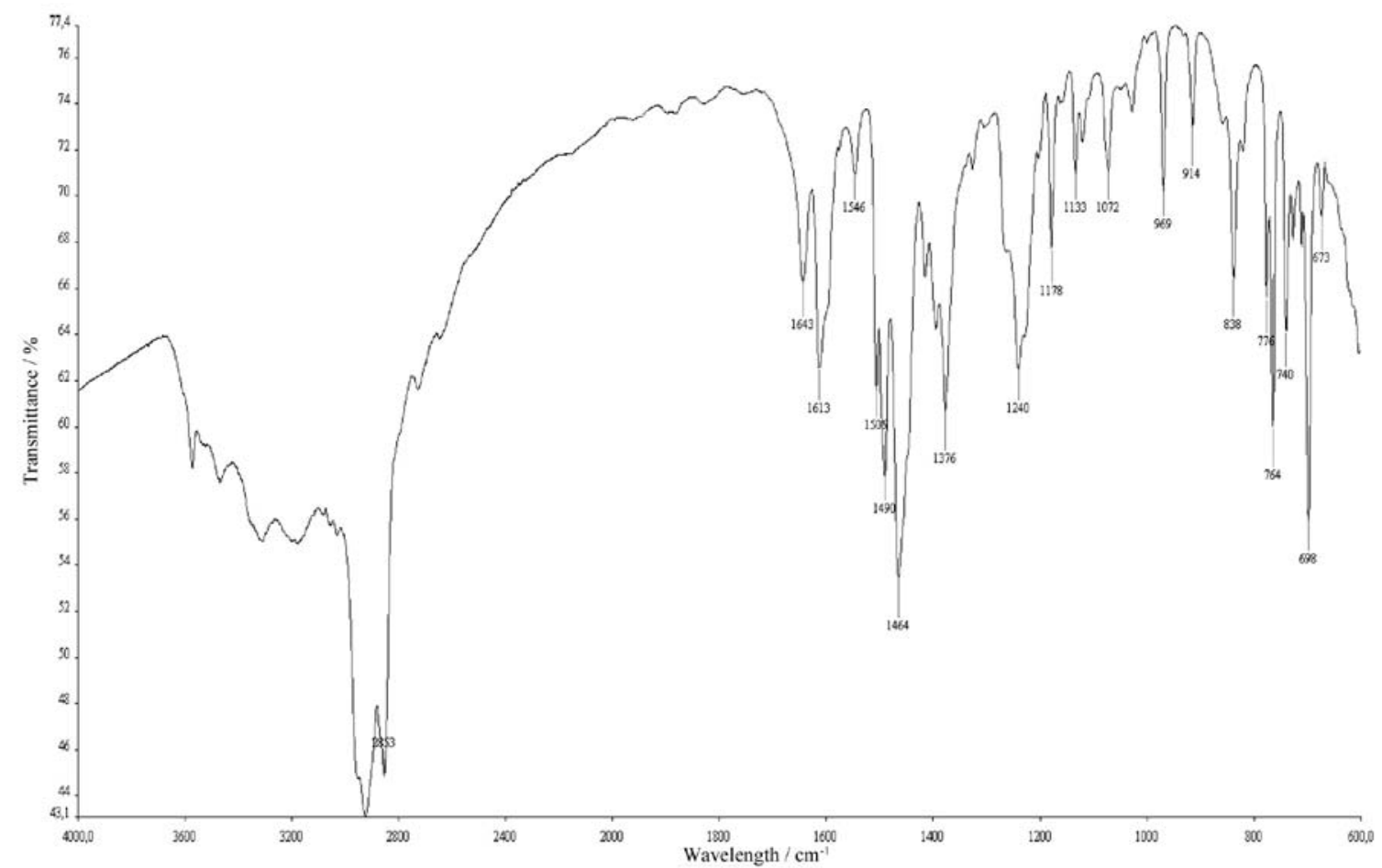

Figure S7. IR spectrum (Nujol) of compound 4-(4,5-diphenyl-1H-imidazol-2-yl)phenol (8b). 


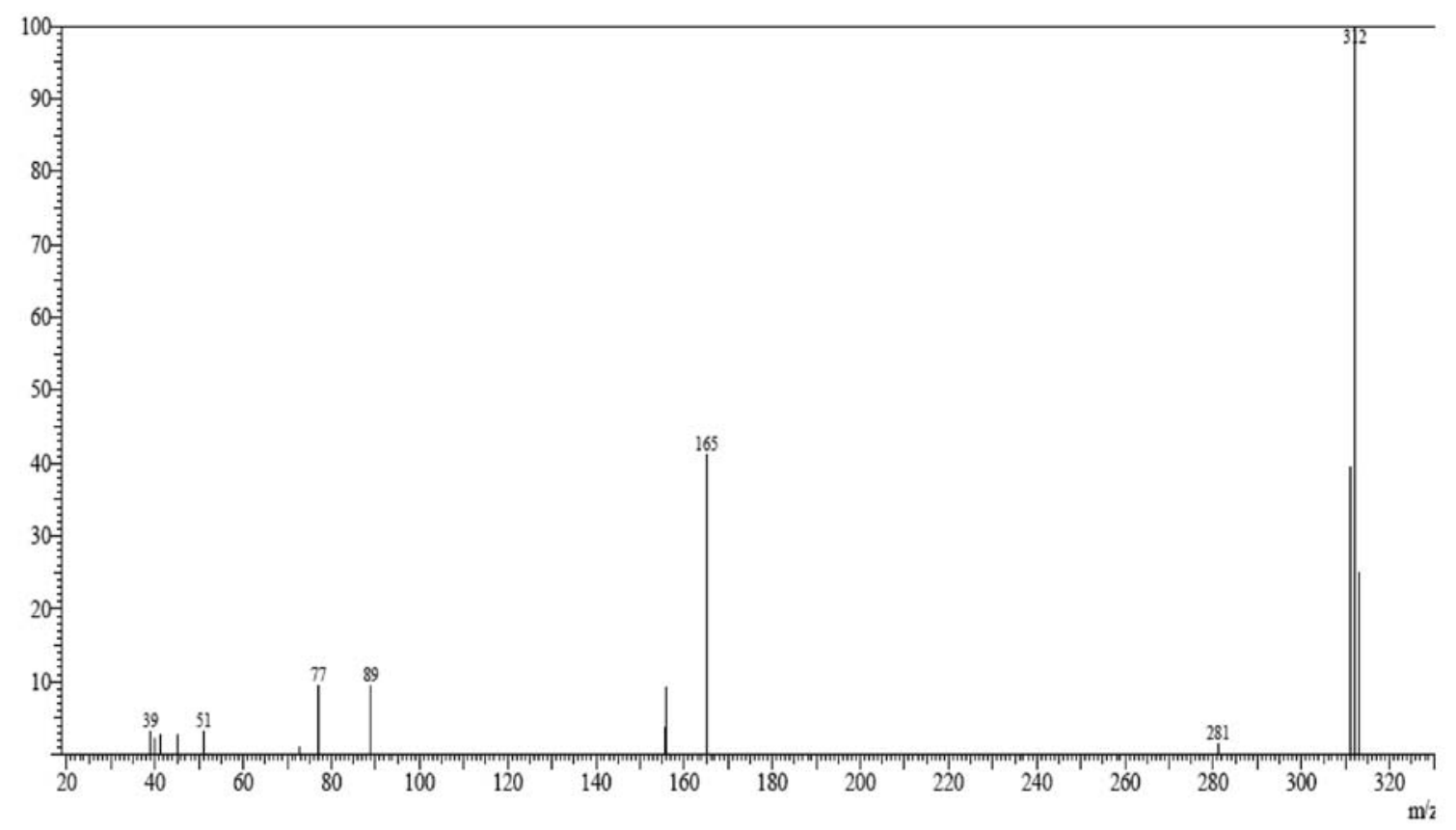

Figure S8. Mass spectrum (70 eV) of compound 4-(4,5-diphenyl-1H-imidazol-2-yl)phenol (8b).

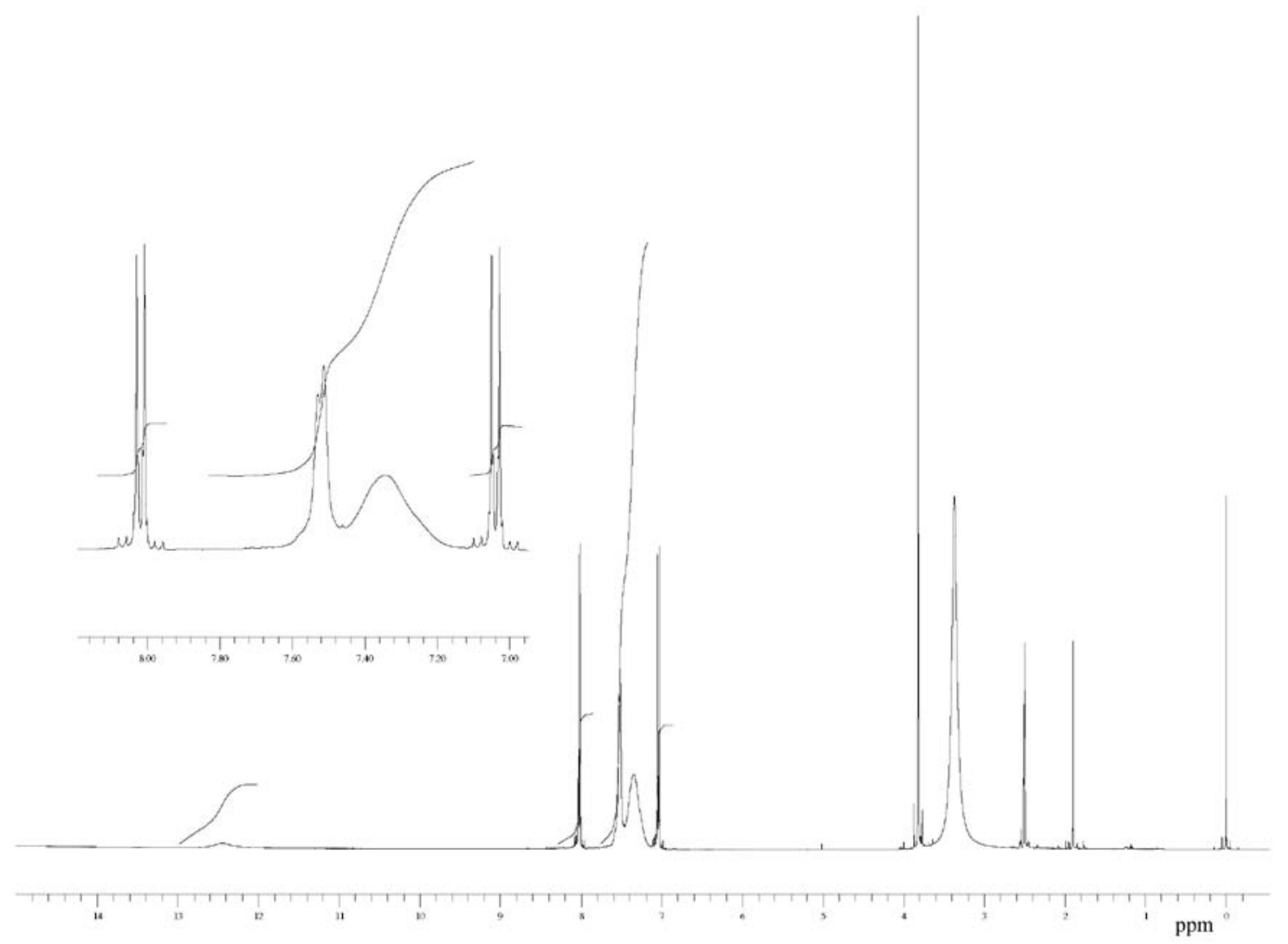

Figure S9. ${ }^{1} \mathrm{H}$ NMR spectrum (400 MHz, DMSO- $d_{6}$ ) of compound 2-(4-methoxyphenyl)-4,5-diphenyl-1H-imidazole (8c). 


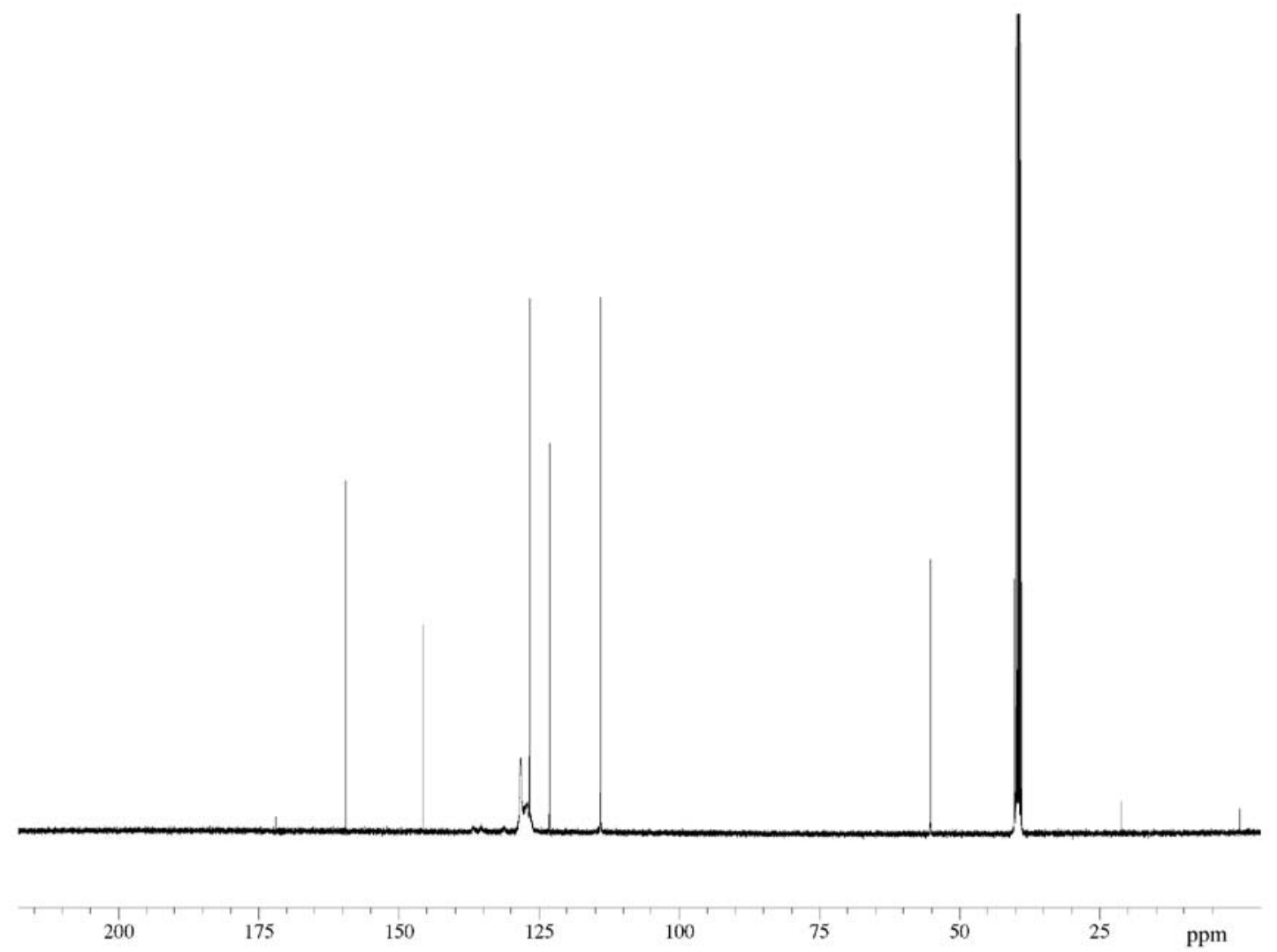

Figure S10. ${ }^{13} \mathrm{C}$ NMR spectrum (100 MHz, DMSO- $\left.d_{6}\right)$ of compound 2-(4-methoxyphenyl)-4,5-diphenyl-1H-imidazole (8c).

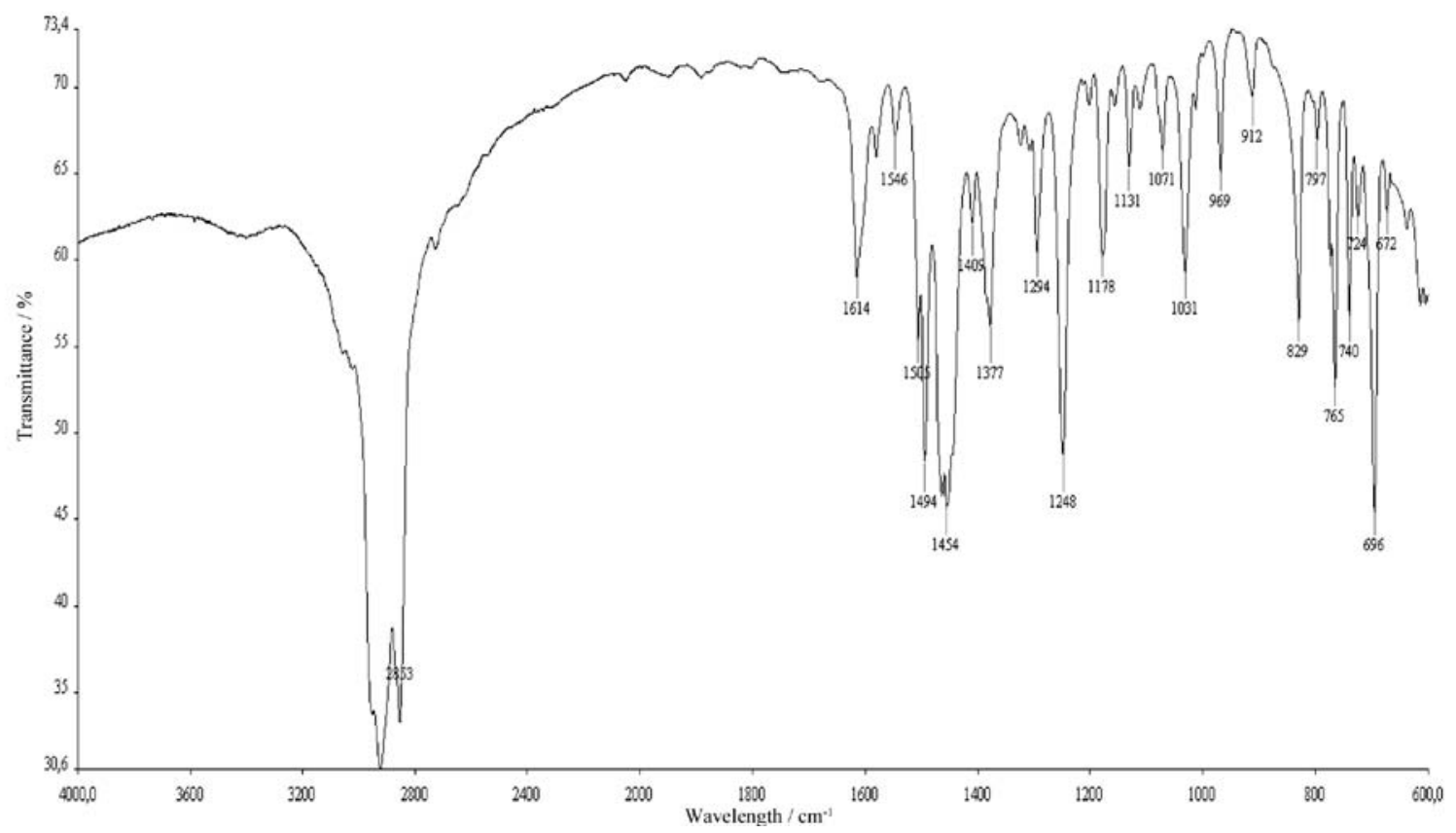

Figure S11. IR spectrum (Nujol) of compound 2-(4-methoxyphenyl)-4,5-diphenyl-1H-imidazole (8c). 


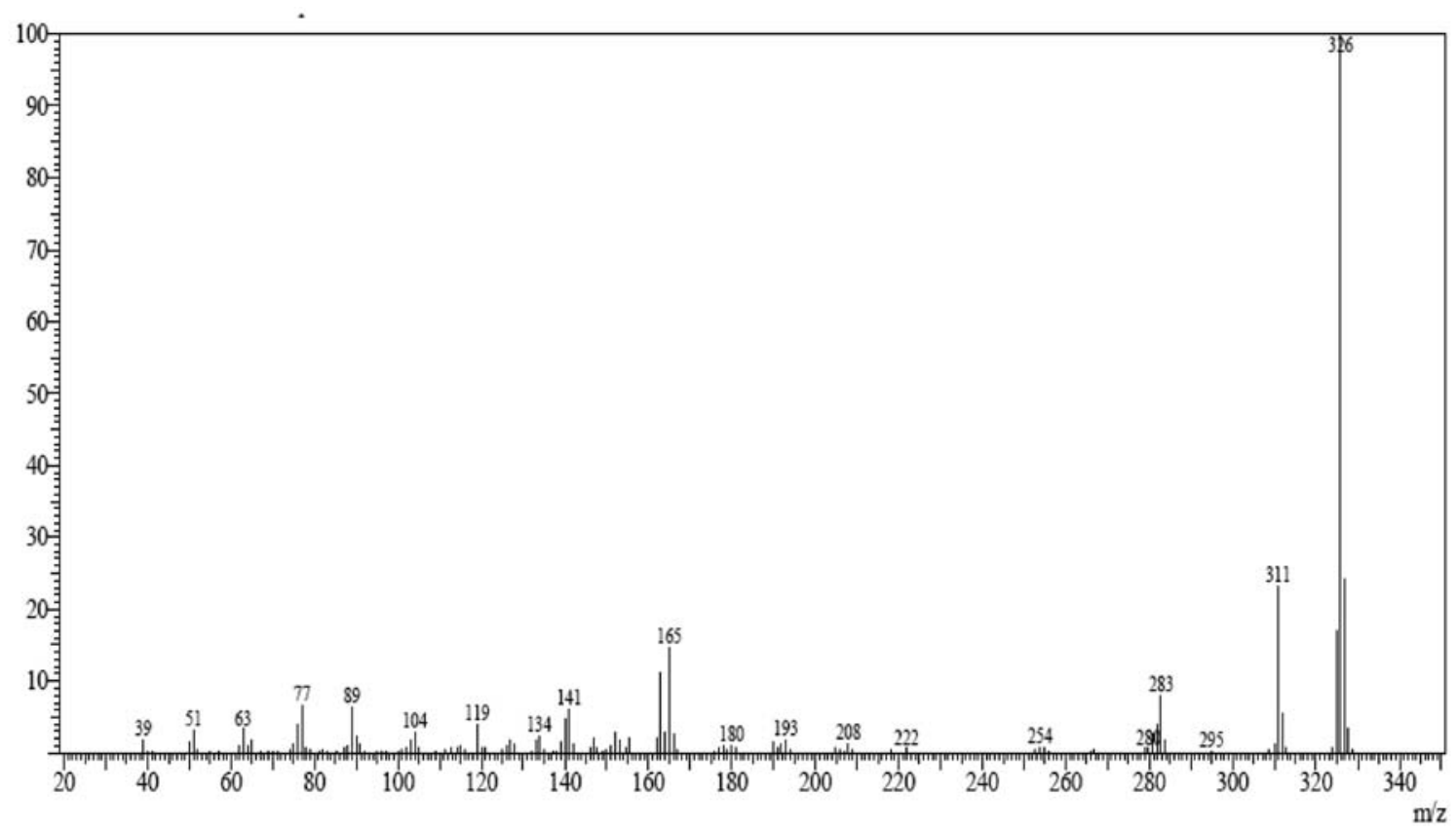

Figure S12. Mass spectrum (70 eV) of compound 2-(4-methoxyphenyl)-4,5-diphenyl-1H-imidazole (8c).

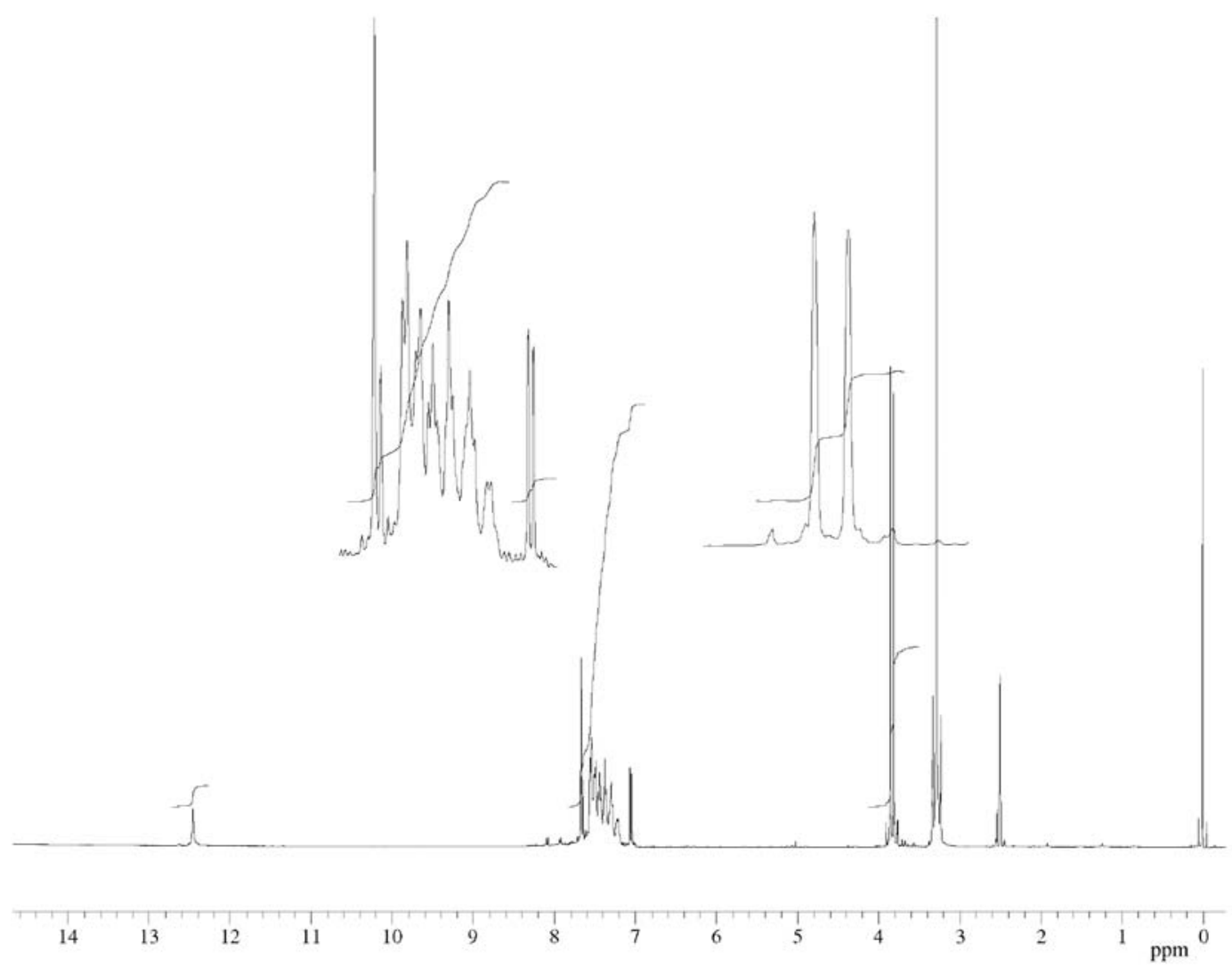

Figure S13. ${ }^{1} \mathrm{H}$ NMR spectrum (400 MHz, DMSO- $d_{6}$ ) of compound 2-(3,4-dimethoxyphenyl)-4,5-diphenyl-1 $H$-imidazole (8d). 

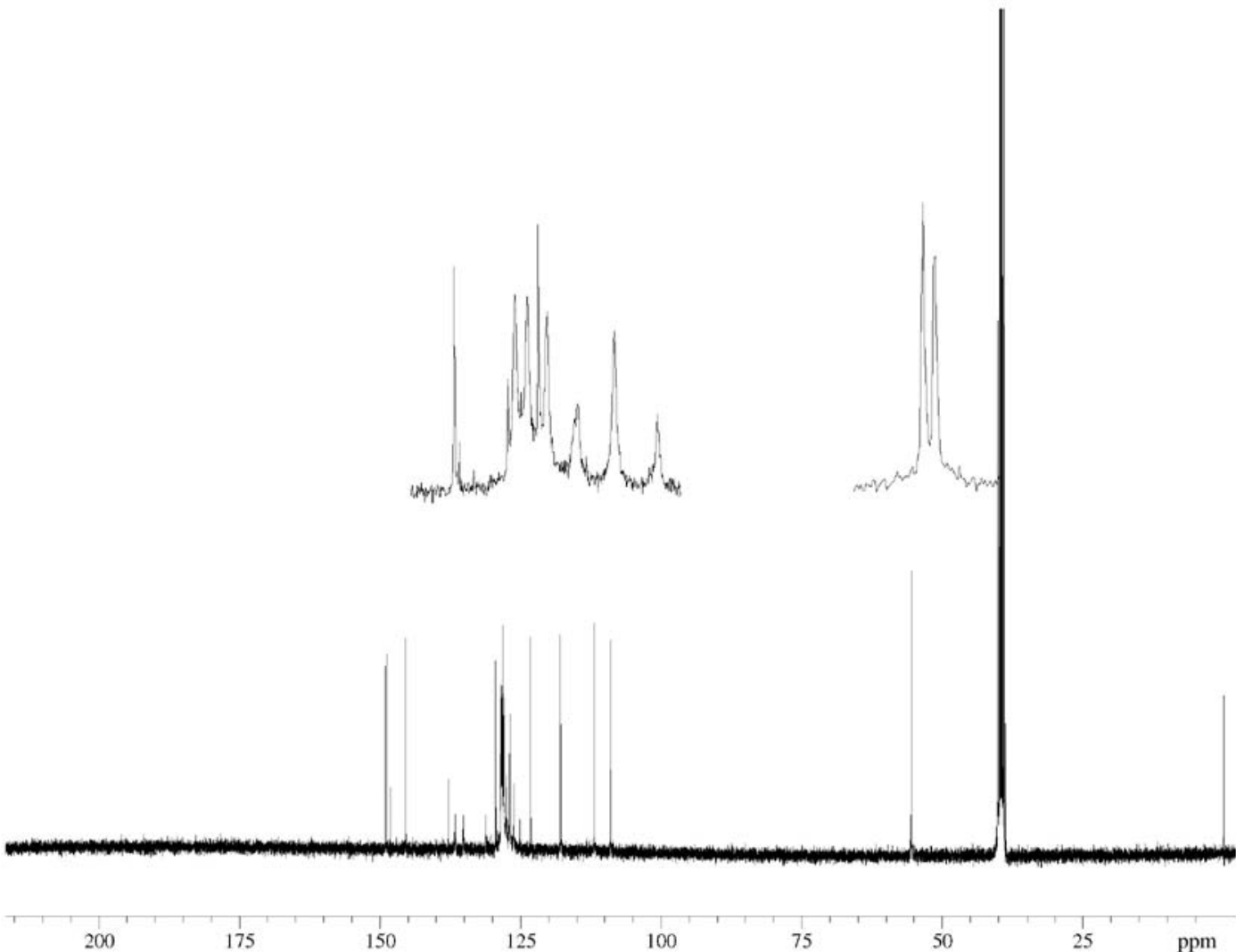

Figure S14. ${ }^{13} \mathrm{C}$ NMR spectrum (100 MHz, DMSO- $d_{6}$ ) of compound 2-(3,4-dimethoxyphenyl)-4,5-diphenyl-1 $H$-imidazole (8d).

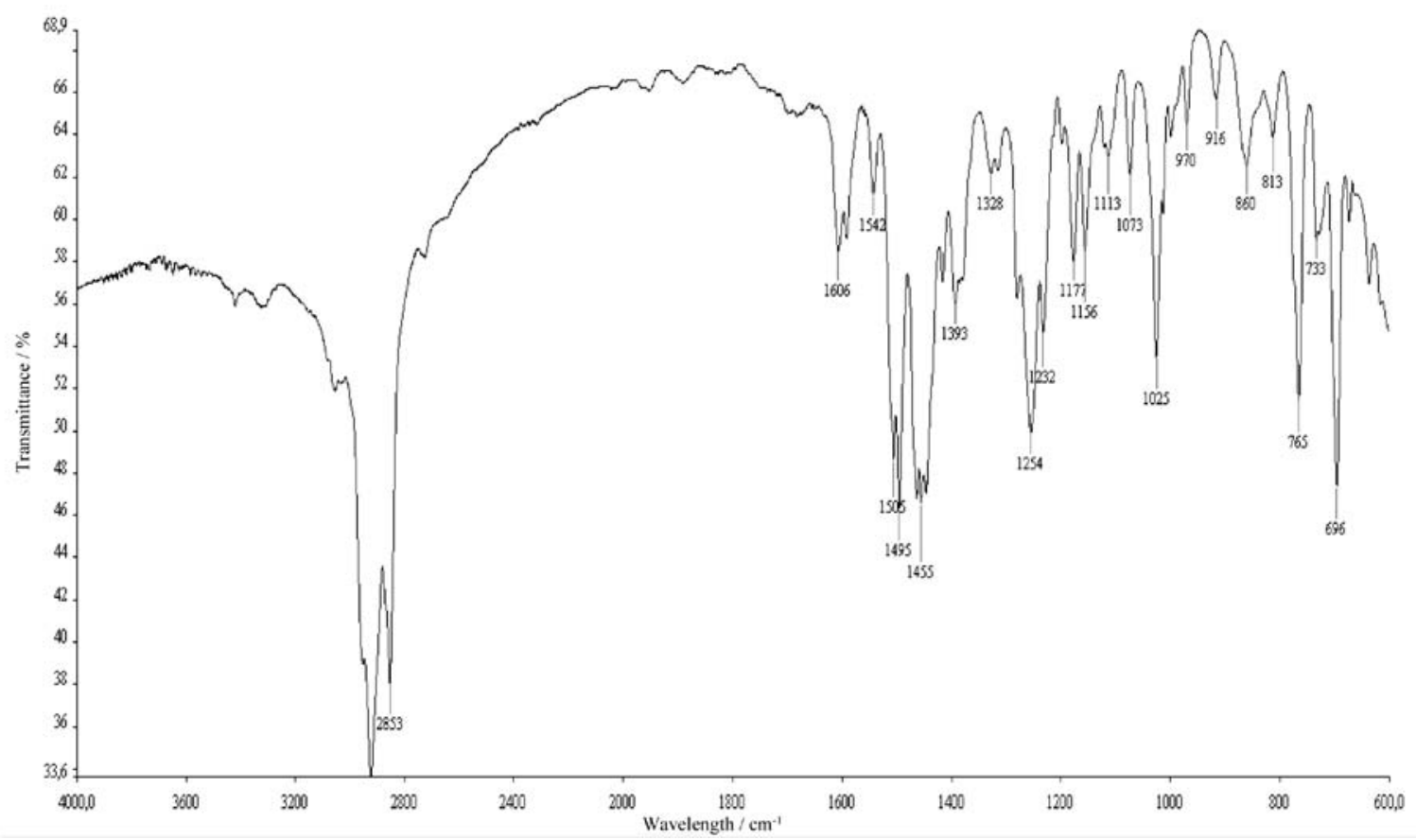

Figure S15. IR spectrum (Nujol) of compound 2-(3,4-dimethoxyphenyl)-4,5-diphenyl-1H-imidazole (8d). 


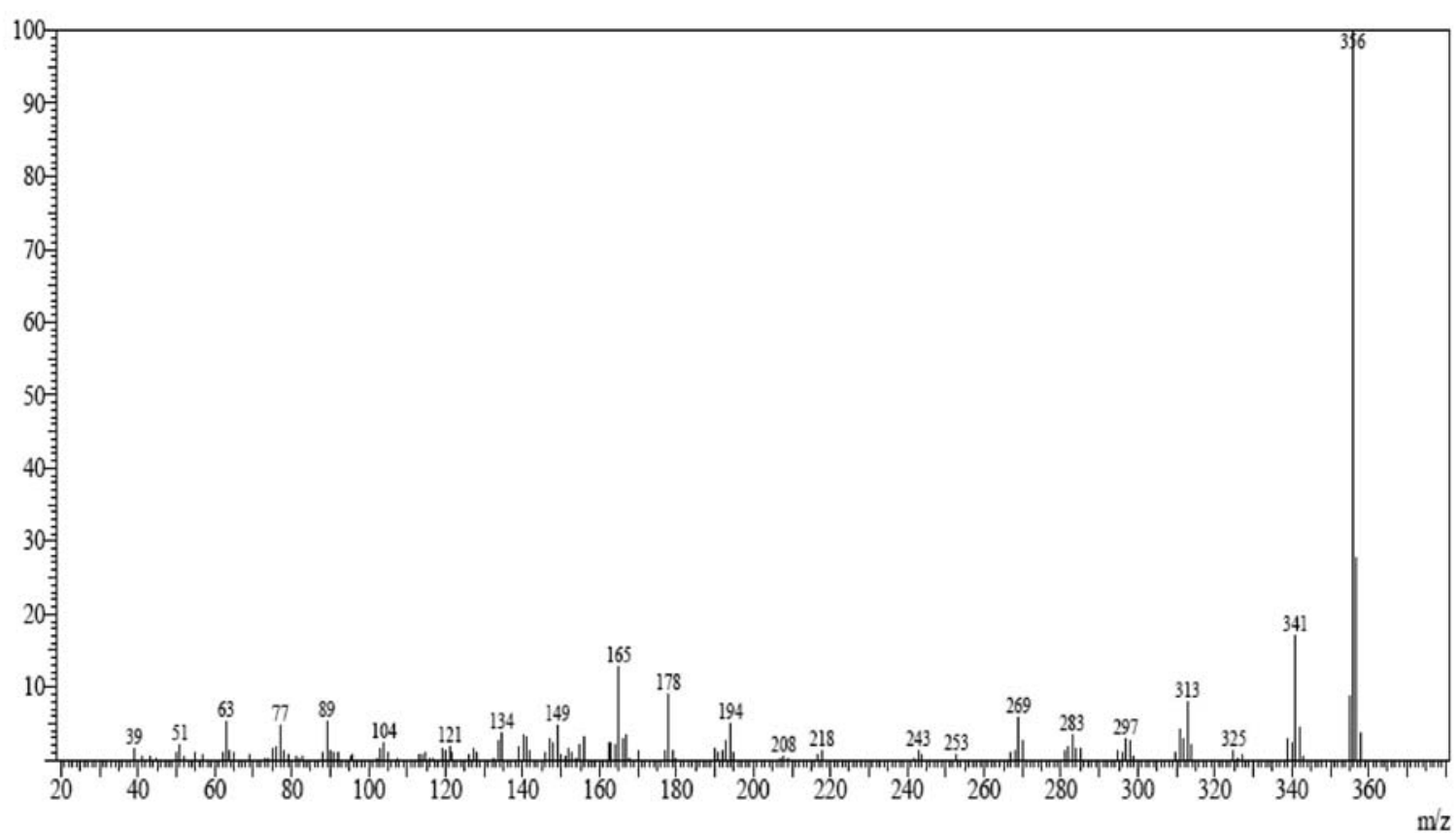

Figure S16. Mass spectrum (70 eV) of compound 2-(3,4-dimethoxyphenyl)-4,5-diphenyl- $1 H$-imidazole (8d).

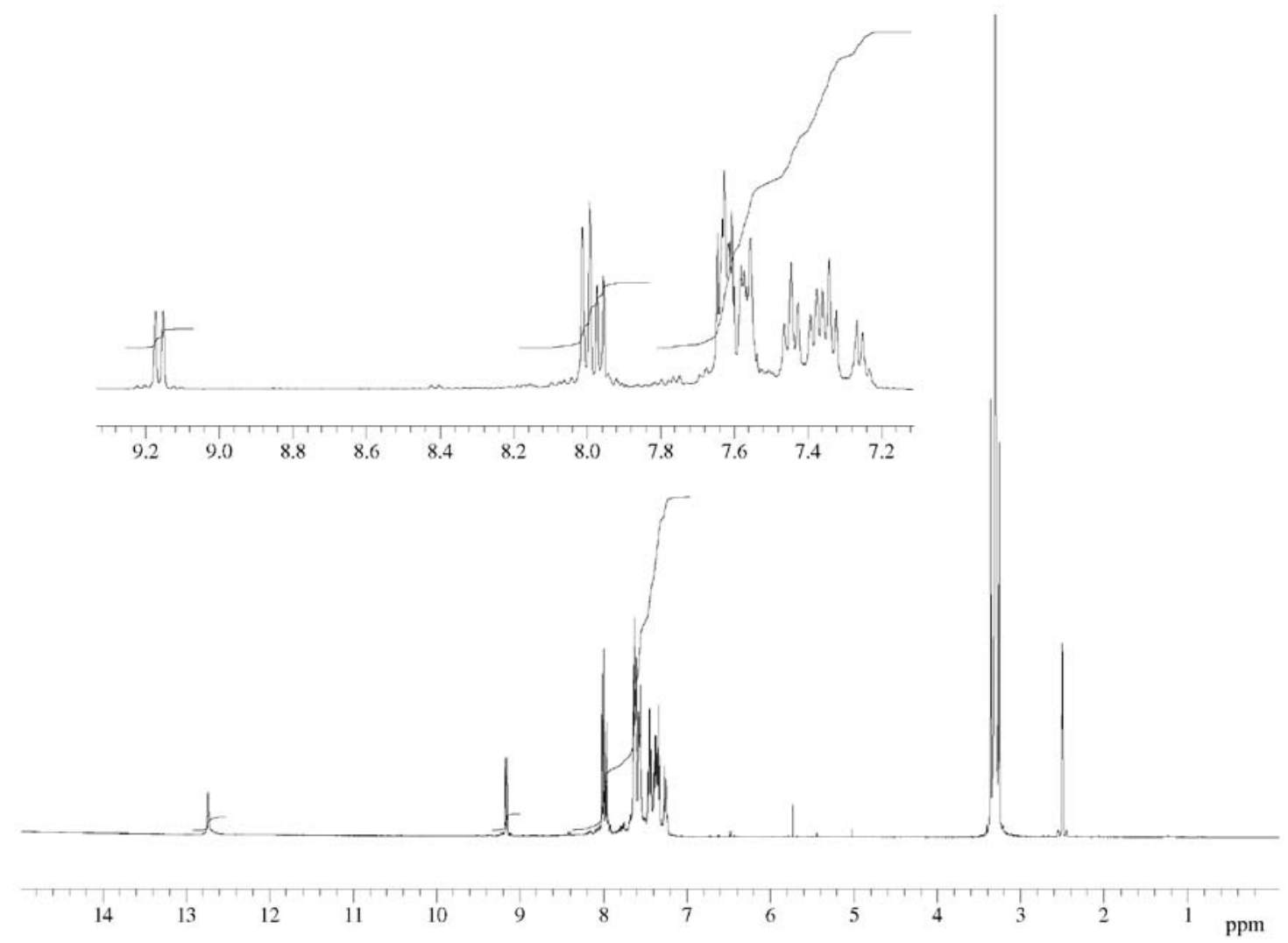

Figure S17. ${ }^{1} \mathrm{H}$ NMR spectrum (400 MHz, DMSO- $d_{6}$ ) of compound 2-(naphthalen-1-yl)-4,5-diphenyl-1H-imidazole (8e). 


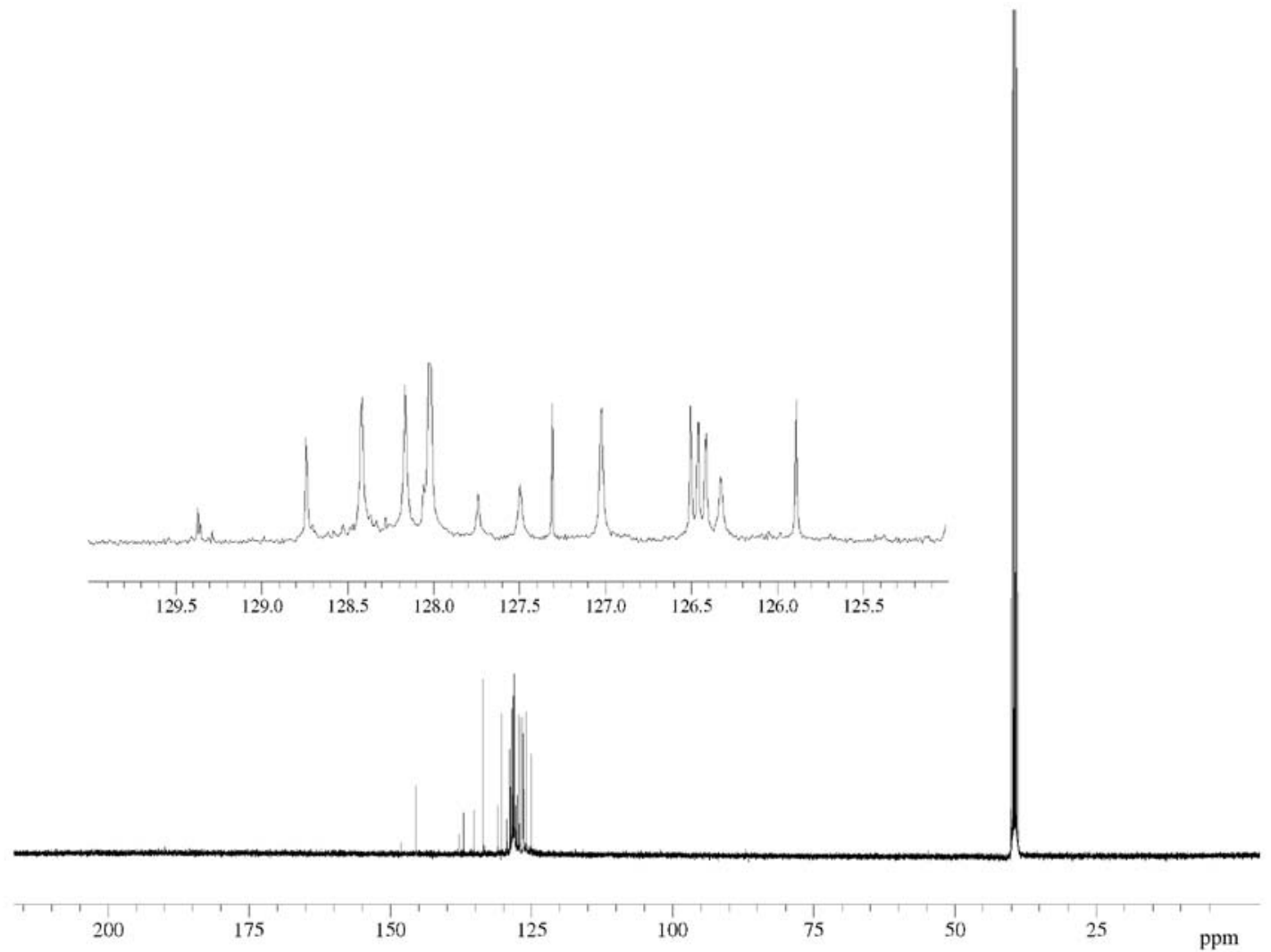

Figure S18. ${ }^{13} \mathrm{C}$ NMR spectrum $\left(100 \mathrm{MHz}, \mathrm{DMSO}-d_{6}\right)$ of compound 2-(naphthalen-1-yl)-4,5-diphenyl-1H-imidazole (8e).

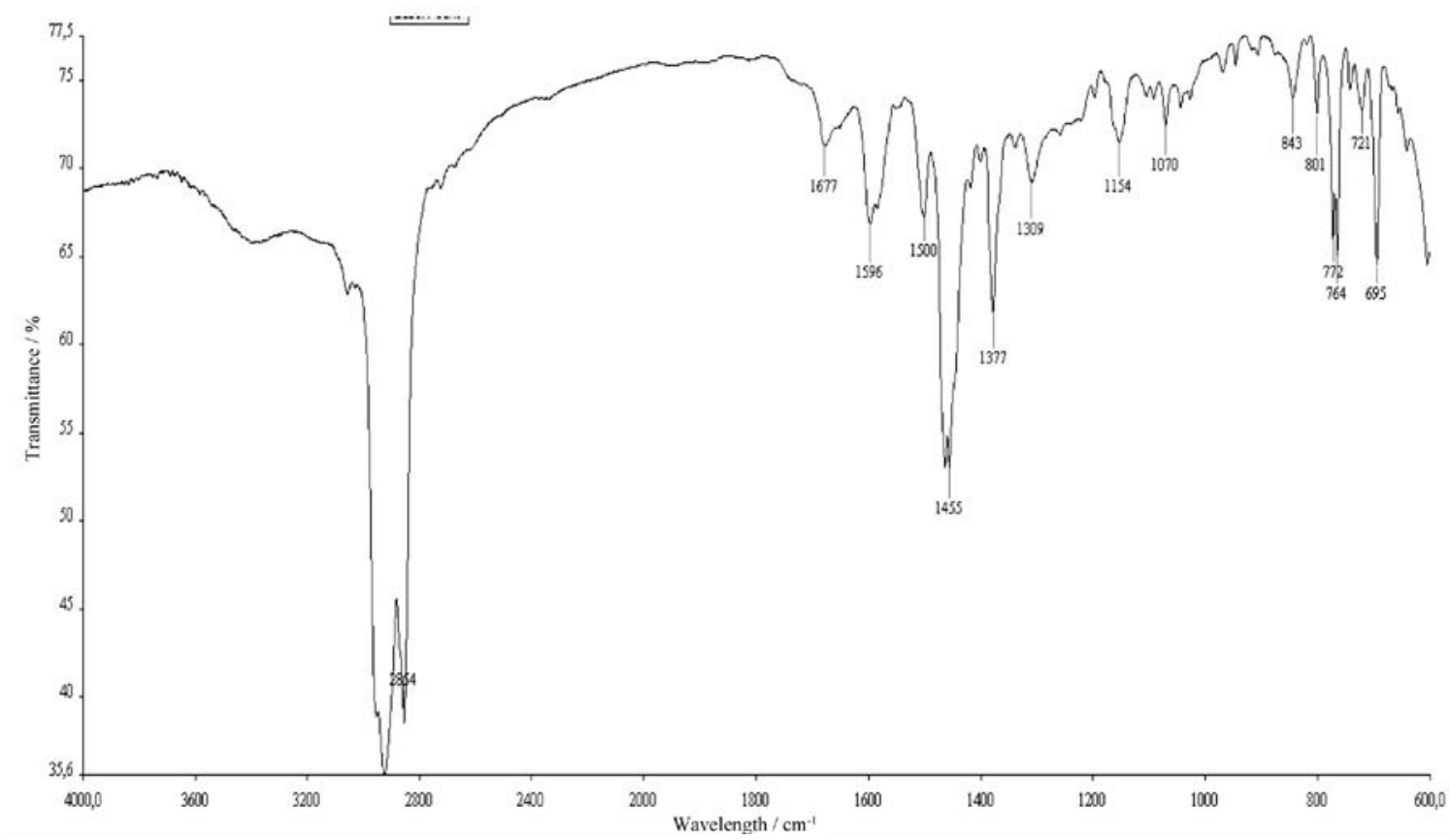

Figure S19. IR spectrum (Nujol) of compound 2-(naphthalen-1-yl)-4,5-diphenyl-1H-imidazole (8e). 


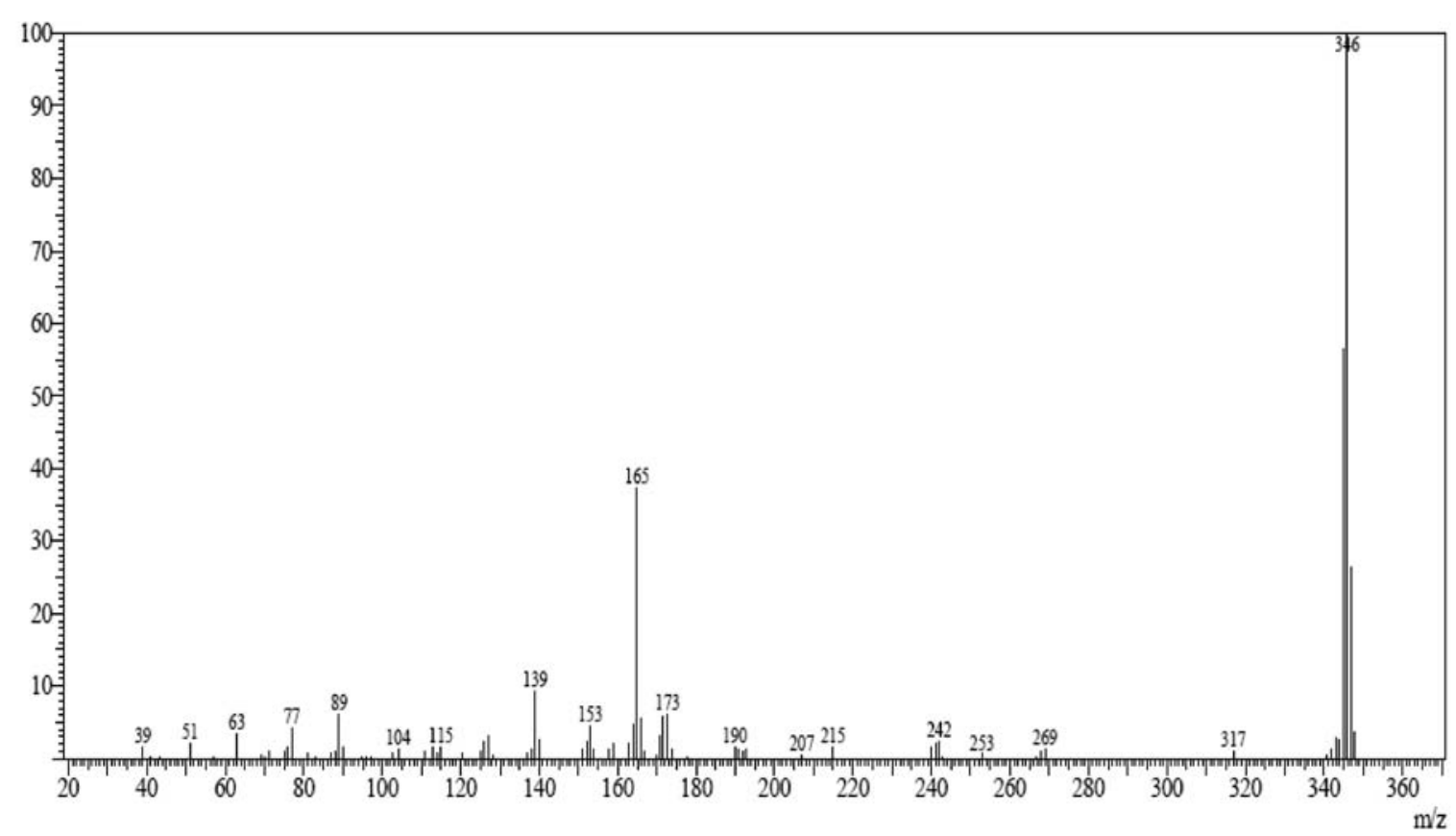

Figure S20. Mass spectrum (70 eV) of compound 2-(naphthalen-1-yl)-4,5-diphenyl-1H-imidazole (8e).
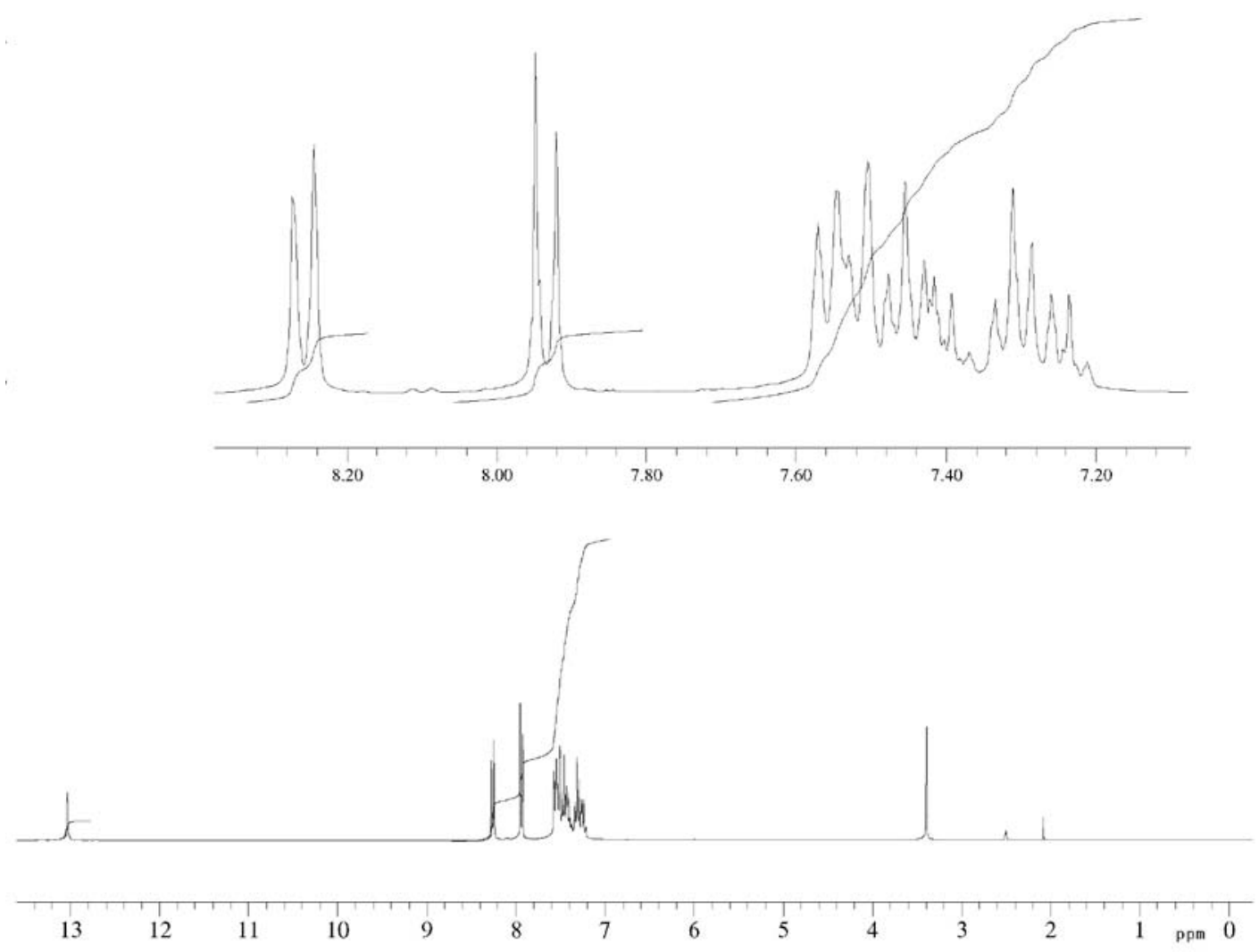

Figure S21. ' H NMR spectrum (300 MHz, DMSO- $d_{6}$ ) of compound 4-(4,5-diphenyl-1H-imidazol-2-yl)benzonitrile (8f). 

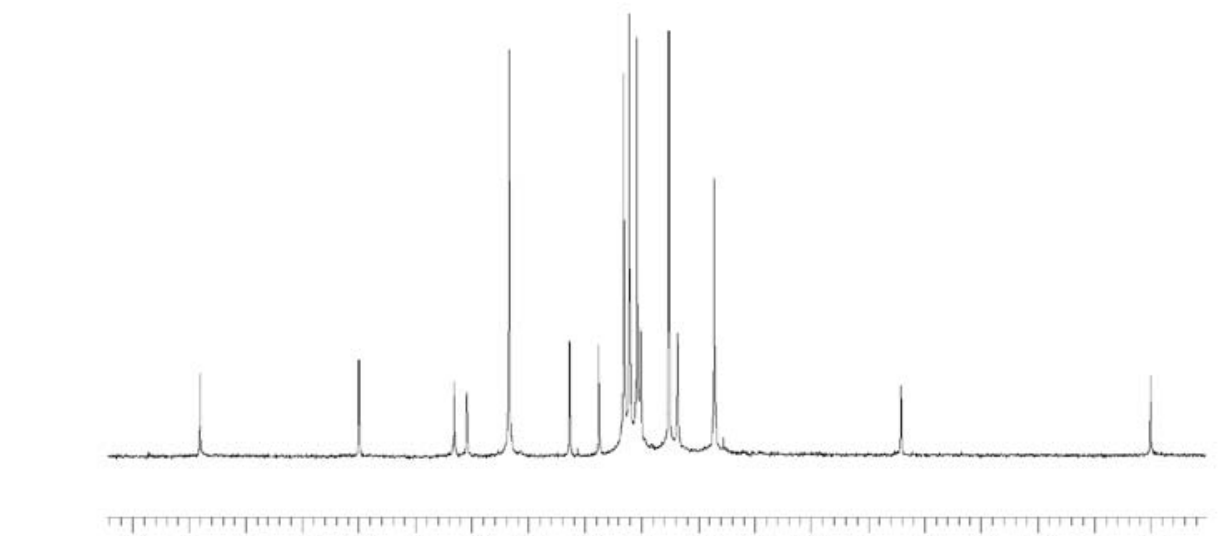

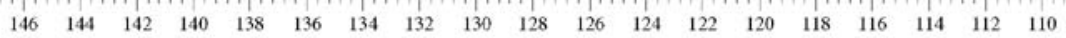

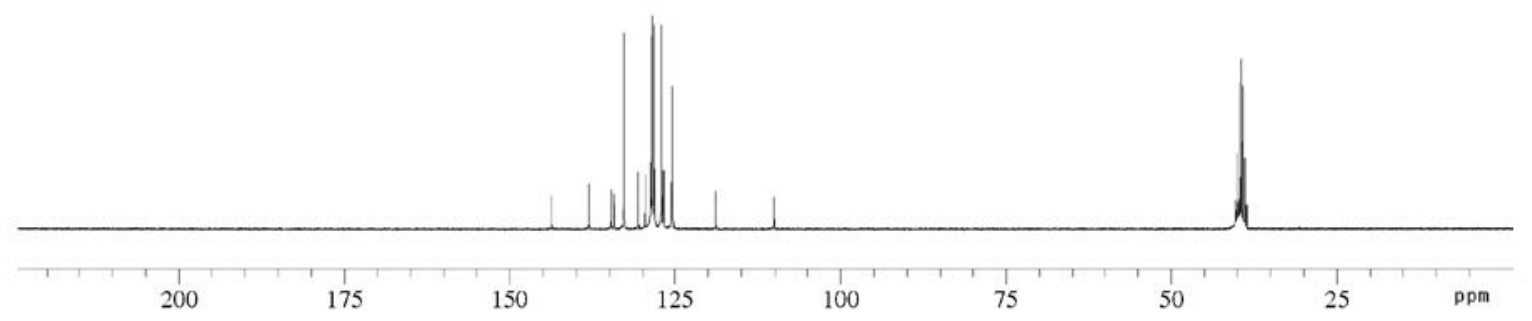

Figure S22. ${ }^{13} \mathrm{C}$ NMR spectrum (75 MHz, DMSO- $d_{6}$ ) of compound 4-(4,5-diphenyl-1H-imidazol-2-yl)benzonitrile (8f).

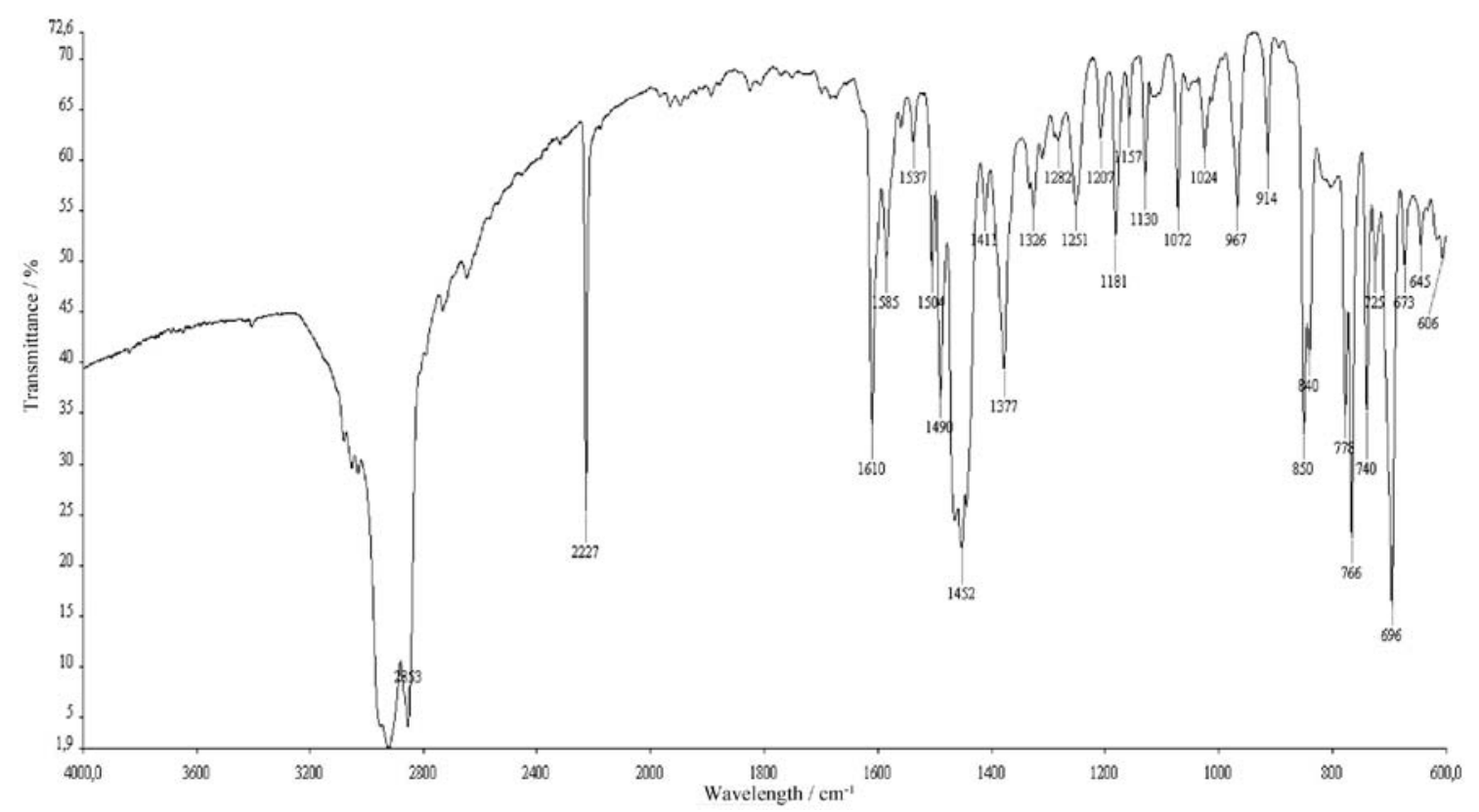

Figure S23. IR spectrum (Nujol) of compound 4-(4,5-diphenyl-1H-imidazol-2-yl)benzonitrile (8f). 


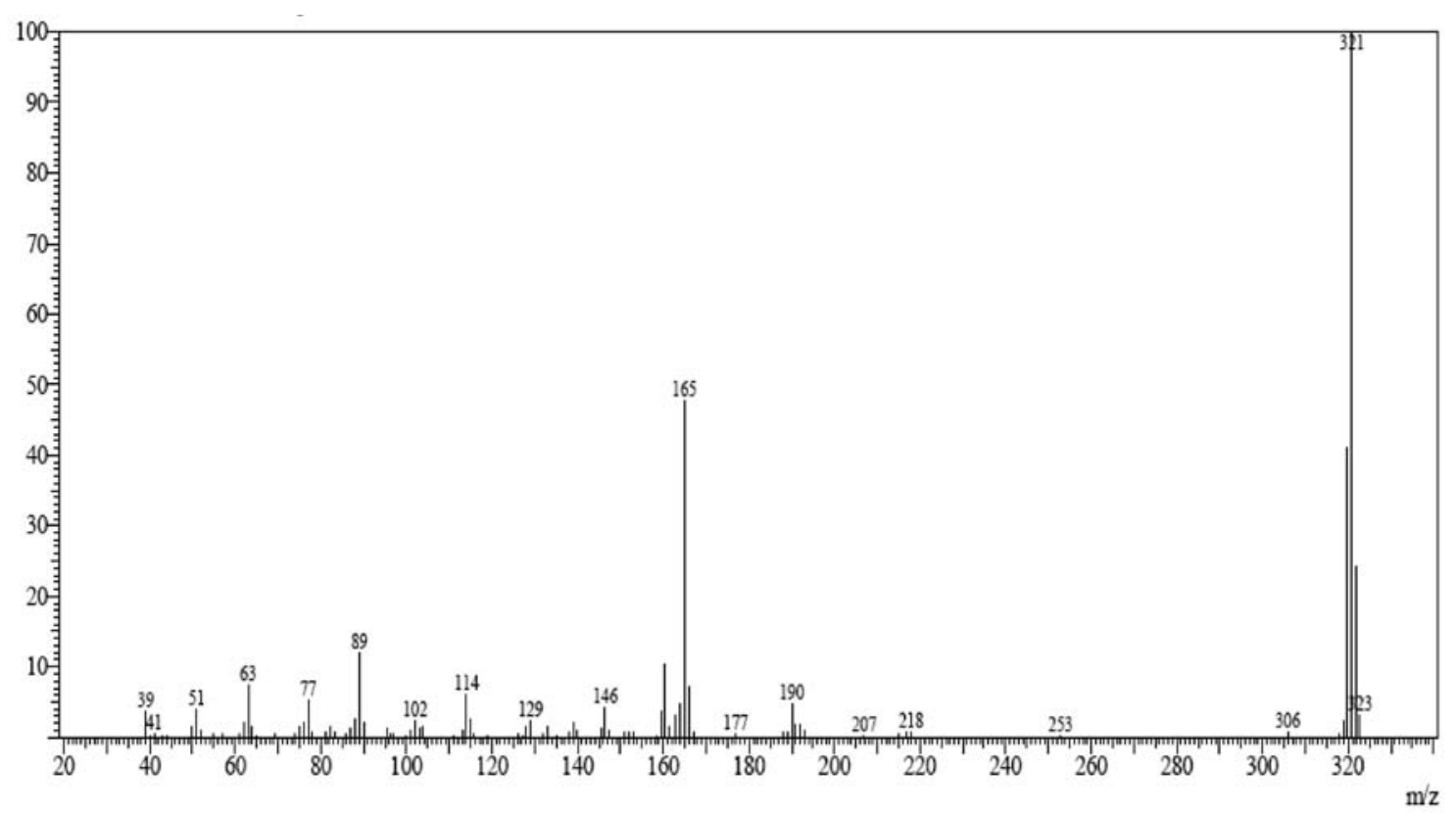

Figure S24. Mass spectrum (70 eV) of compound 4-(4,5-diphenyl-1 $H$-imidazol-2-yl)benzonitrile (8f).

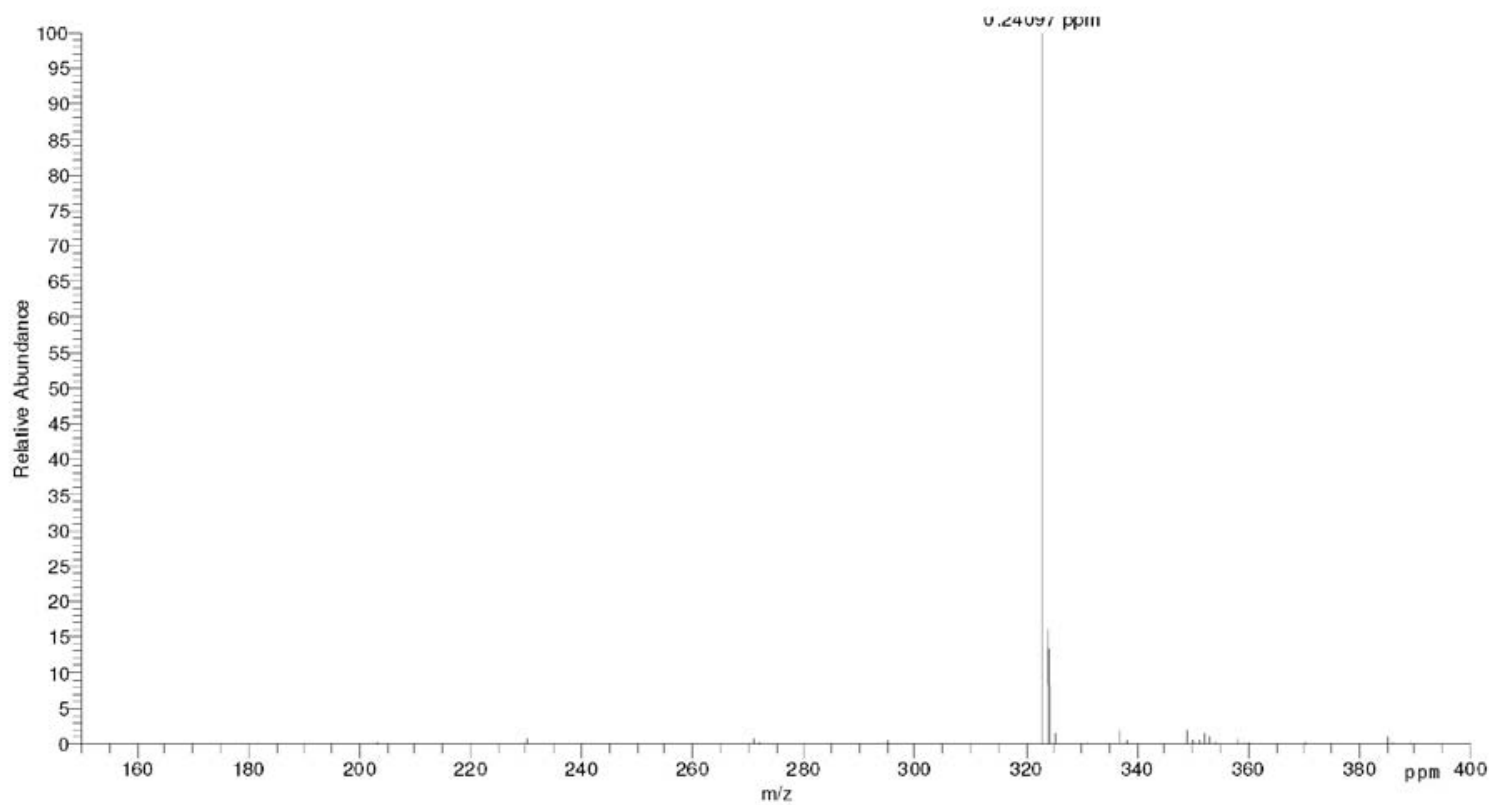

Figure S25. HRMS (ESI +) of compound 4-(4,5-diphenyl-1H-imidazol-2-yl)benzonitrile (8f). 


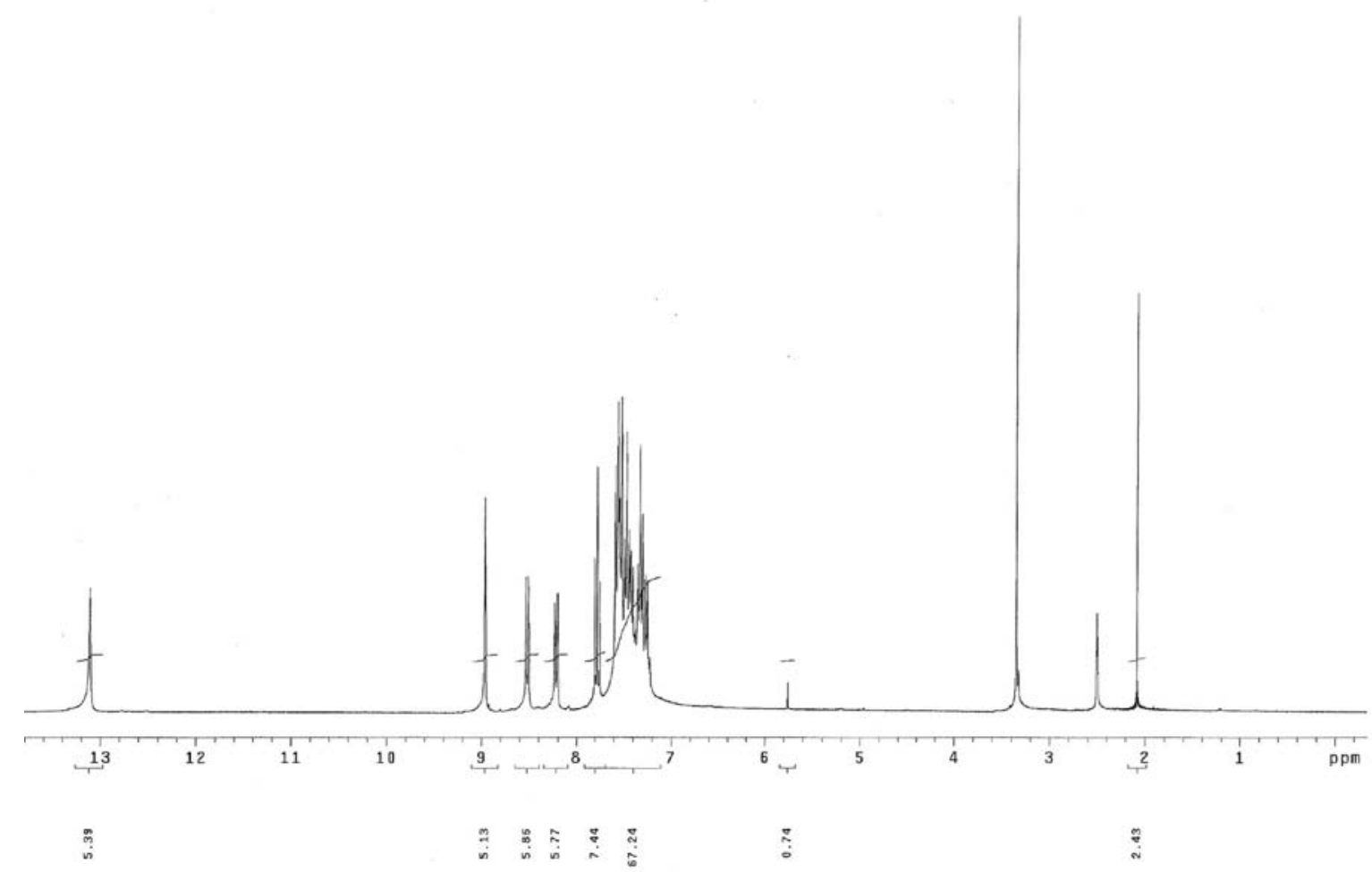

Figure S26. ${ }^{1} \mathrm{H}$ NMR spectrum (300 MHz, DMSO- $d_{6}$ ) of compound 2-(3-nitrophenyl)-4,5-diphenyl-1 $H$-imidazole (8g).

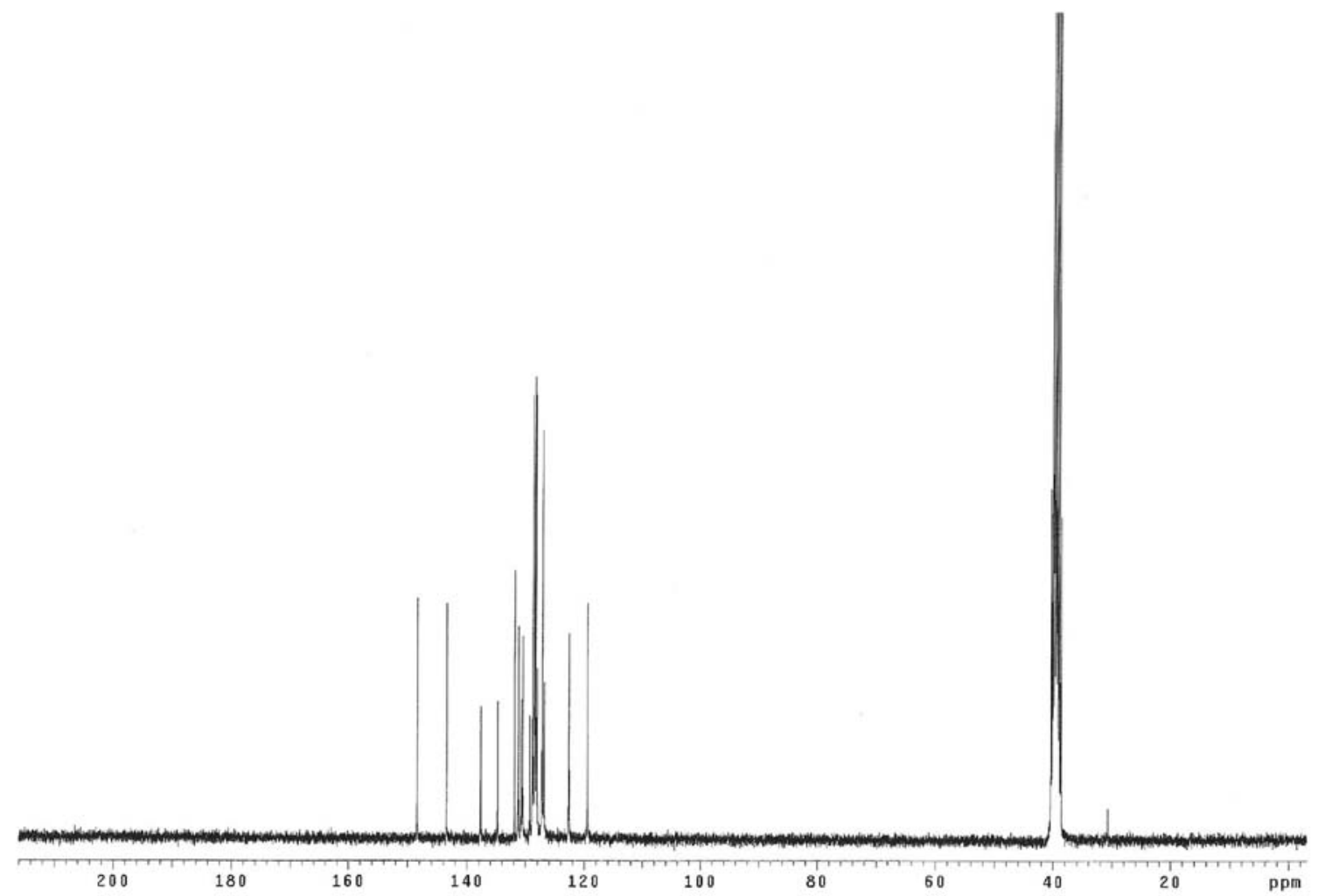

Figure S27. ${ }^{13} \mathrm{C}$ NMR spectrum (75 MHz, DMSO- $d_{6}$ ) of compound 2-(3-nitrophenyl)-4,5-diphenyl-1 $H$-imidazole (8g). 


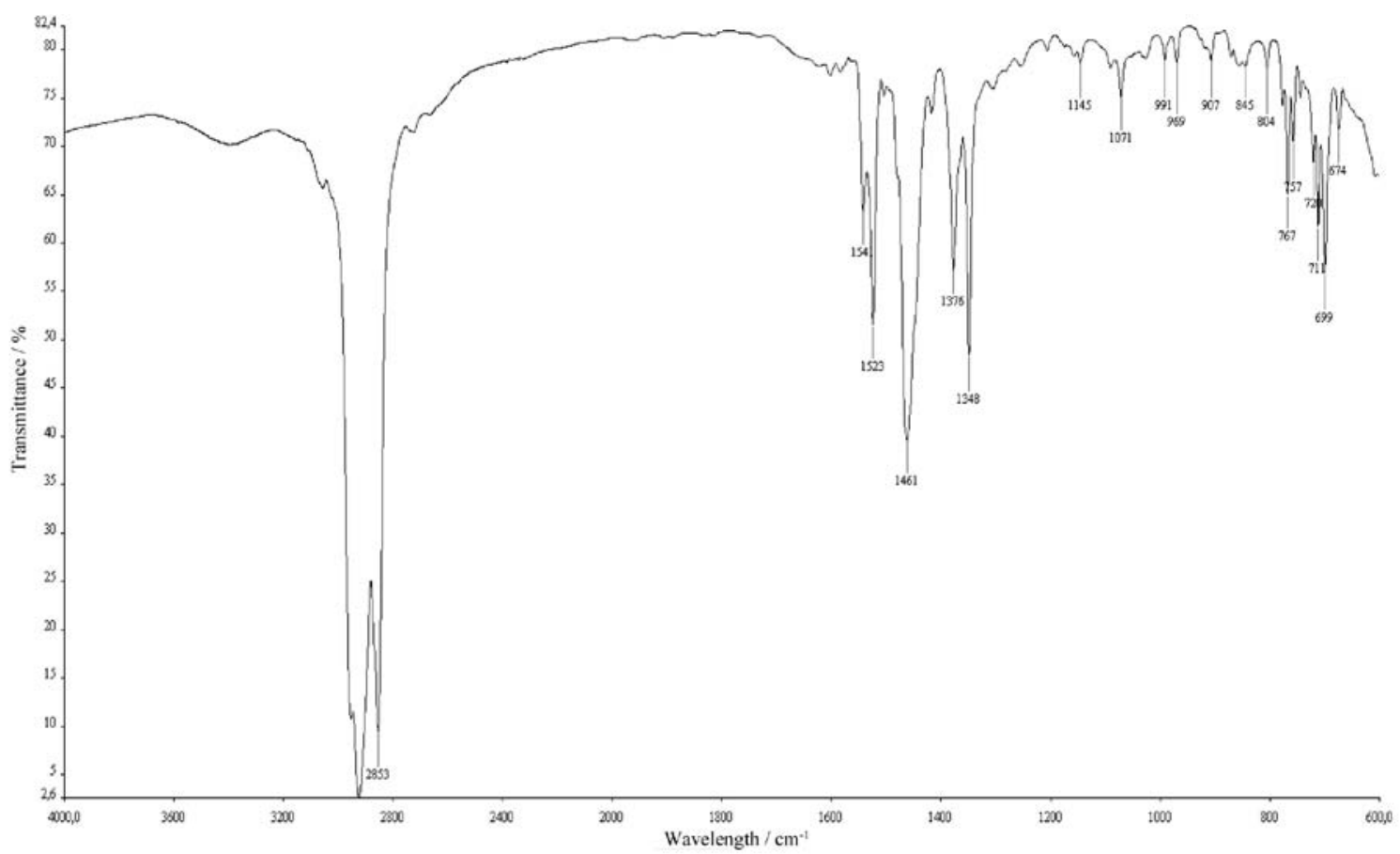

Figure S28. IR spectrum (Nujol) of compound 2-(3-nitrophenyl)-4,5-diphenyl-1H-imidazole (8g).

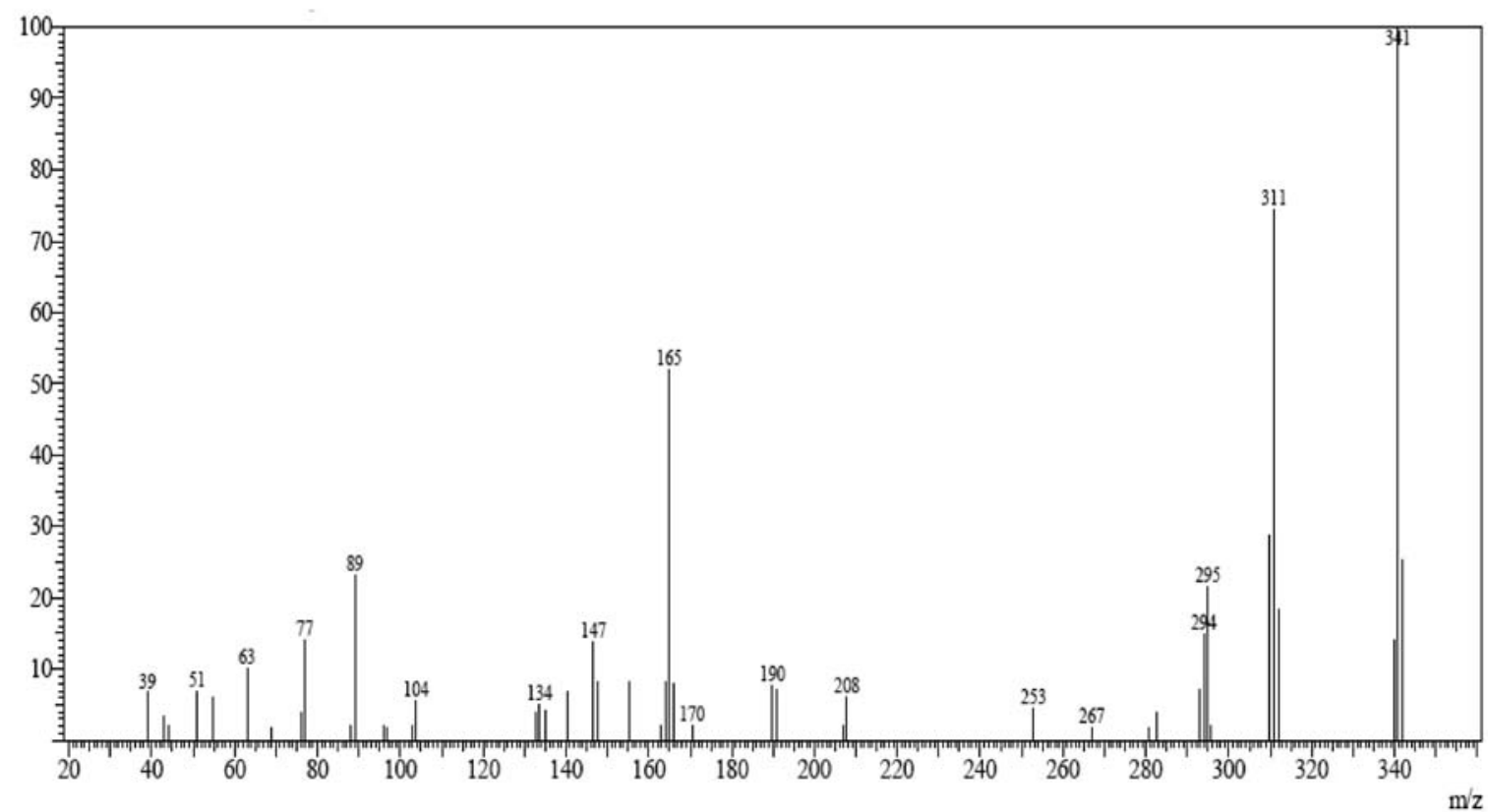

Figure S29. Mass spectrum (70 eV) of compound 2-(3-nitrophenyl)-4,5-diphenyl-1H-imidazole (8g). 


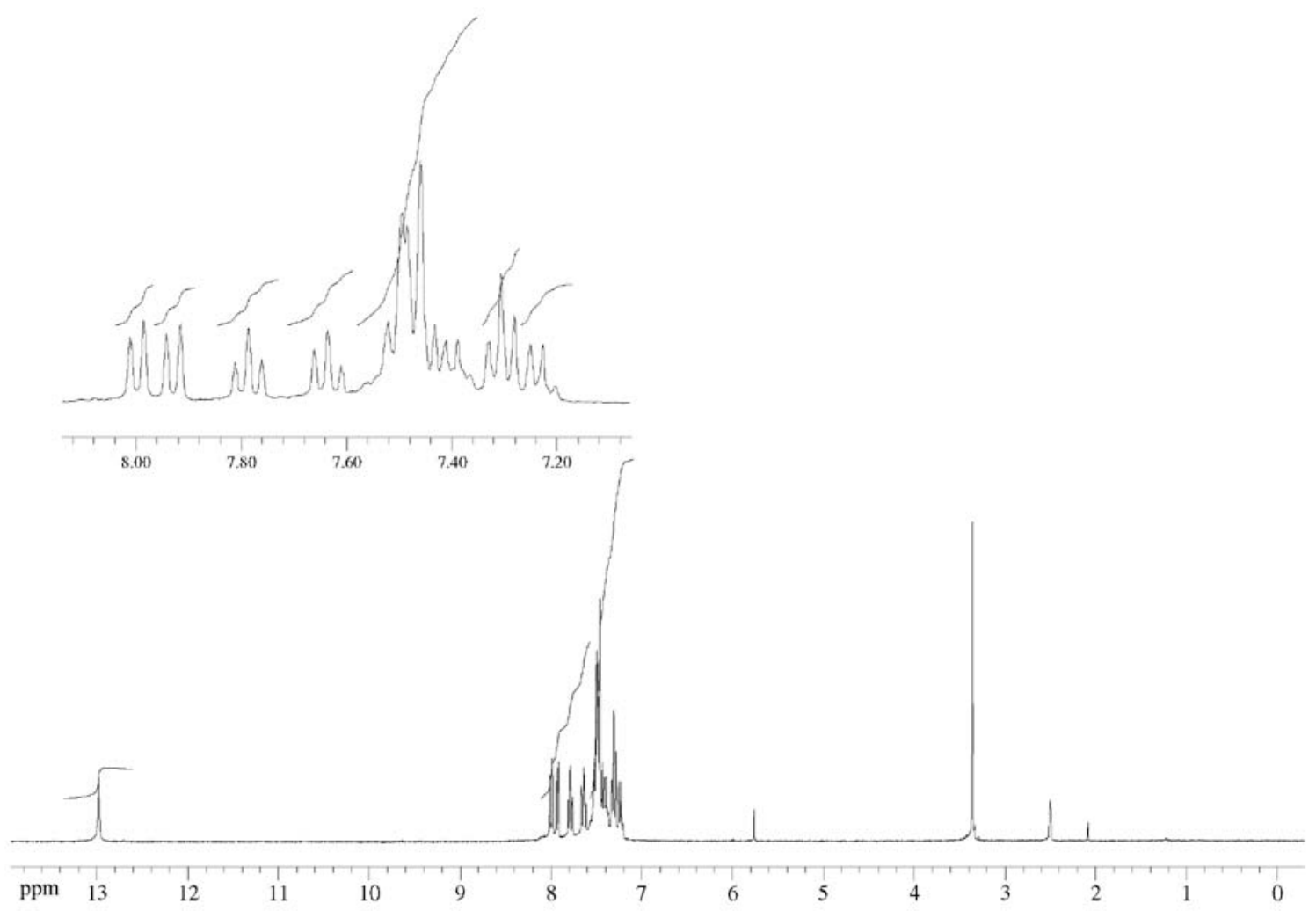

Figure S30. ${ }^{1} \mathrm{H}$ NMR spectrum (300 MHz, DMSO- $d_{6}$ ) of compound 2-(2-nitrophenyl)-4,5-diphenyl-1 $H$-imidazole $(\mathbf{8 h})$.

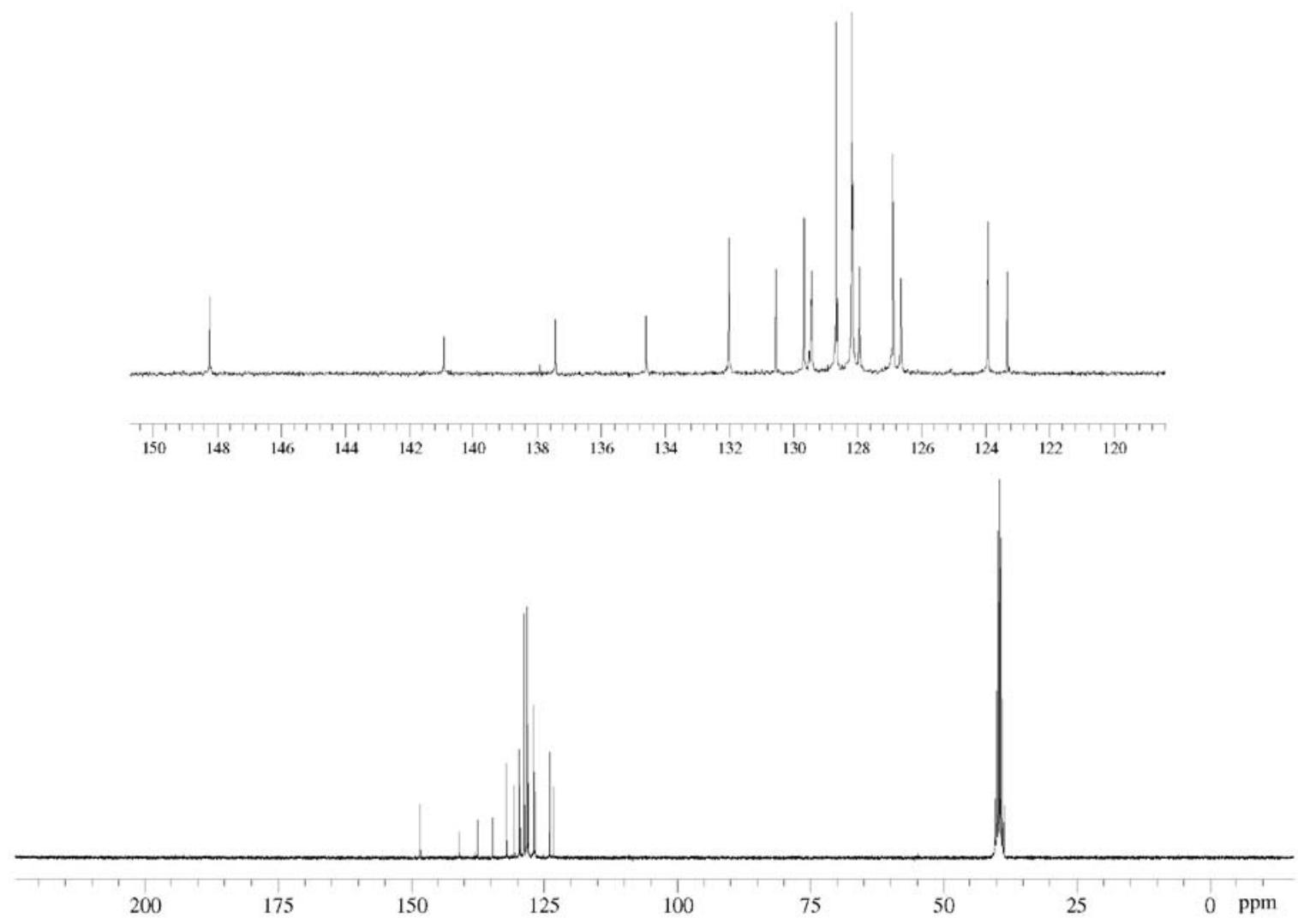

Figure S31. ${ }^{13} \mathrm{C}$ NMR spectrum (75 MHz, DMSO- $d_{6}$ ) of compound 2-(2-nitrophenyl)-4,5-diphenyl-1H-imidazole (8h). 


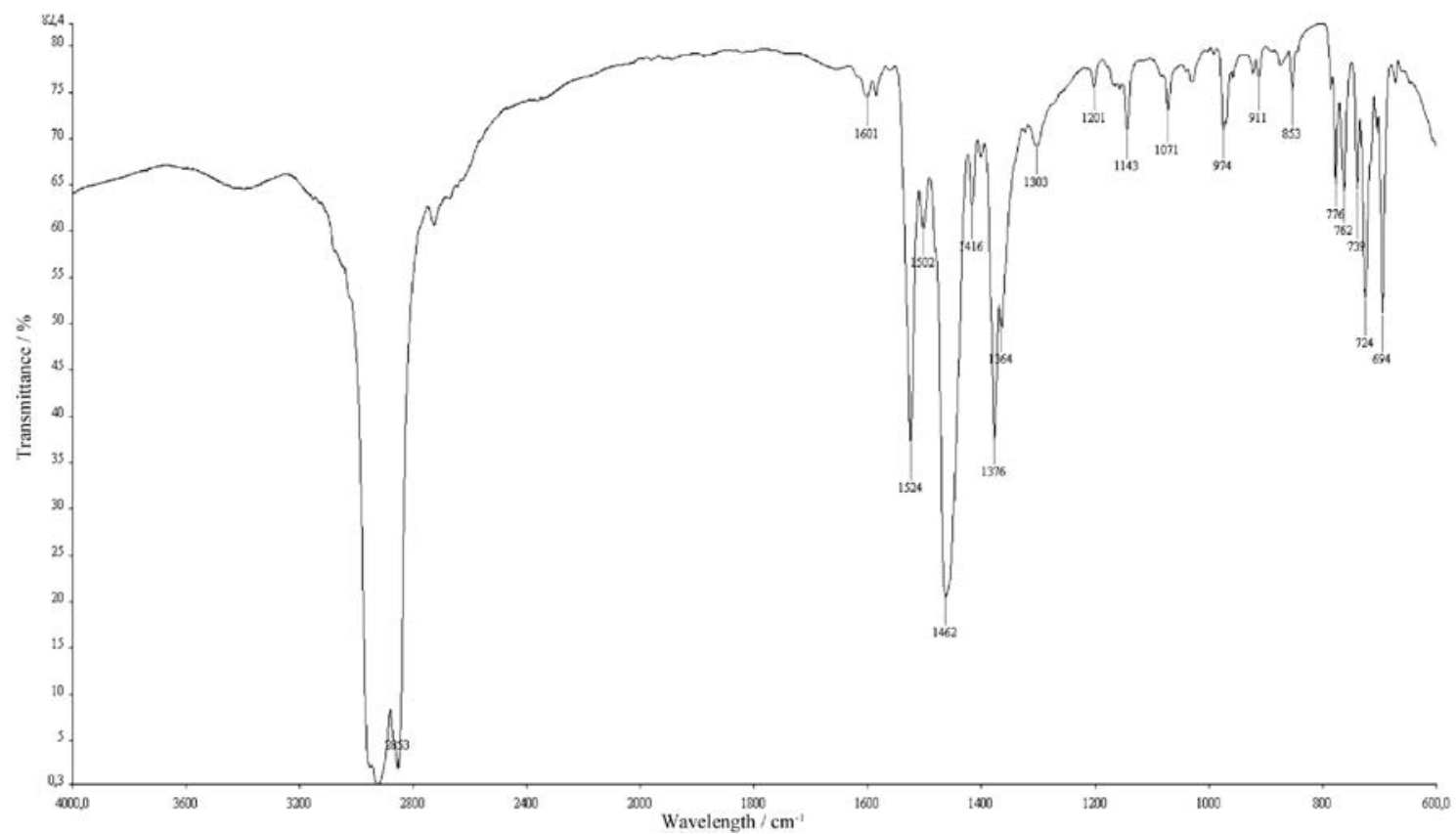

Figure S32. IR spectrum (Nujol) of compound 2-(2-nitrophenyl)-4,5-diphenyl-1H-imidazole (8h).

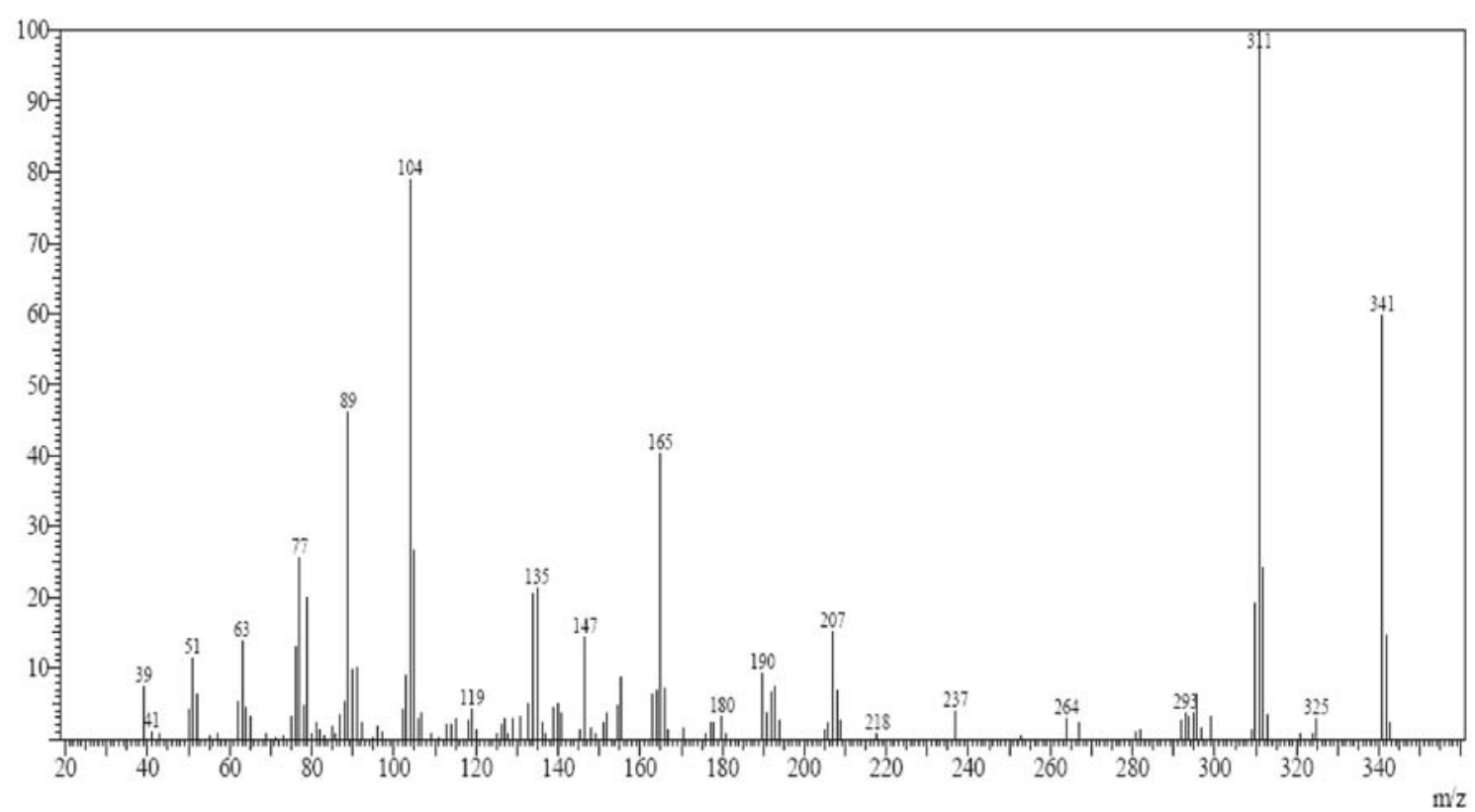

Figure S33. Mass spectrum (70 eV) of compound 2-(2-nitrophenyl)-4,5-diphenyl-1 $H$-imidazole (8h). 


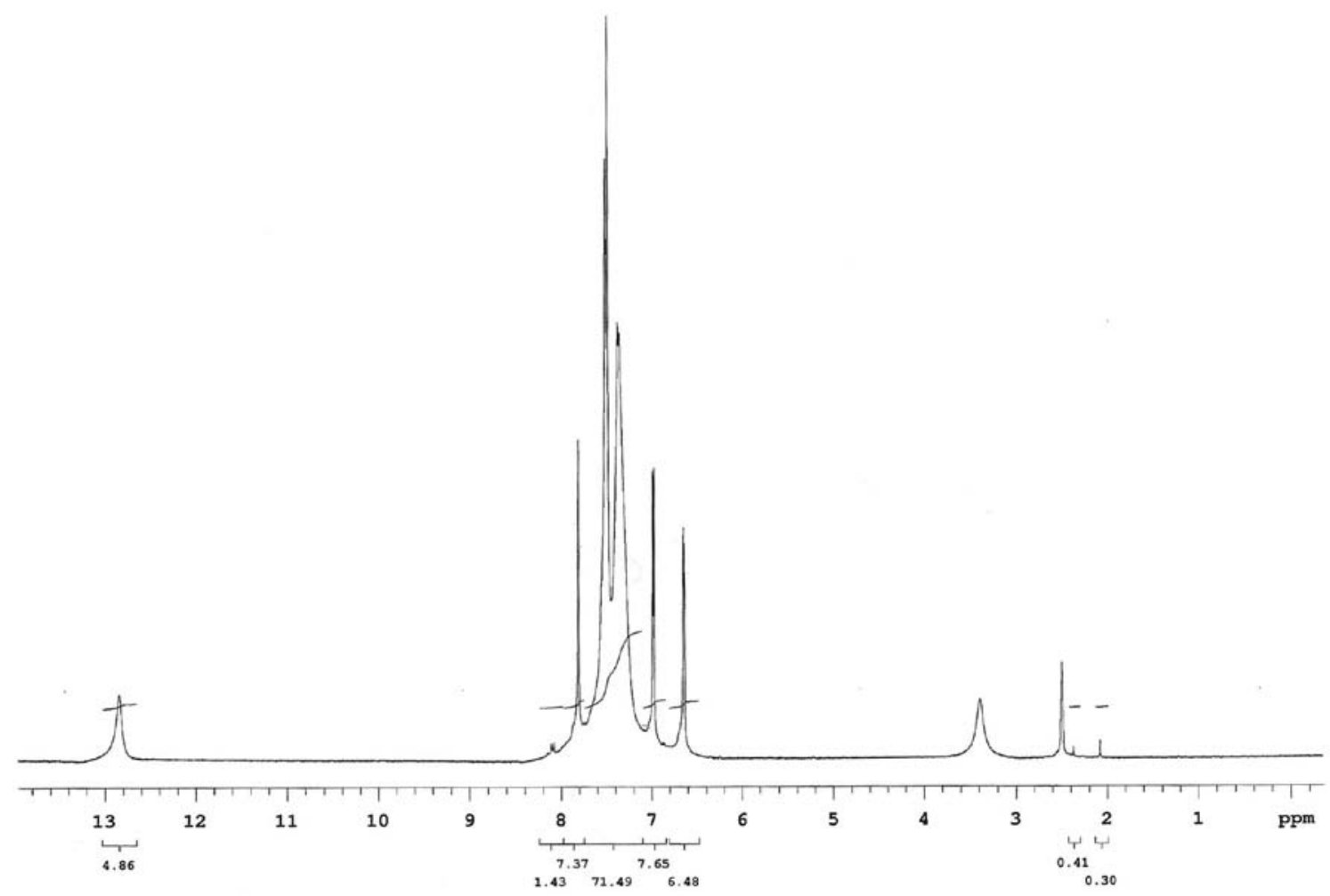

Figure S34. ${ }^{1} \mathrm{H}$ NMR spectrum (300 MHz, DMSO- $d_{6}$ ) of compound 2-(furan-2-yl)-4,5-diphenyl- $1 H$-imidazole (8i).

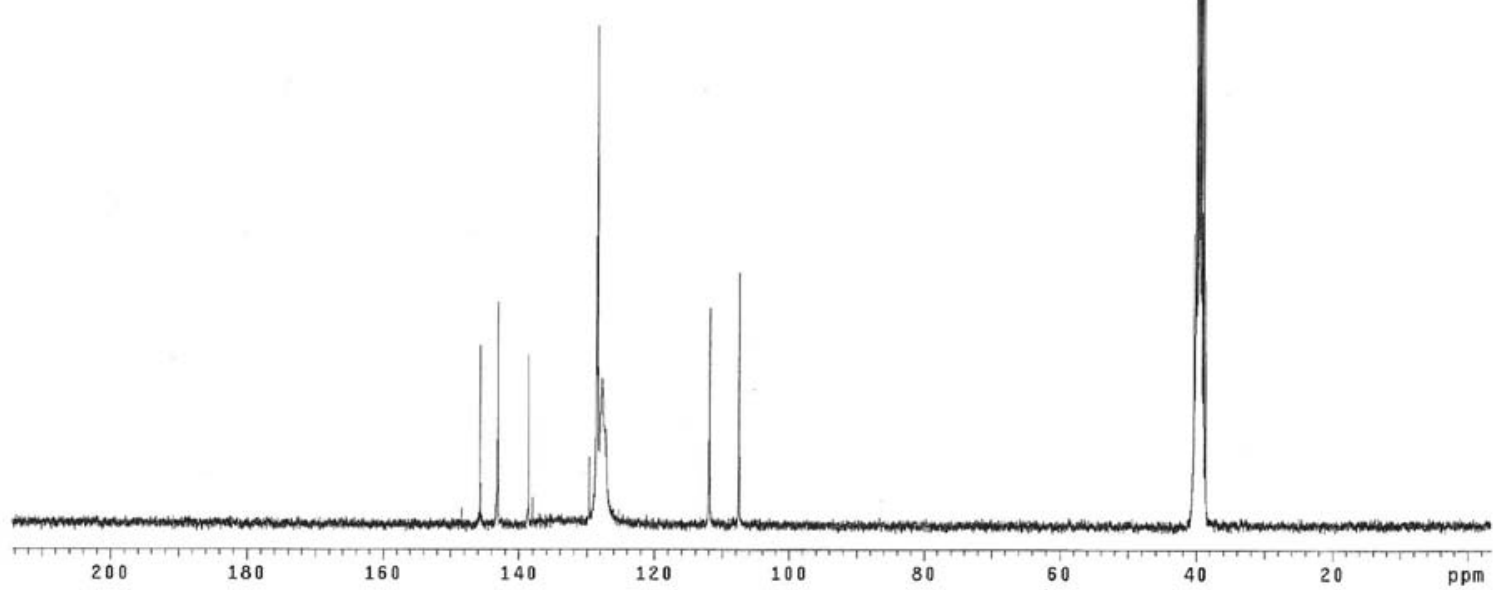

Figure S35. ${ }^{13} \mathrm{C}$ NMR spectrum (75 MHz, DMSO- $d_{6}$ ) of compound 2-(furan-2-yl)-4,5-diphenyl- $1 H$-imidazole (8i). 


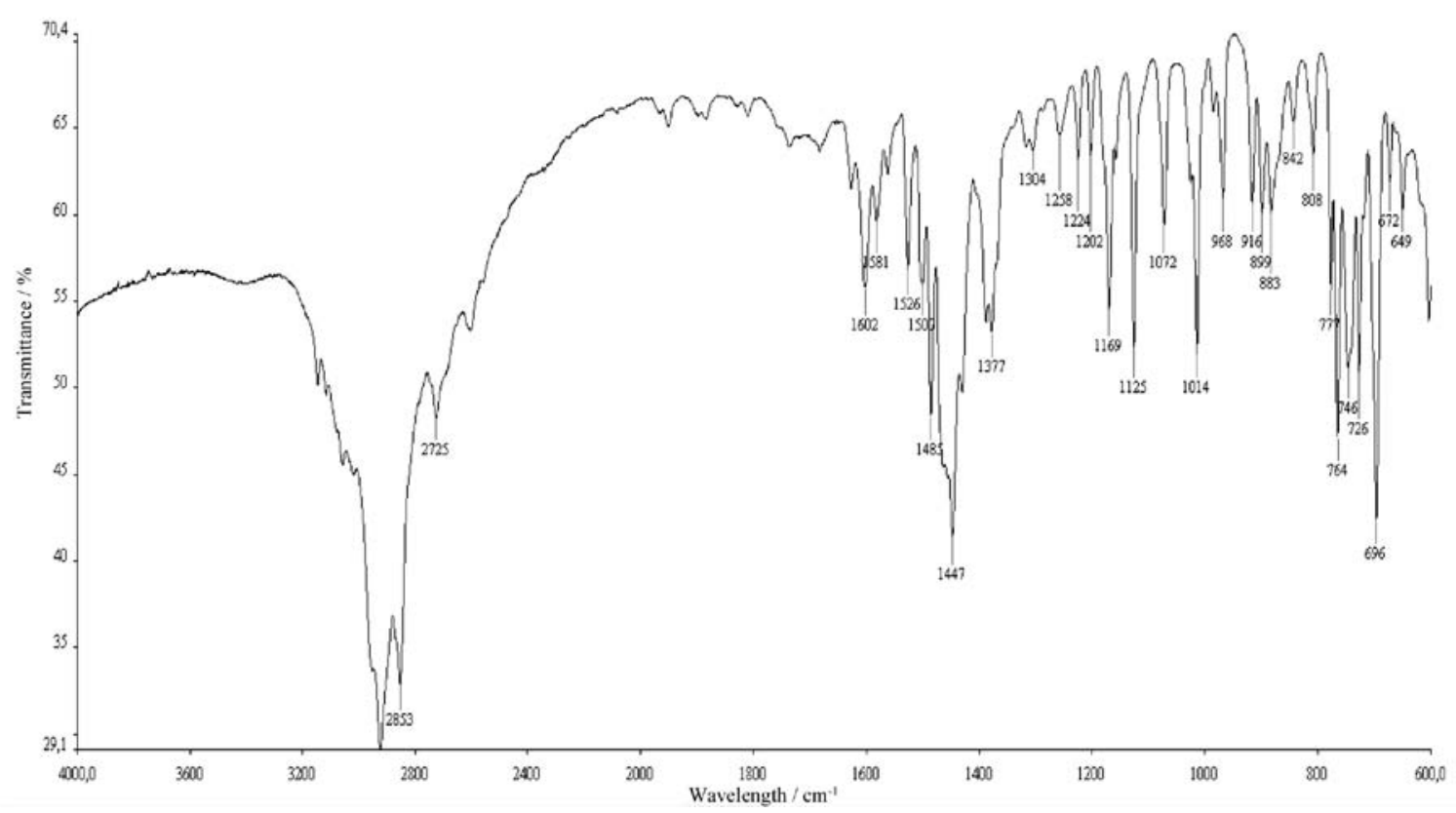

Figure S36. IR spectrum (Nujol) of compound 2-(furan-2-yl)-4,5-diphenyl-1 $H$-imidazole (8i).

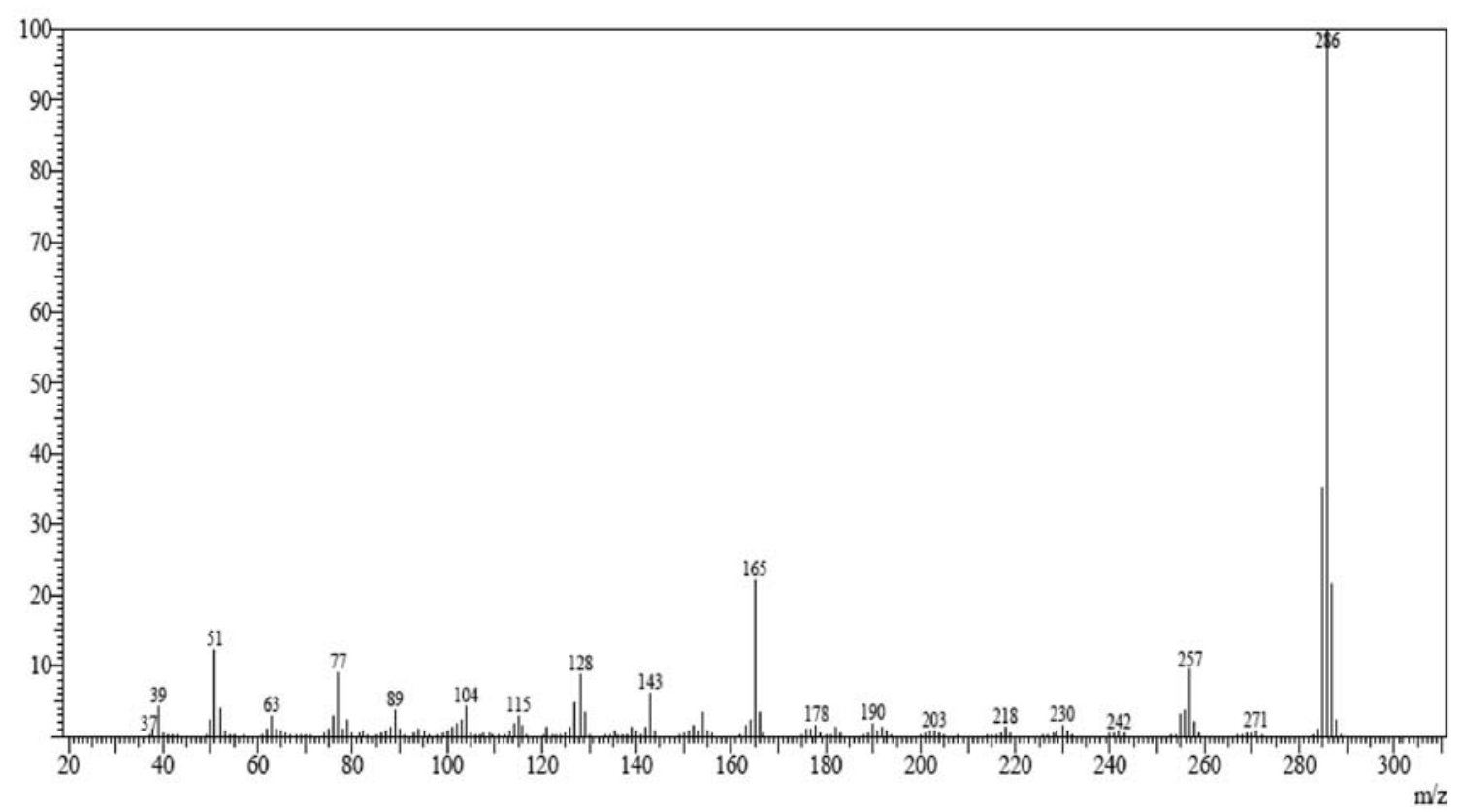

Figure S37. Mass spectrum (70 eV) of compound 2-(furan-2-yl)-4,5-diphenyl-1H-imidazole (8i). 

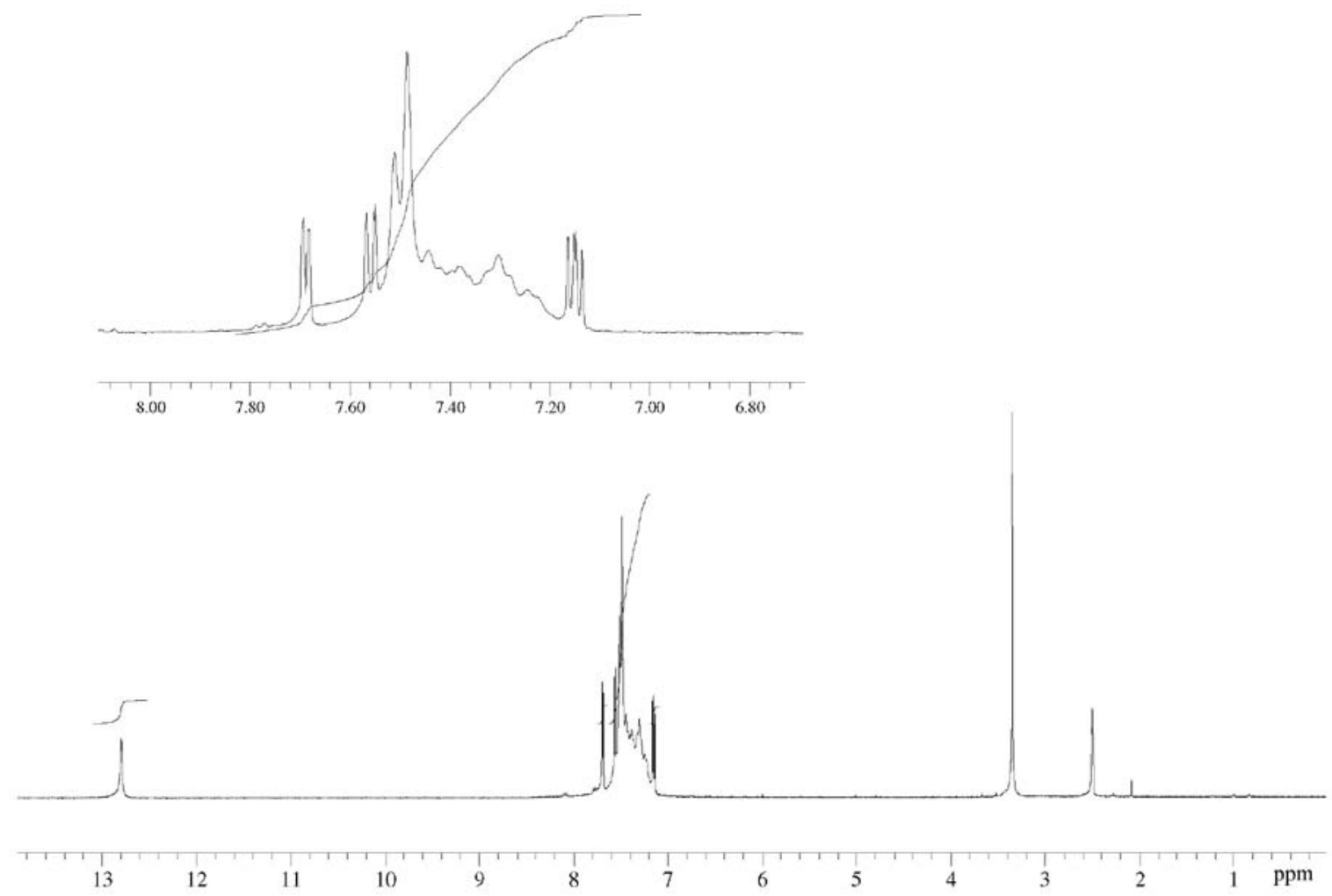

Figure S38. ${ }^{1} \mathrm{H}$ NMR spectrum (300 MHz, DMSO- $d_{6}$ ) of compound 4,5-diphenyl-2-(thiophen-2-yl)-1H-imidazole (8j).

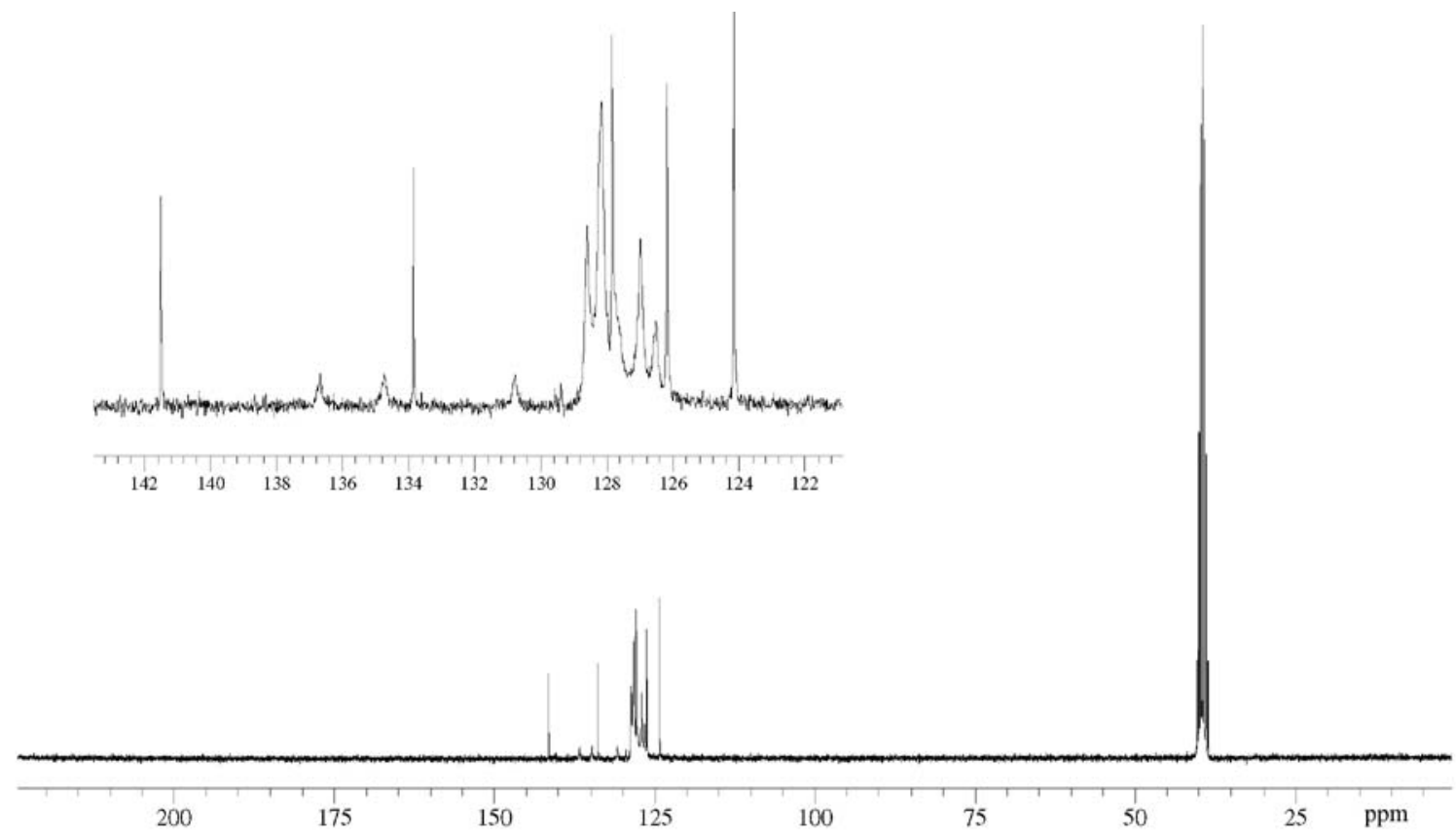

Figure S39. ${ }^{13} \mathrm{C}$ NMR spectrum (75 MHz, DMSO- $d_{6}$ ) of compound 4,5-diphenyl-2-(thiophen-2-yl)-1 $H$-imidazole $(\mathbf{8 j})$. 


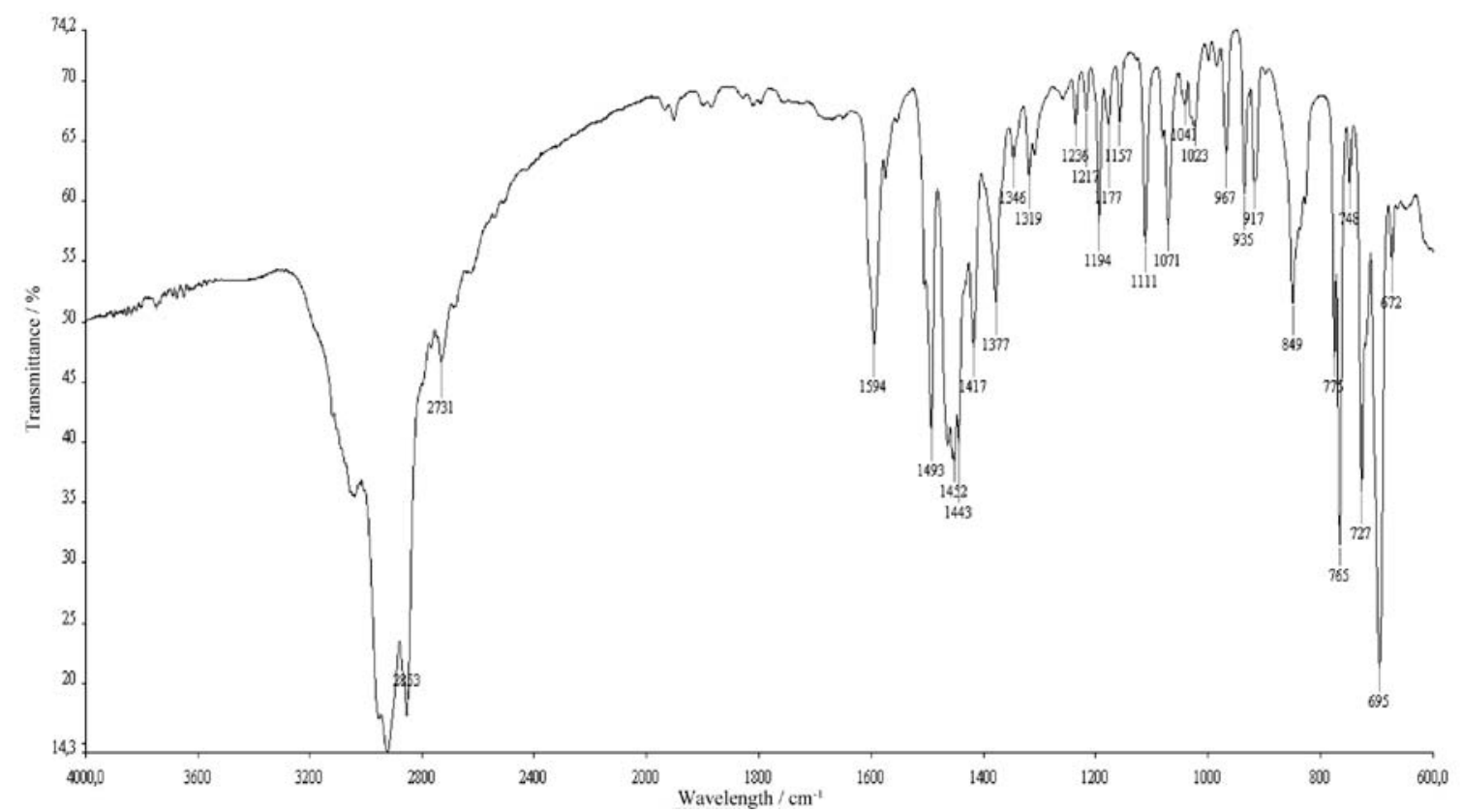

Figure S40. IR spectrum (Nujol) of compound 4,5-diphenyl-2-(thiophen-2-yl)-1H-imidazole (8j).

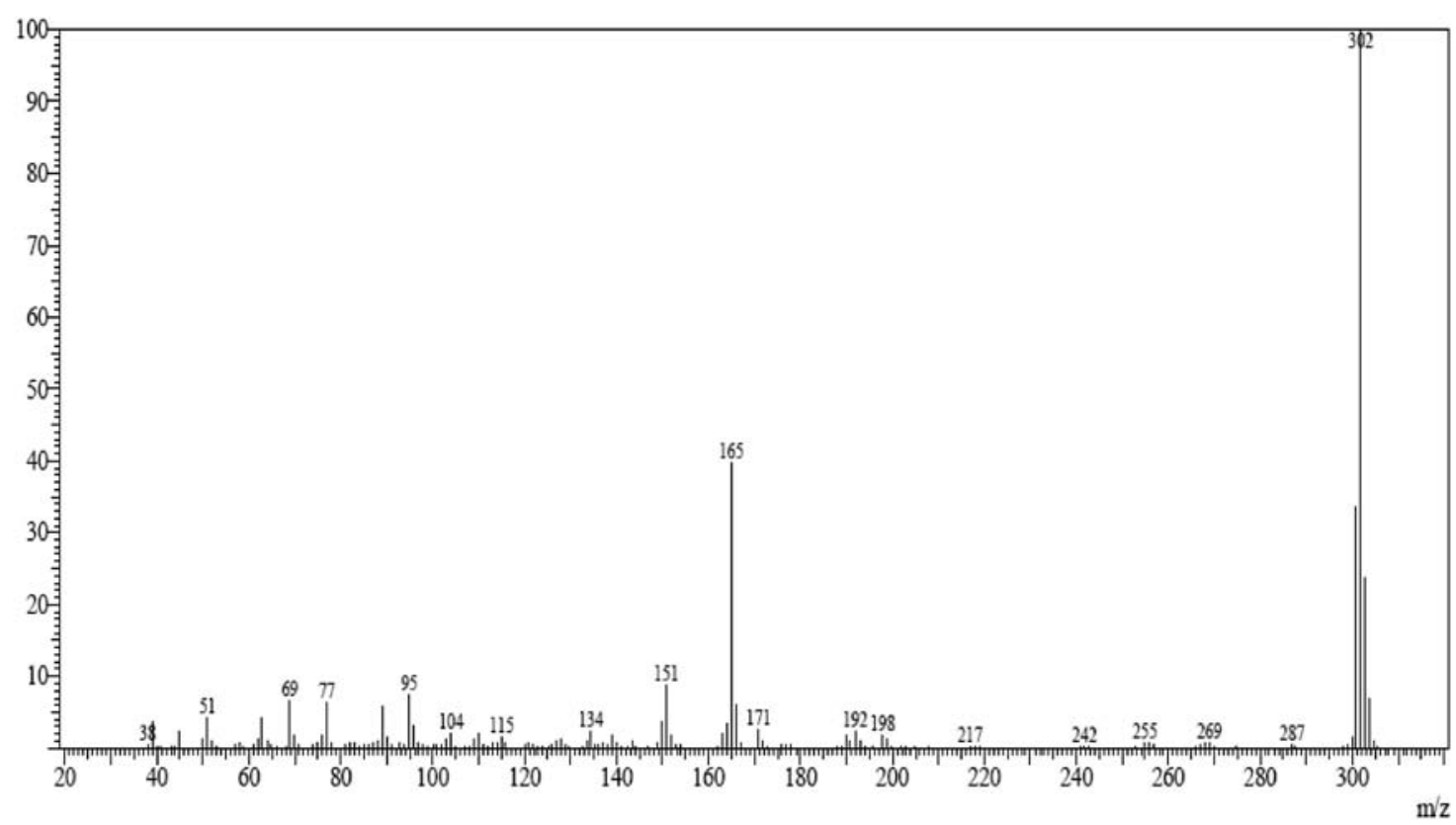

Figure S41. Mass spectrum (70 eV) of compound 4,5-diphenyl-2-(thiophen-2-yl)-1H-imidazole (8j). 


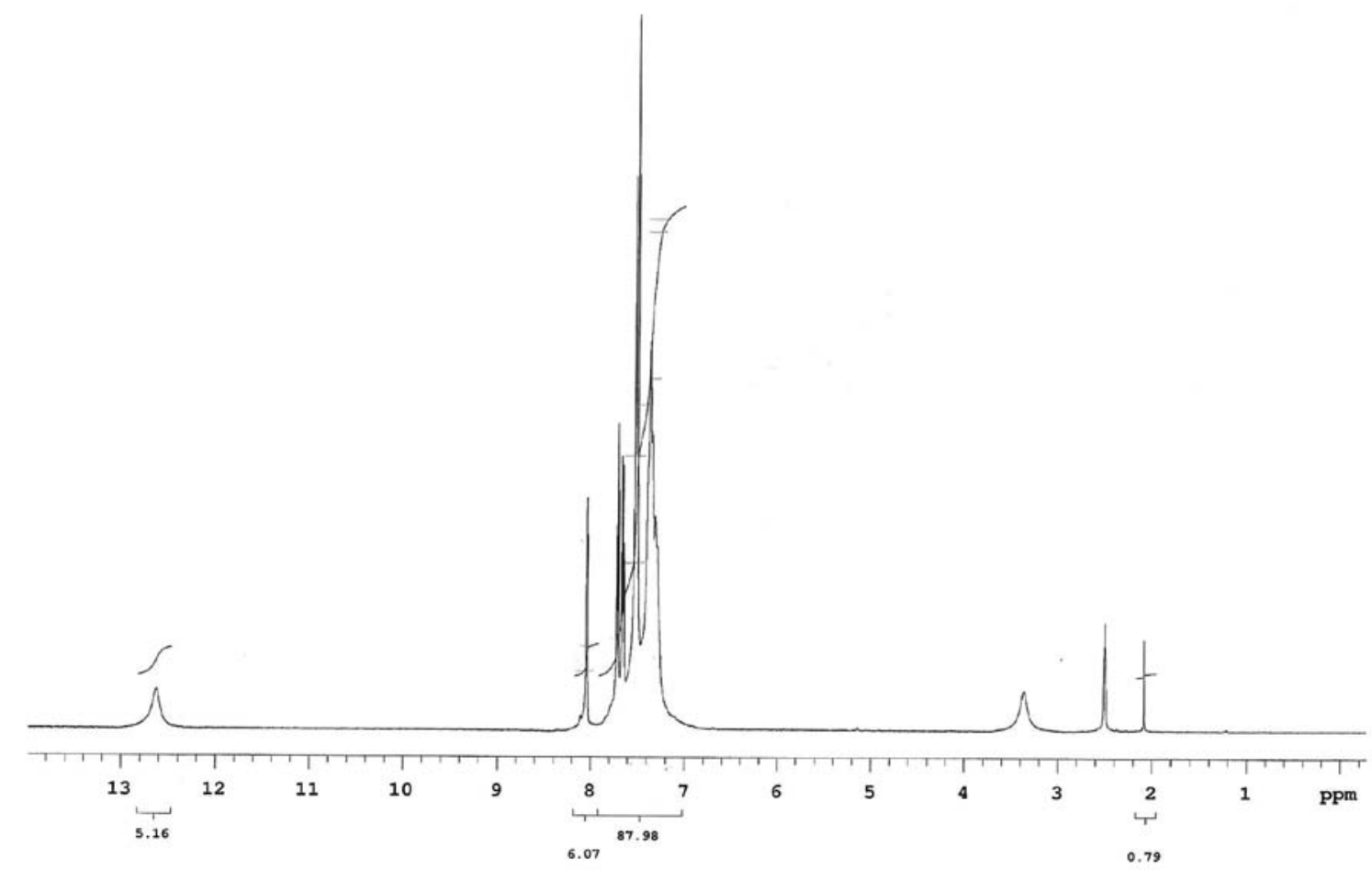

Figure S42. ${ }^{1} \mathrm{H}$ NMR spectrum (300 MHz, DMSO- $d_{6}$ ) of compound 4,5-diphenyl-2-(thiophen-3-yl)-1H-imidazole (8k).

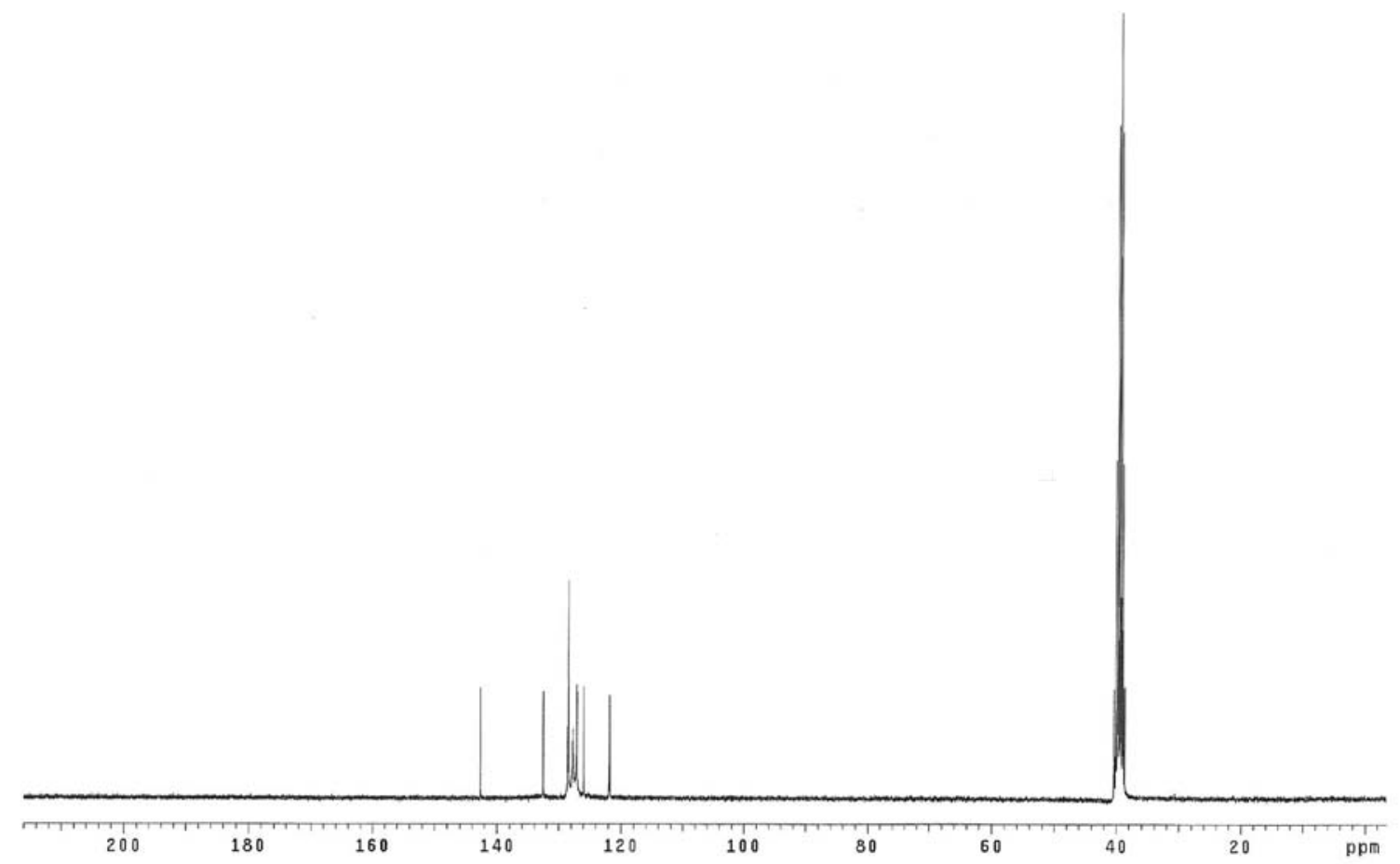

Figure S43. ${ }^{13} \mathrm{C}$ NMR spectrum (75 MHz, DMSO- $d_{6}$ ) of compound 4,5-diphenyl-2-(thiophen-3-yl)-1 $H$-imidazole (8k). 


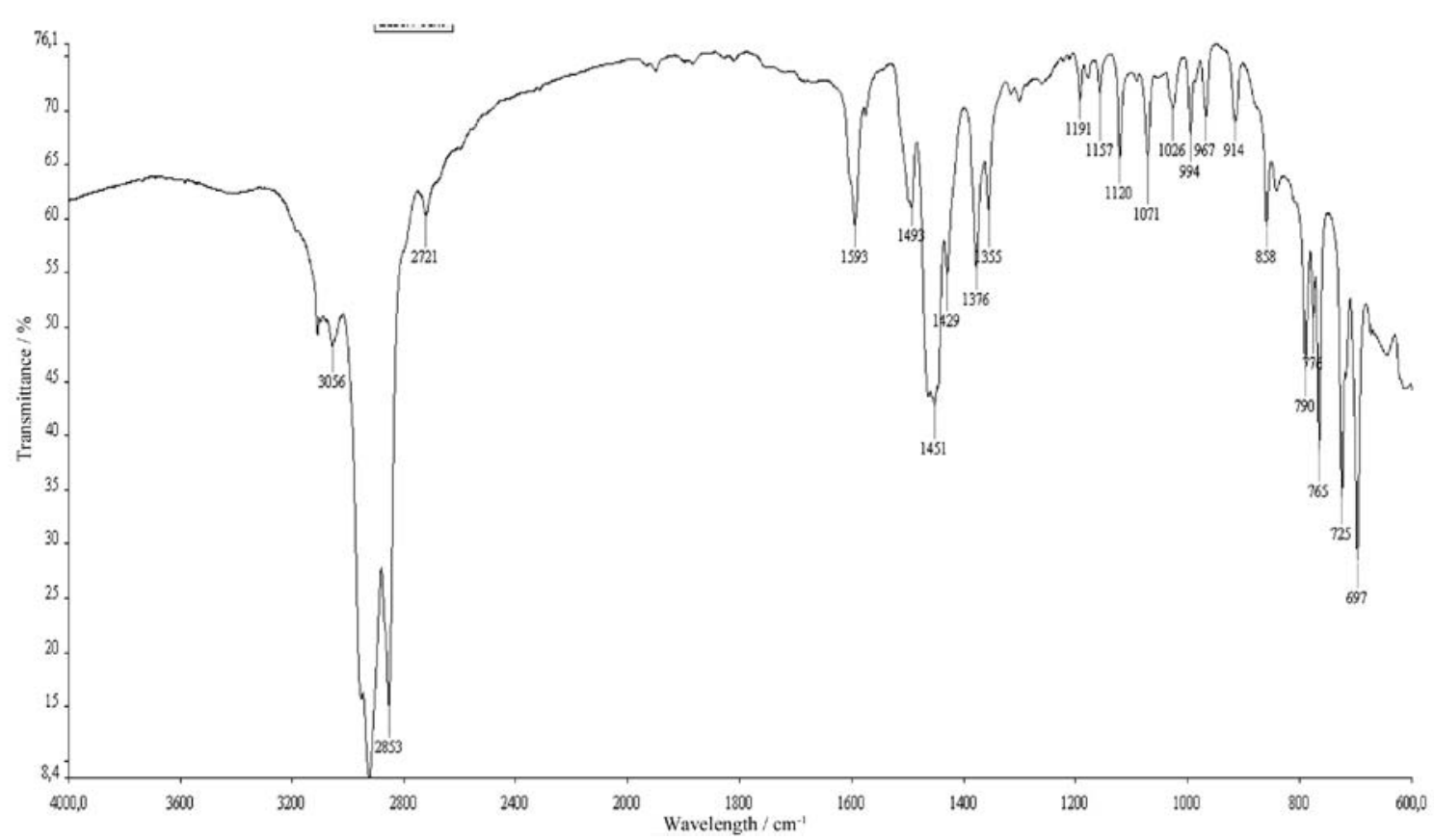

Figure S44. IR spectrum (Nujol) of compound 4,5-diphenyl-2-(thiophen-3-yl)-1H-imidazole (8k).

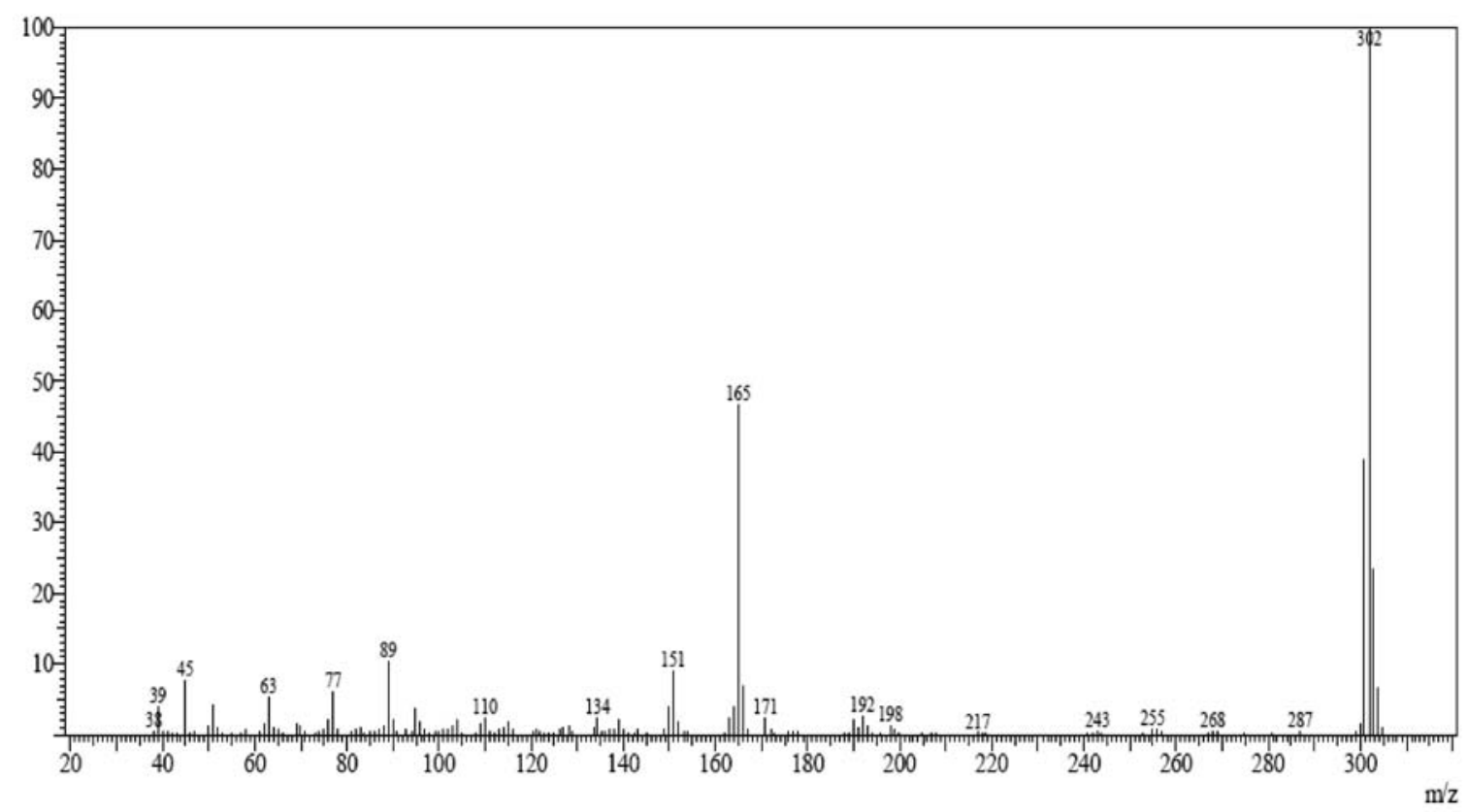

Figure S45. Mass spectrum (70 eV) of compound 4,5-diphenyl-2-(thiophen-3-yl)-1 $H$-imidazole (8k). 


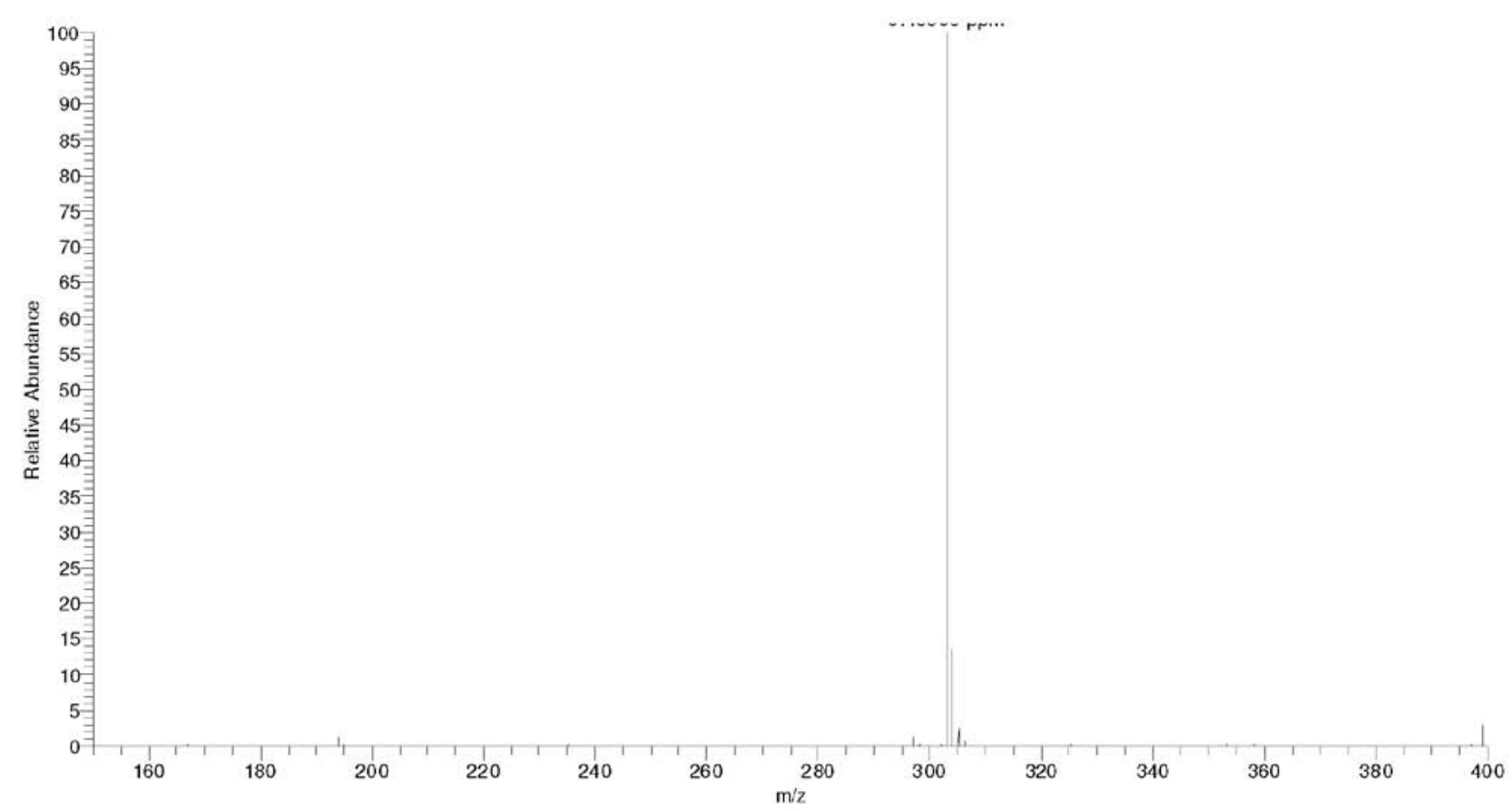

Figure S46. HRMS (ESI +) of compound 4,5-diphenyl-2-(thiophen-3-yl)-1H-imidazole (8k).
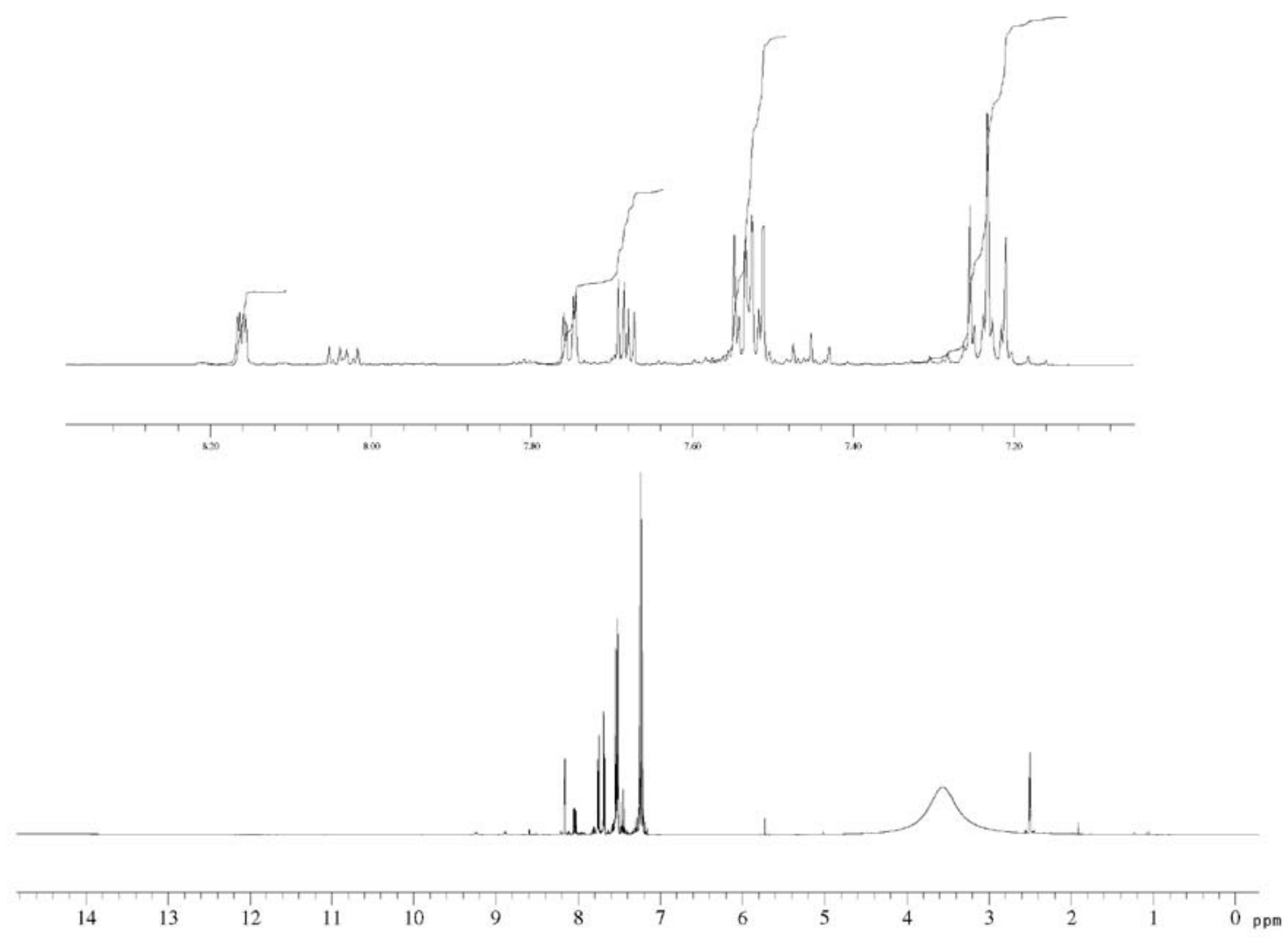

Figure S47. ${ }^{1} \mathrm{H}$ NMR spectrum (400 MHz, DMSO- $d_{6}$ ) of compound 4,5-bis(4-methoxyphenyl)-2-(thiophen-3-yl)-1H-imidazole (81). 


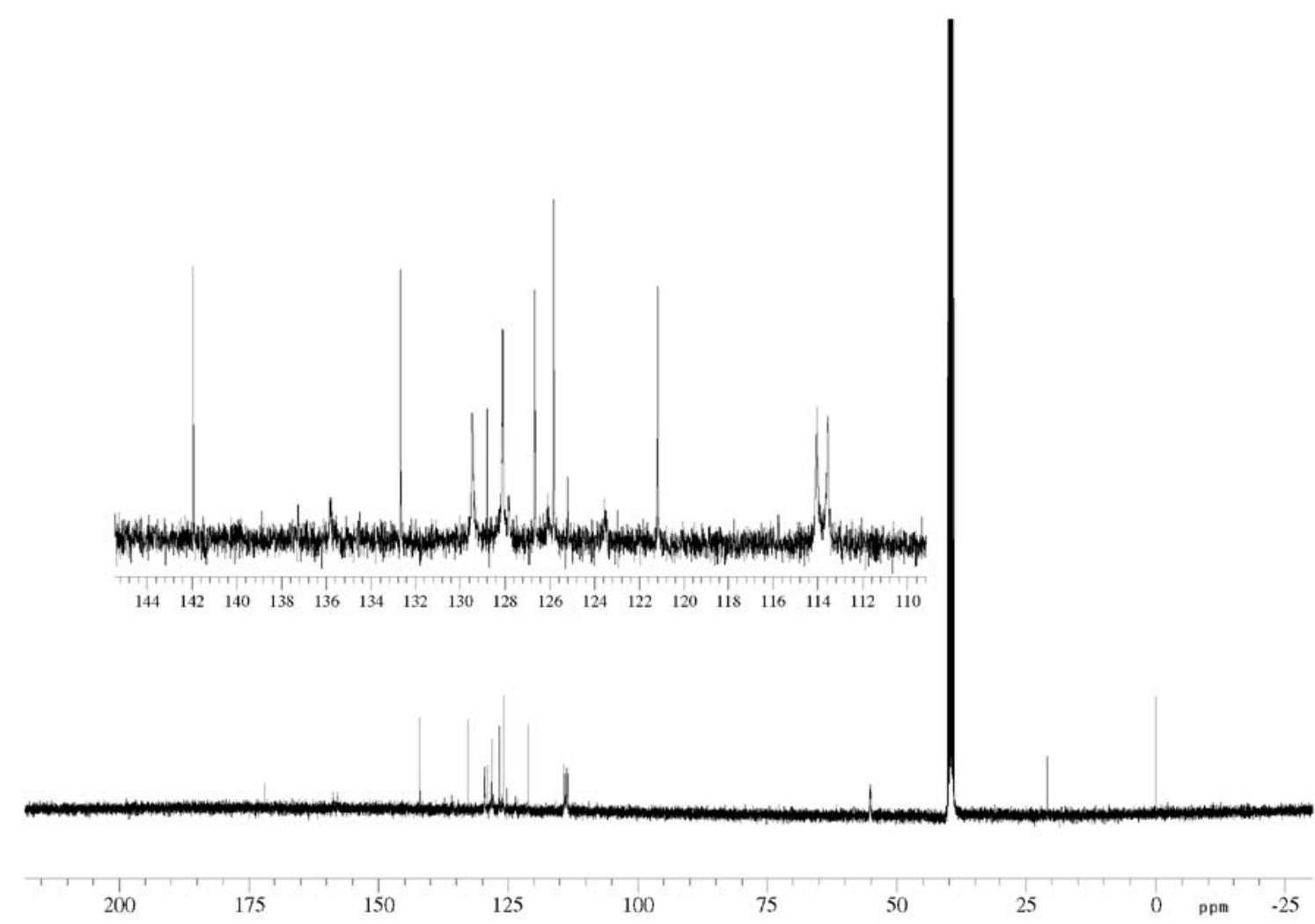

Figure S48. ${ }^{13} \mathrm{C}$ NMR spectrum (100 MHz, DMSO- $d_{6}$ ) of compound 4,5-bis(4-methoxyphenyl)-2-(thiophen-3-yl)-1H-imidazole (81).

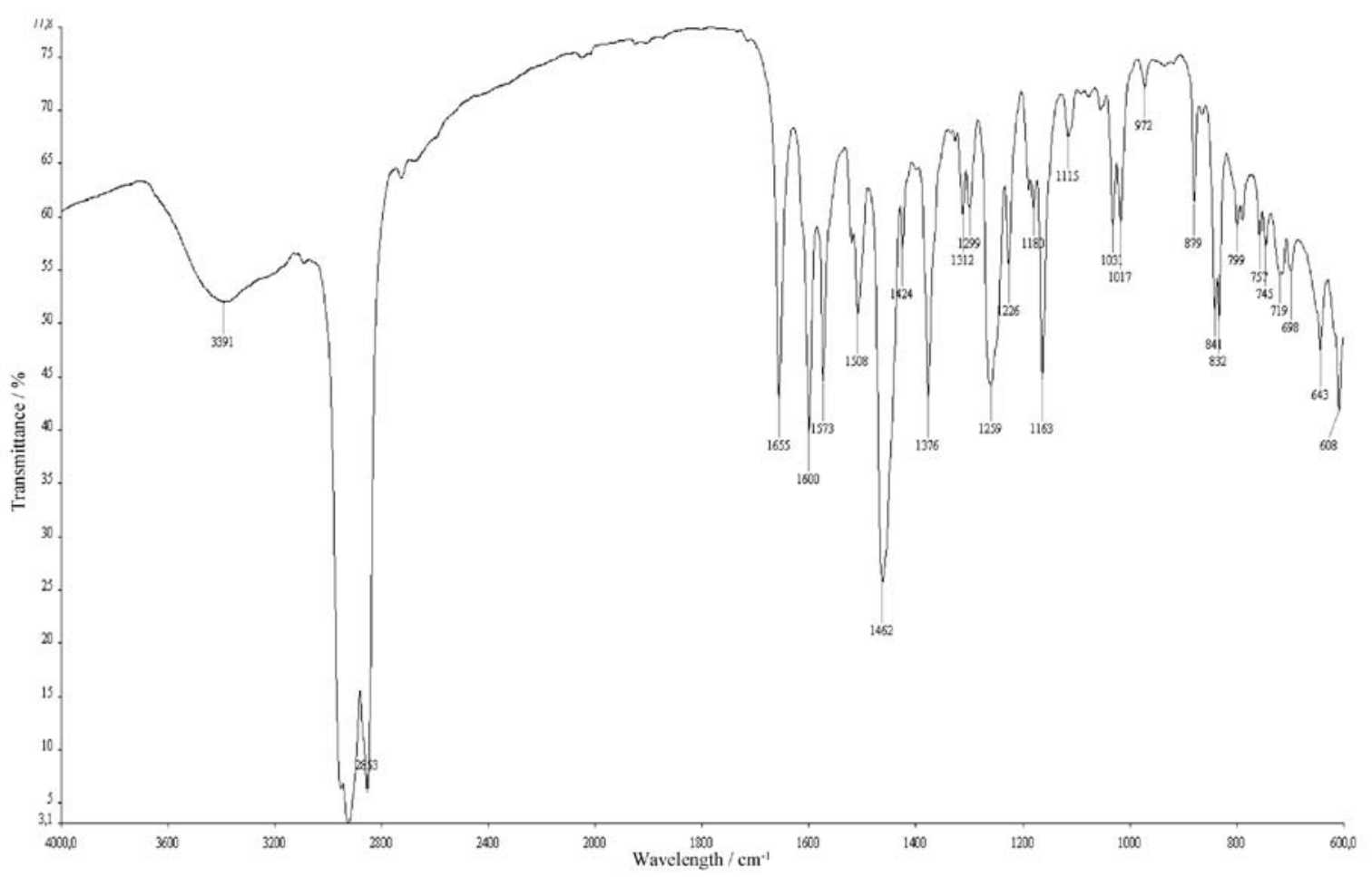

Figure S49. IR spectrum (Nujol) of compound 4,5-bis(4-methoxyphenyl)-2-(thiophen-3-yl)-1H-imidazole (8I). 


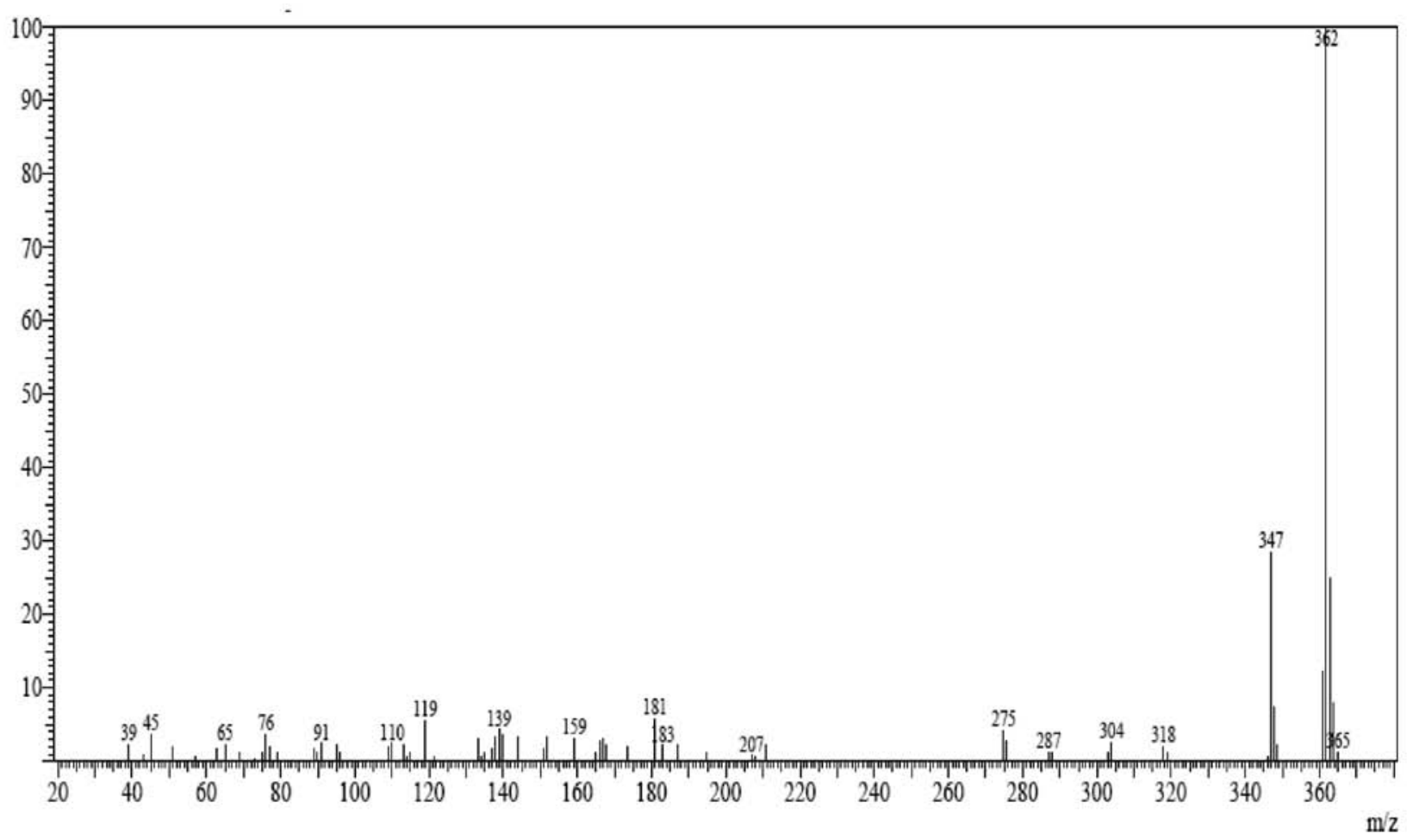

Figure S50. Mass spectrum (70 eV) of compound 4,5-bis(4-methoxyphenyl)-2-(thiophen-3-yl)-1H-imidazole (81).

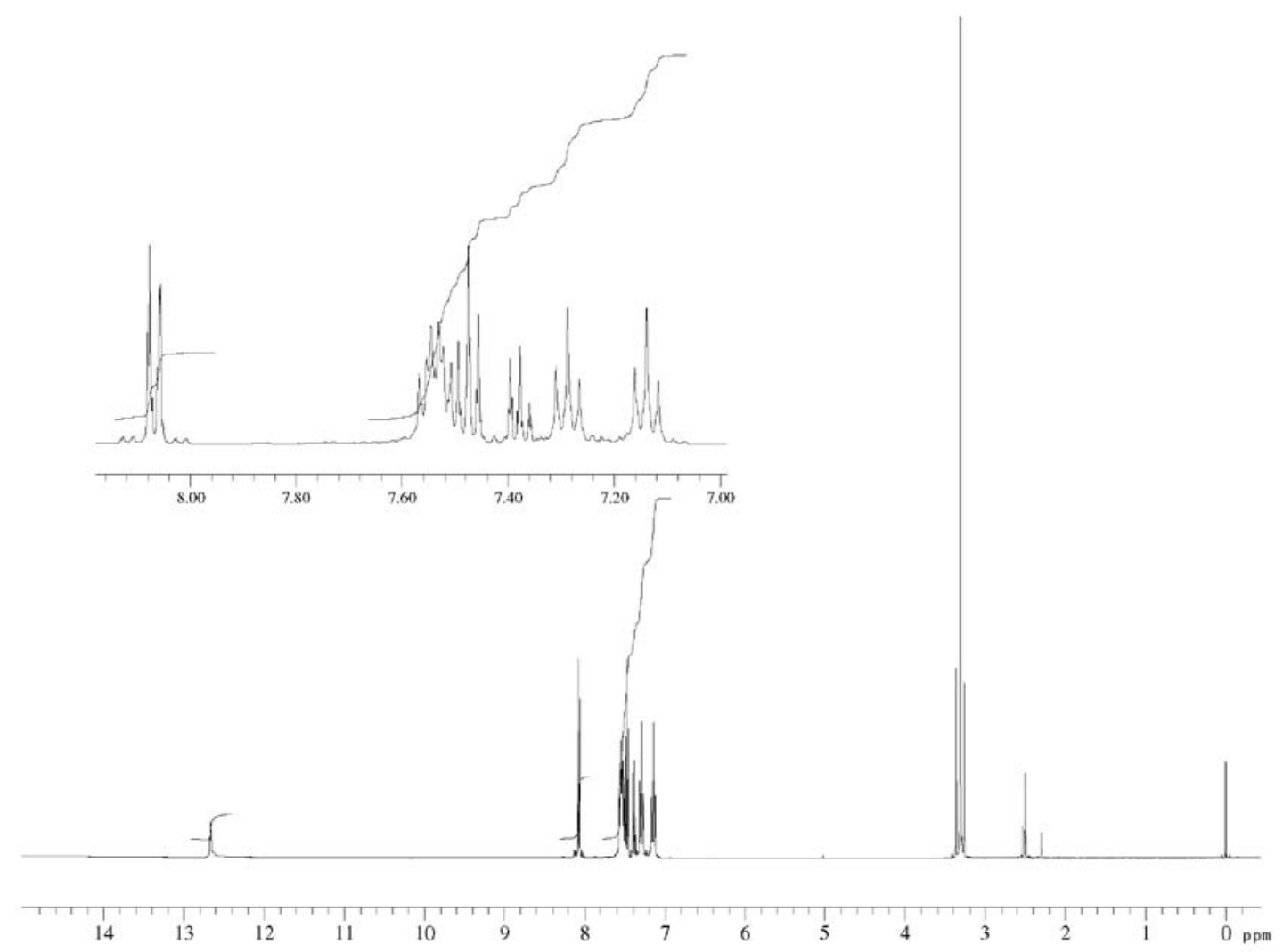

Figure S51. ${ }^{1} \mathrm{H}$ NMR spectrum (400 MHz, DMSO- $d_{6}$ ) of compound 4,5-bis(4-fluorophenyl)-2-phenyl-1 $H$-imidazole (8m). 


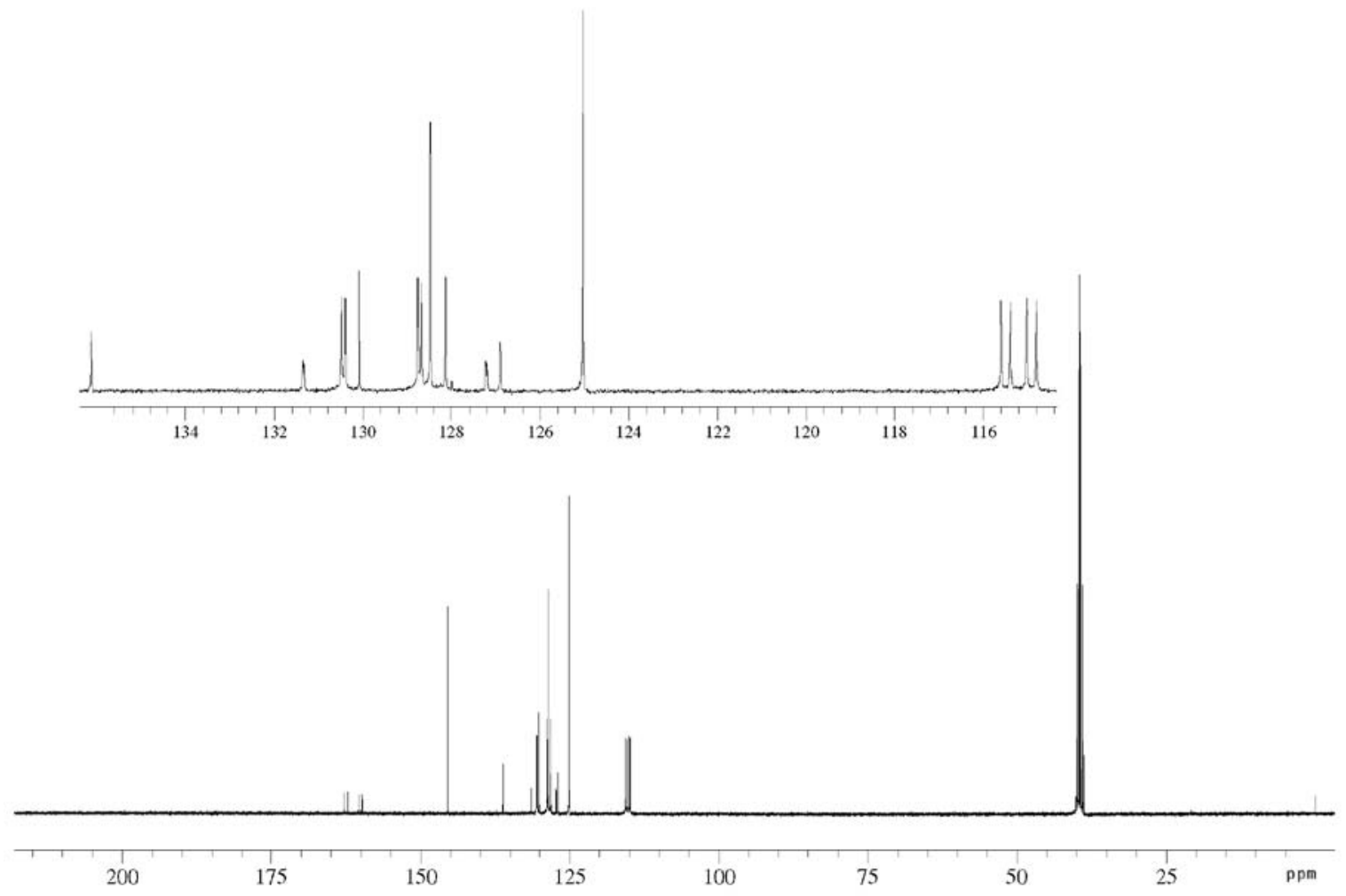

Figure S52. ${ }^{13} \mathrm{C}$ NMR spectrum (100 MHz, DMSO- $d_{6}$ ) of compound 4,5-bis(4-fluorophenyl)-2-phenyl- $1 H$-imidazole (8m).

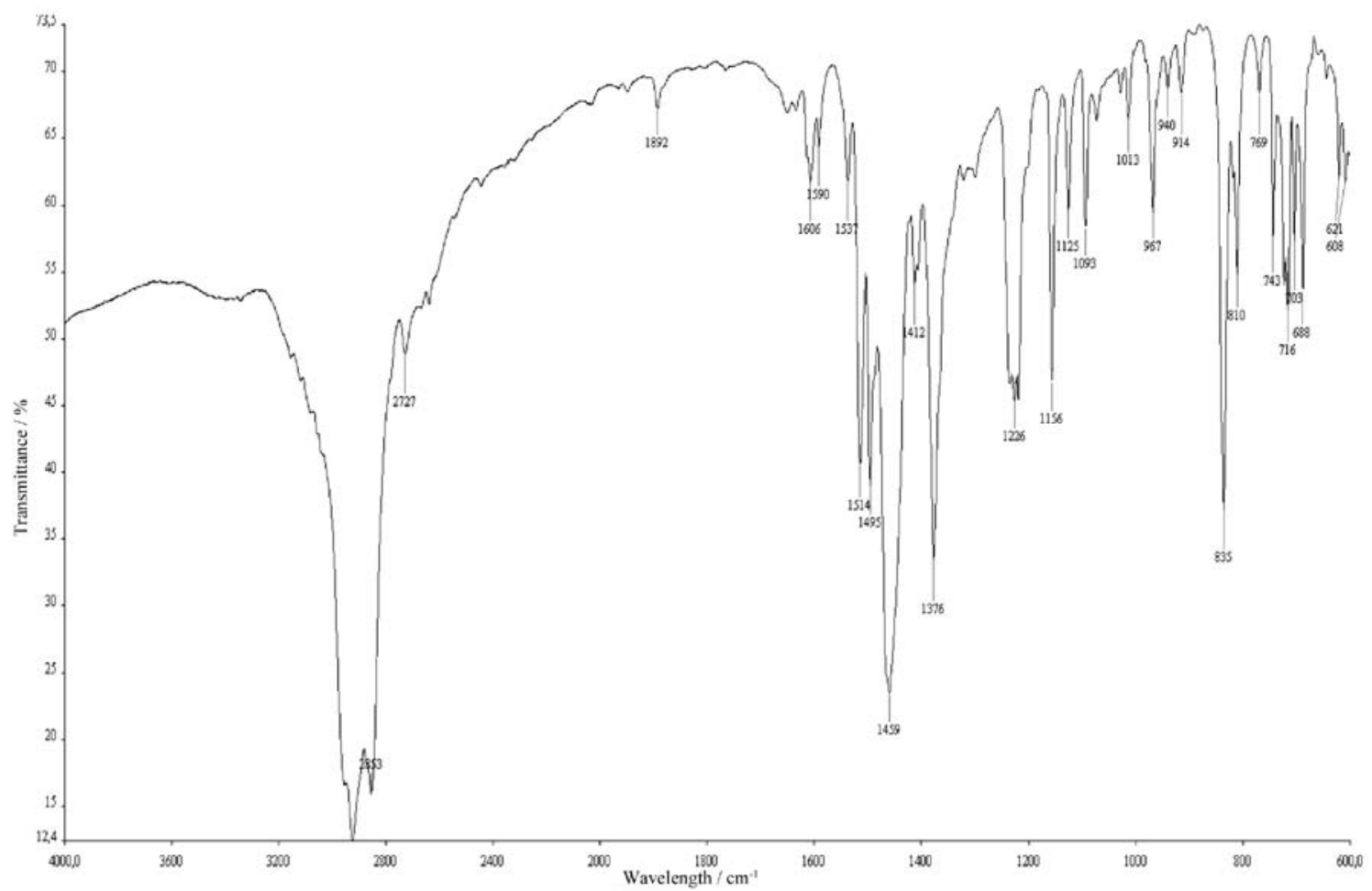

Figure S53. IR spectrum (Nujol) of compound 4,5-bis(4-fluorophenyl)-2-phenyl-1 $H$-imidazole (8m). 


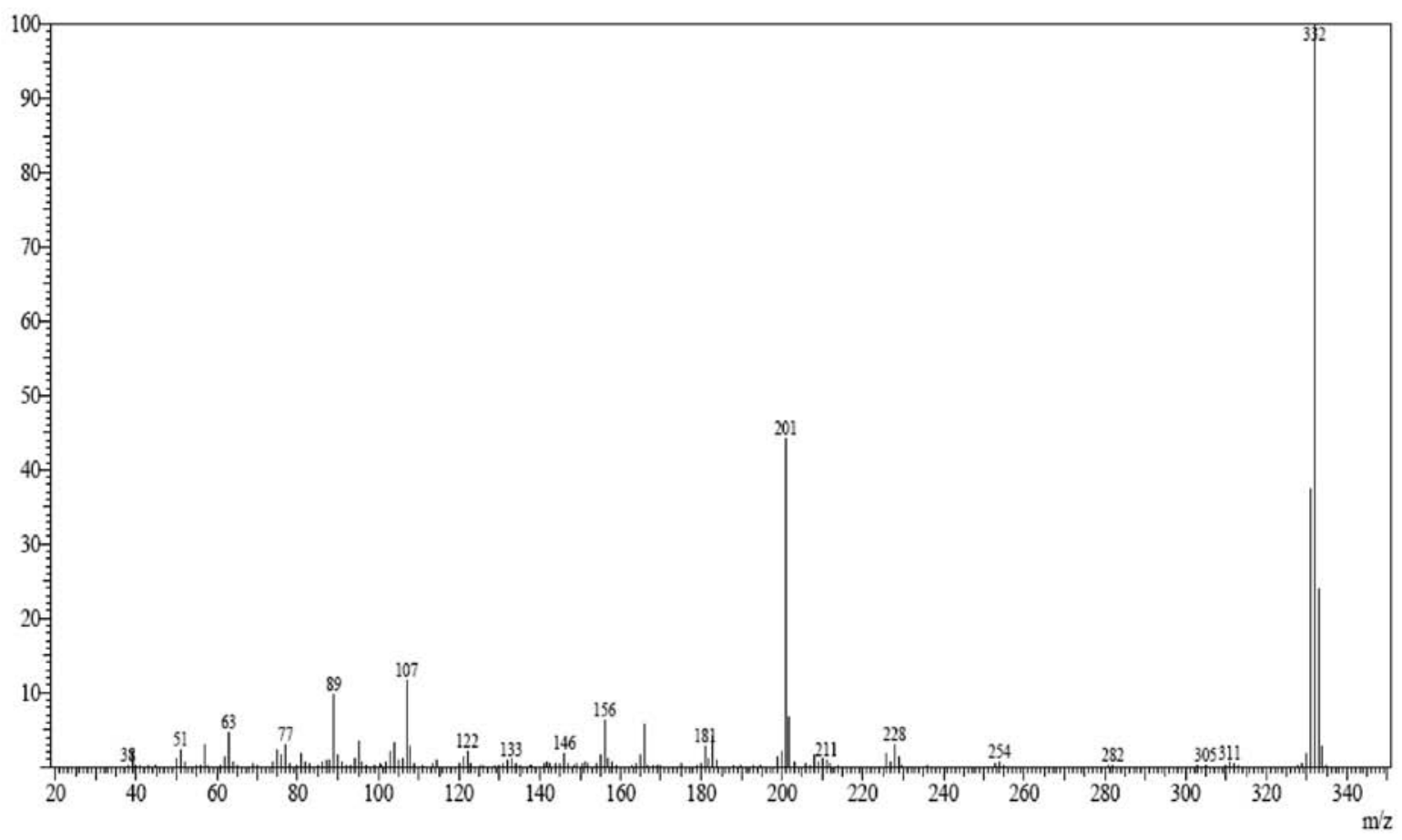

Figure S54. Mass spectrum (70 eV) of compound 4,5-bis(4-fluorophenyl)-2-phenyl- $1 H$-imidazole (8m).

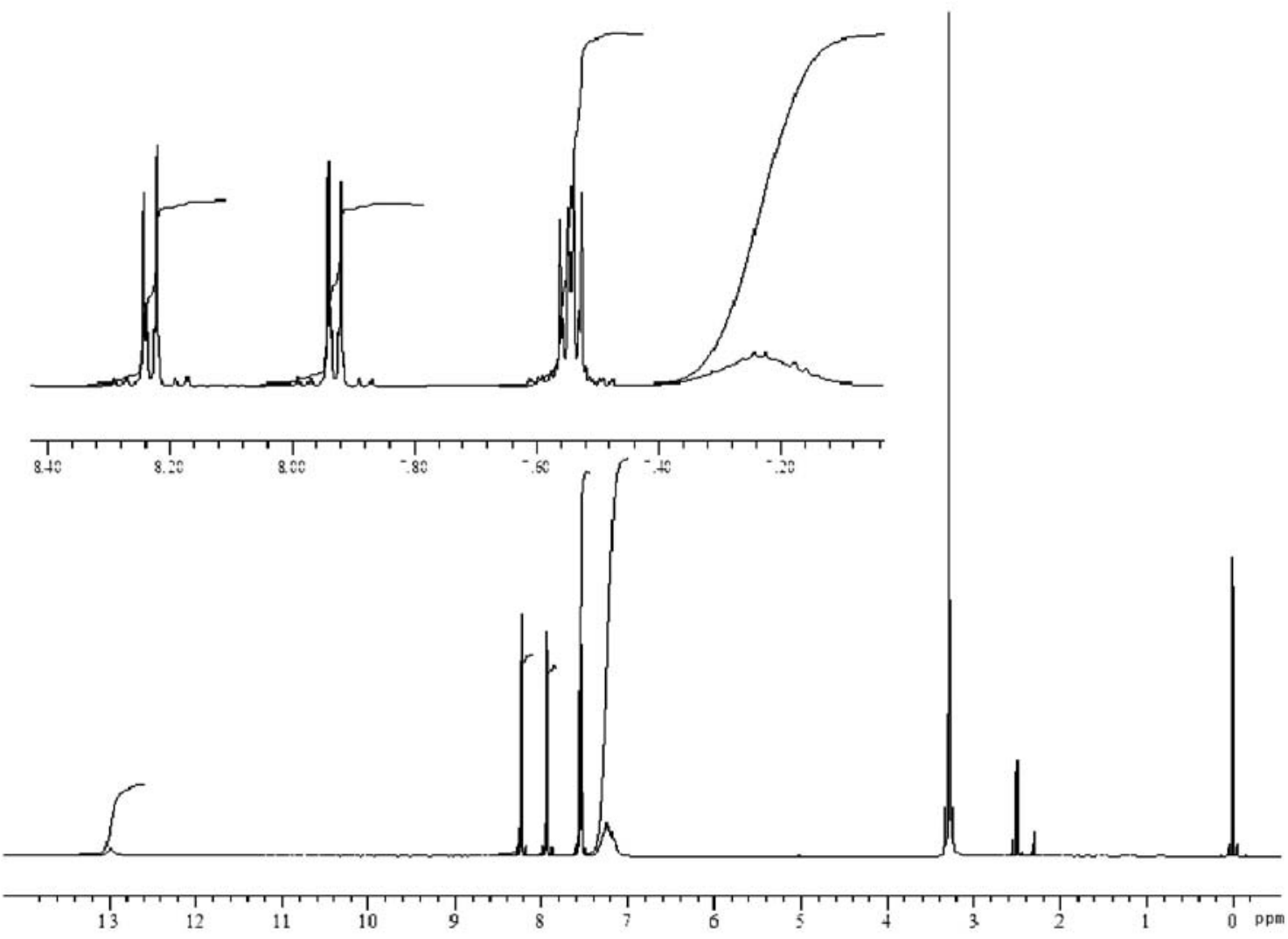

Figure S55. ${ }^{1} \mathrm{H}$ NMR spectrum (400 MHz, DMSO- $d_{6}$ ) of compound 4-[4,5-bis(4-fluorophenyl)- $1 H$-imidazol-2-yl]benzonitrile (8n). 


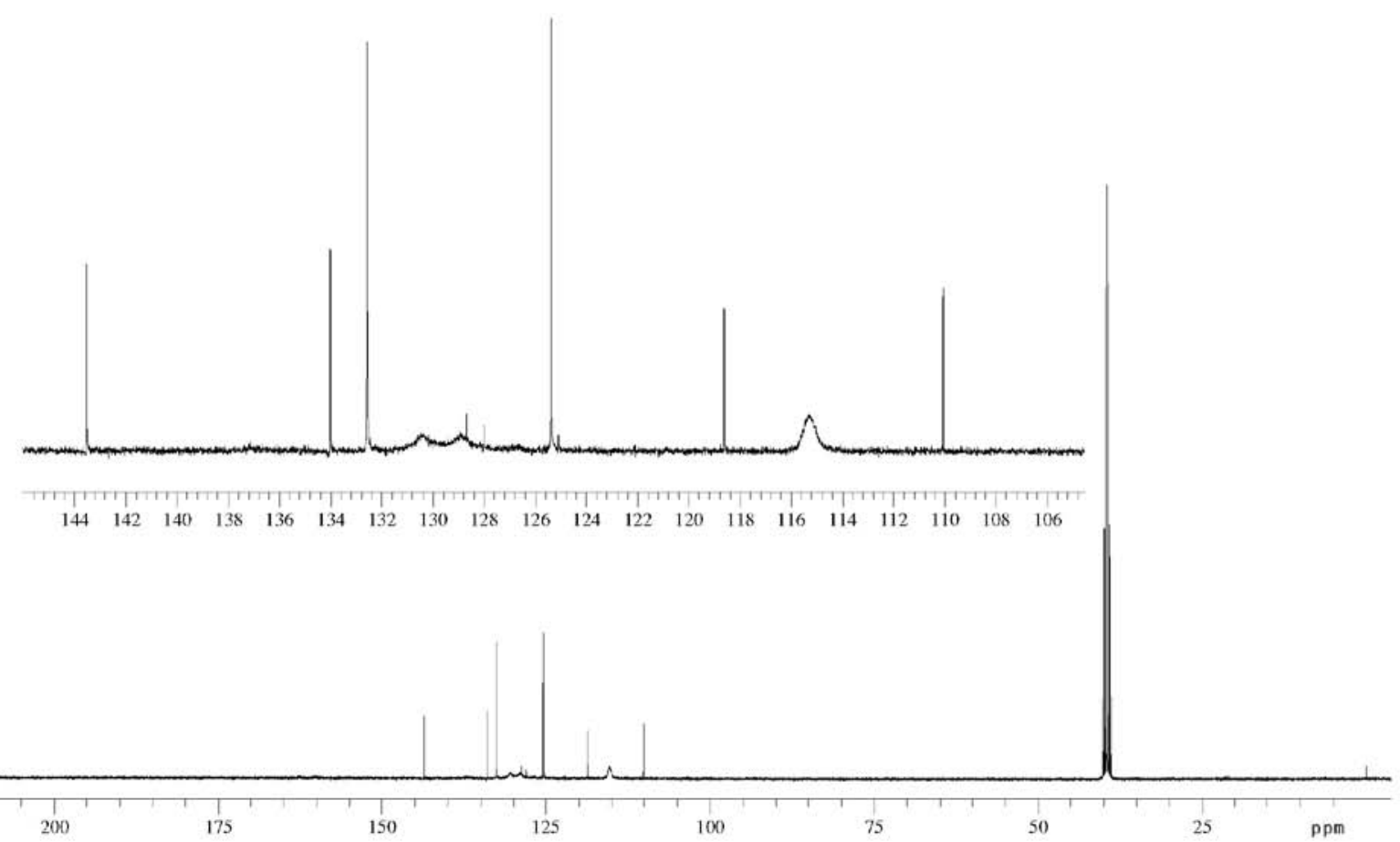

Figure S56. ${ }^{13} \mathrm{C}$ NMR spectrum (100 MHz, DMSO- $d_{6}$ ) of compound 4-[4,5-bis(4-fluorophenyl)-1 $H$-imidazol-2-yl]benzonitrile (8n).

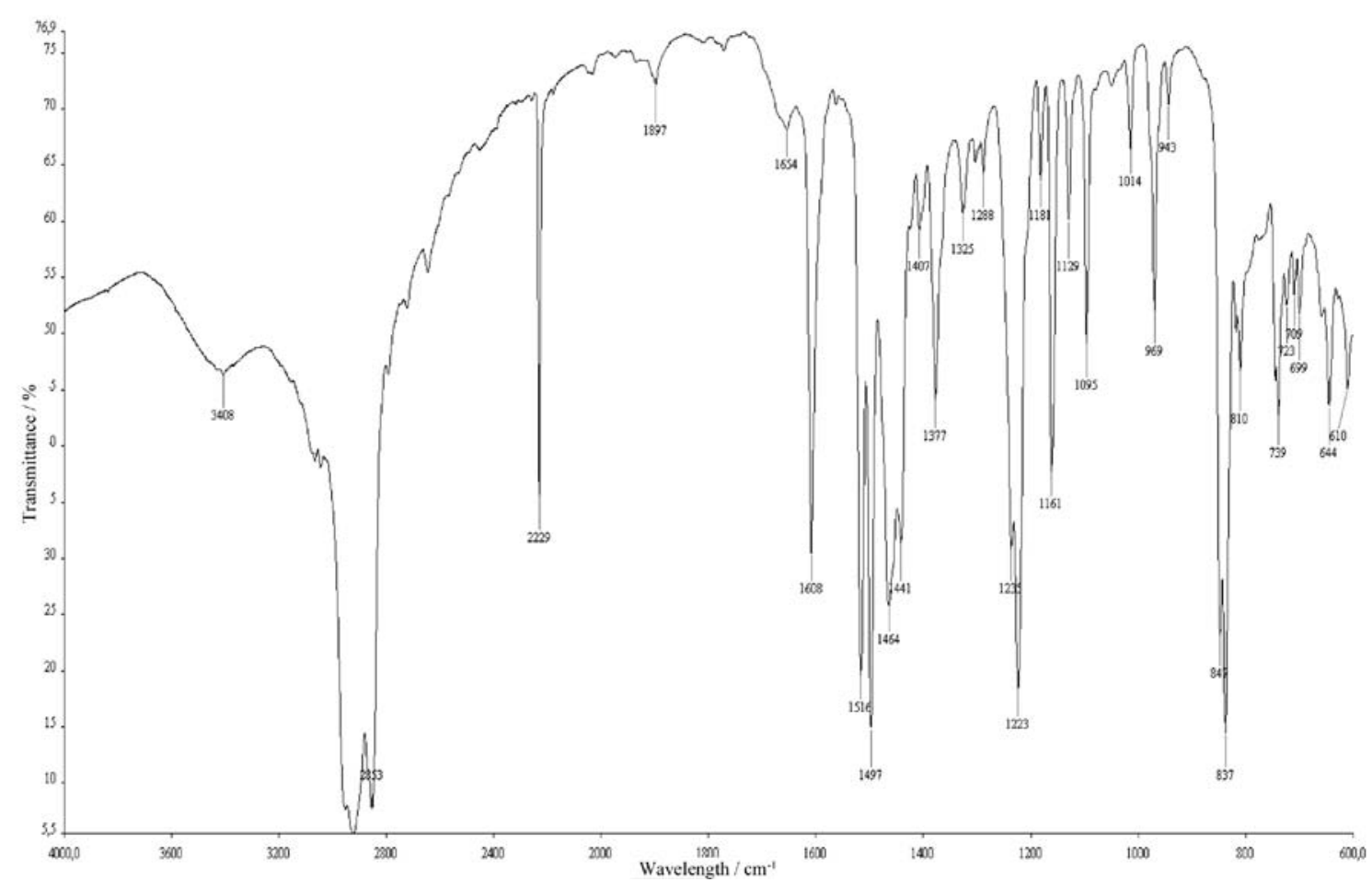

Figure S57. IR spectrum (Nujol) of compound 4-[4,5-bis(4-fluorophenyl)-1H-imidazol-2-yl]benzonitrile (8n). 


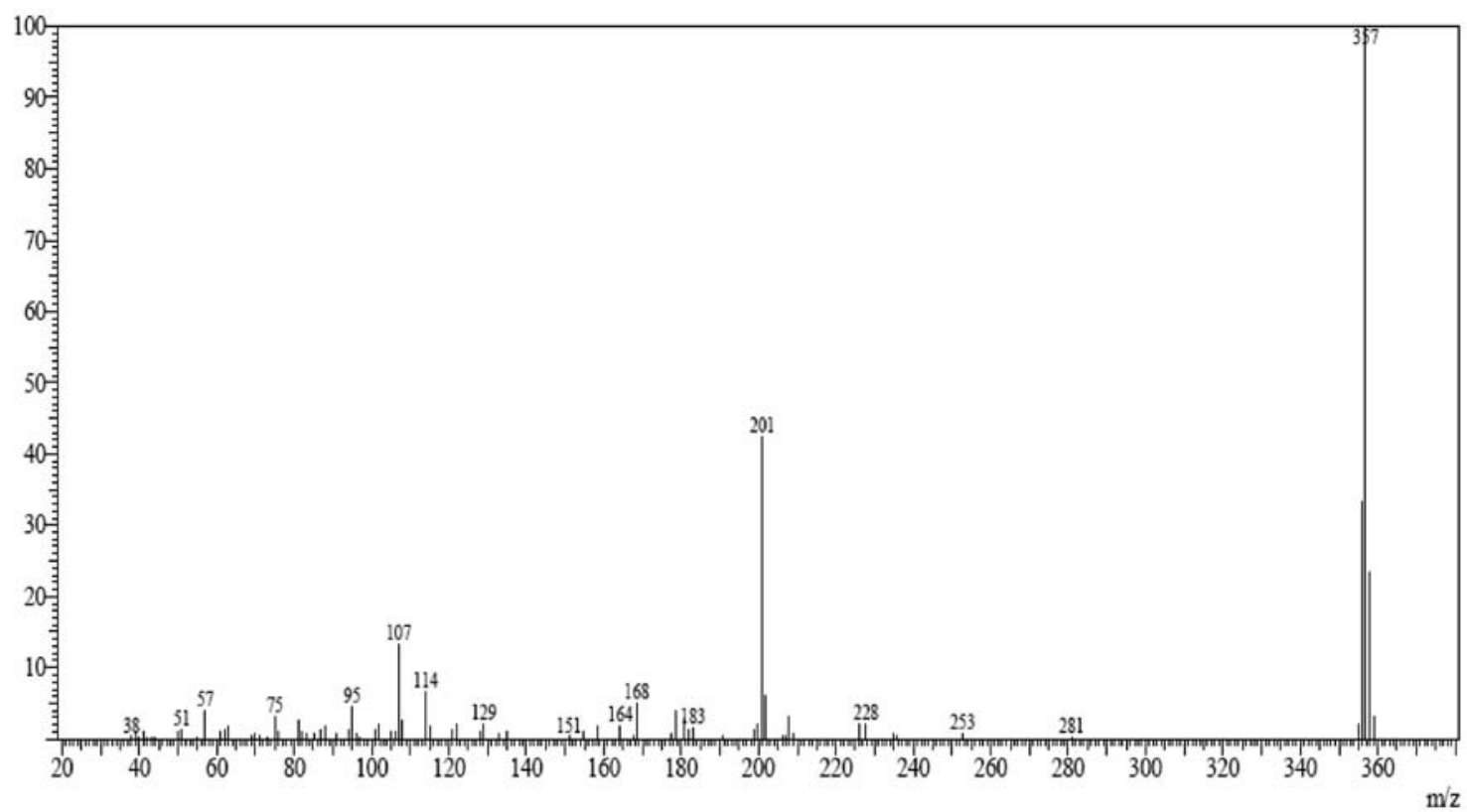

Figure S58. Mass spectrum (70 eV) of compound 4-[4,5-bis(4-fluorophenyl)- $1 H$-imidazol-2-yl]benzonitrile (8n).

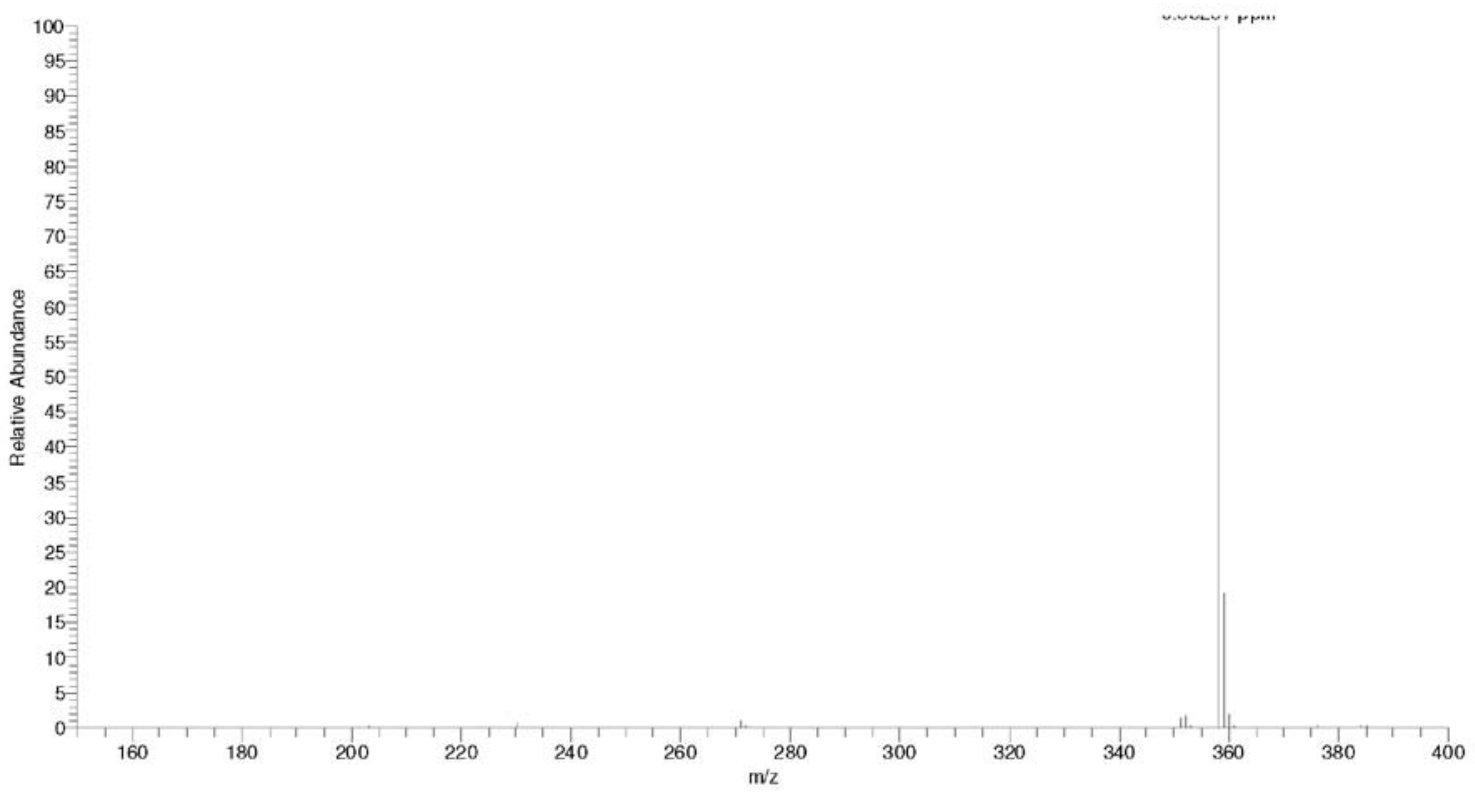

Figure S59. HRMS (ESI +) of compound 4-[4,5-bis(4-fluorophenyl)-1H-imidazol-2-yl]benzonitrile (8n). 


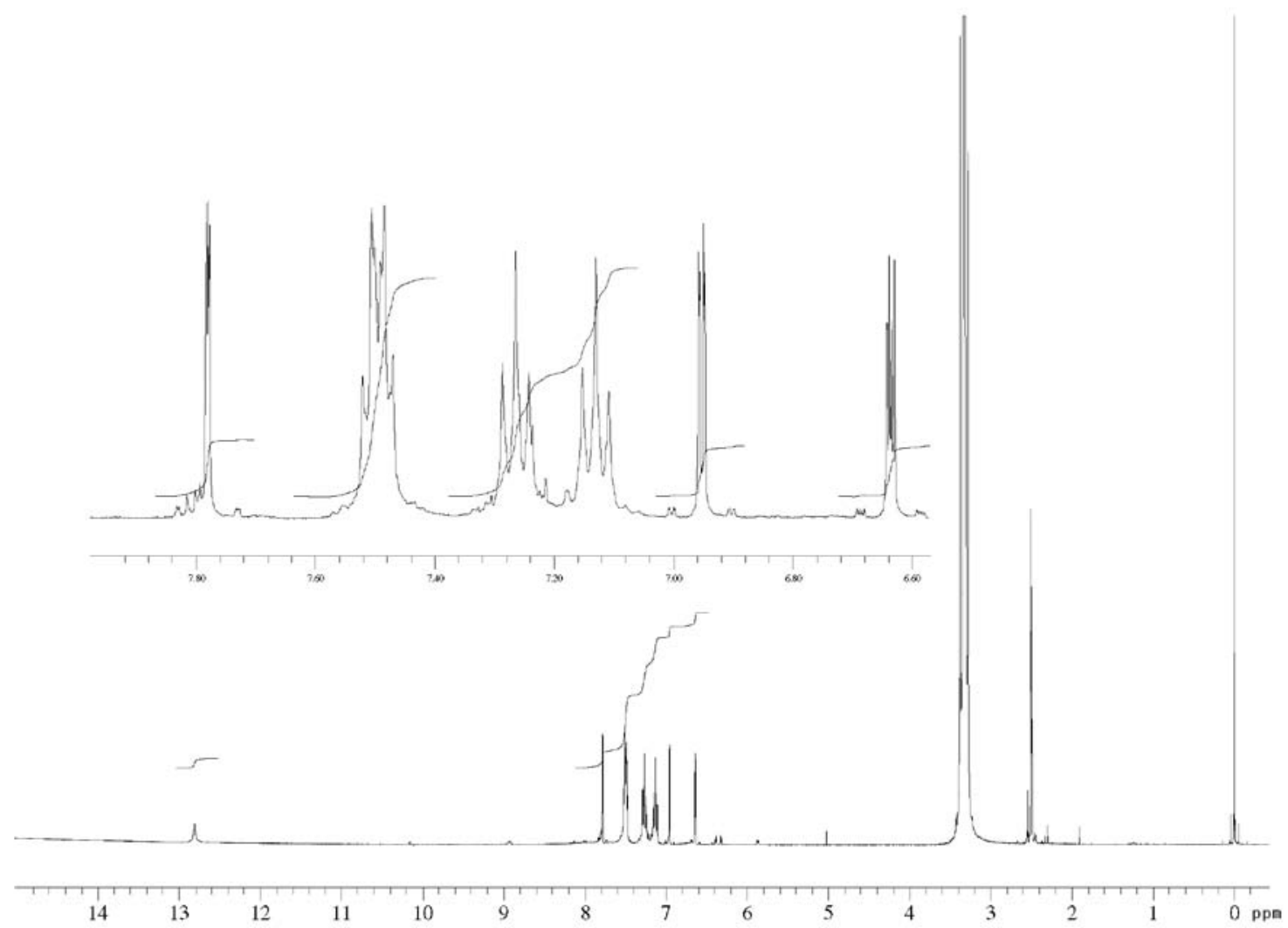

Figure S60. ${ }^{1} \mathrm{H}$ NMR spectrum (400 MHz, DMSO- $d_{6}$ ) of compound 4,5-bis(4-fluorophenyl)-2-(furan-2-yl)-1 $H$-imidazole (8o).

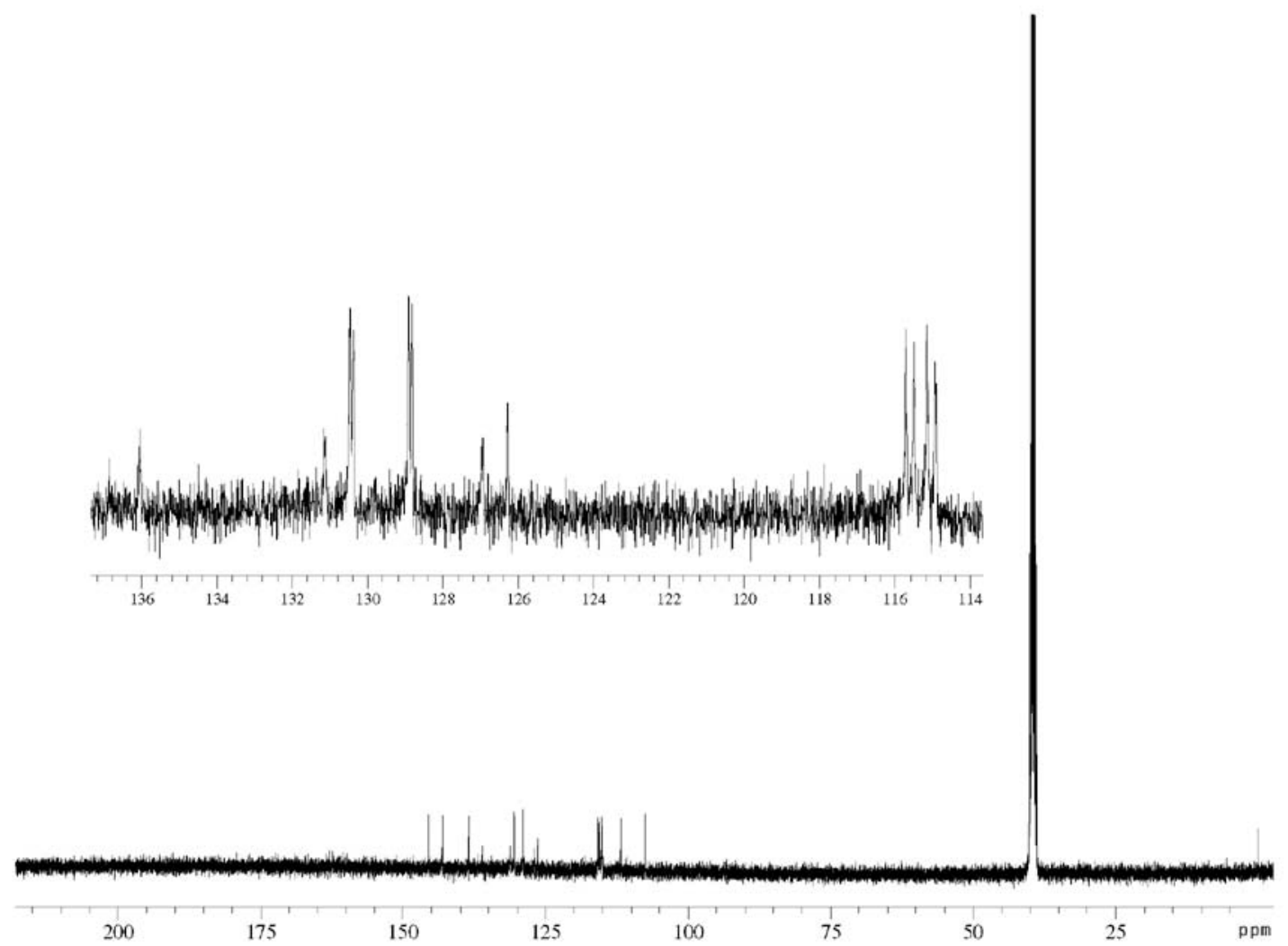

Figure S61. ${ }^{13} \mathrm{C}$ NMR spectrum (100 MHz, DMSO- $d_{6}$ ) of compound 4,5-bis(4-fluorophenyl)-2-(furan-2-yl)-1H-imidazole (8o). 


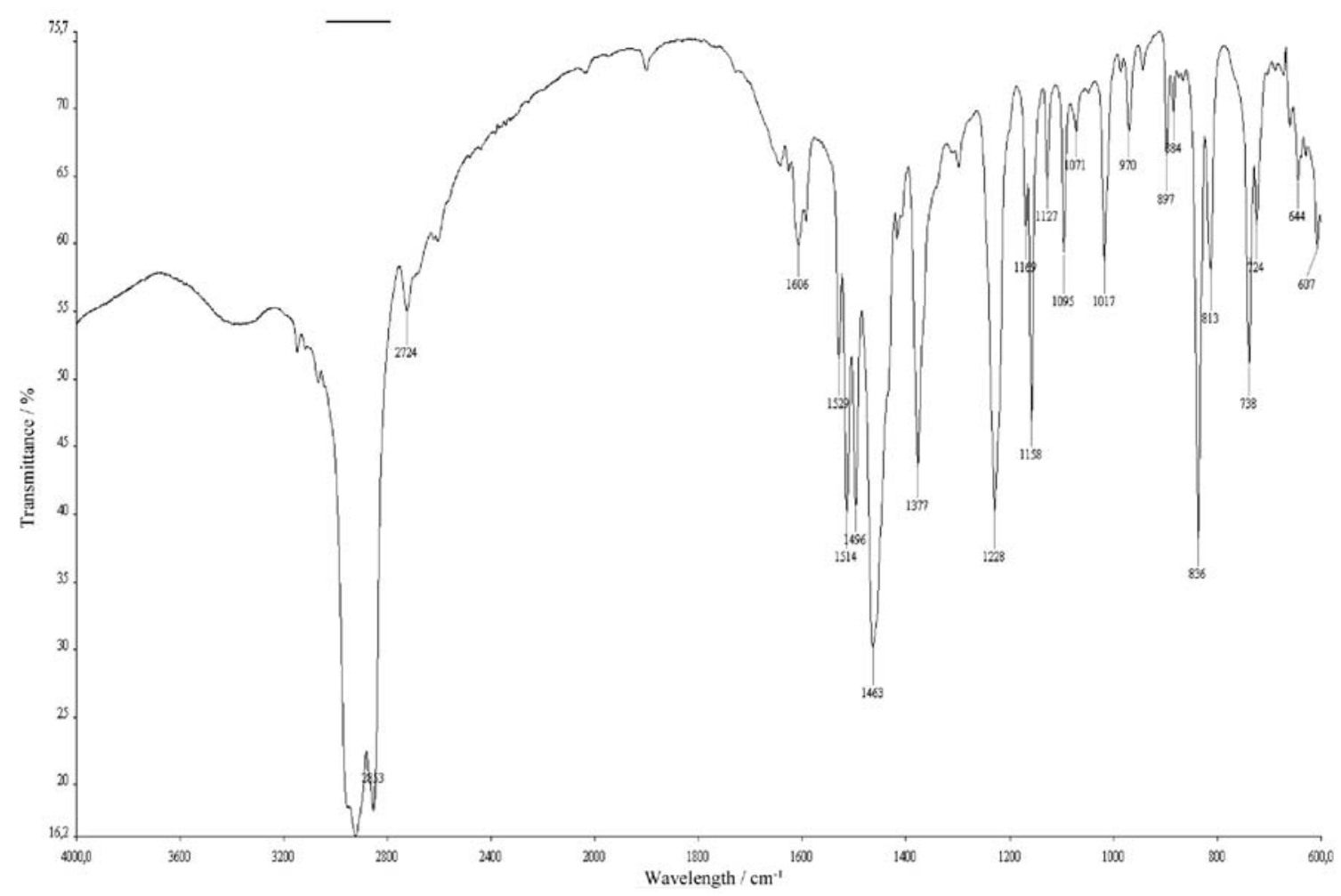

Figure S62. IR spectrum (Nujol) of compound 4,5-bis(4-fluorophenyl)-2-(furan-2-yl)-1H-imidazole (8o).

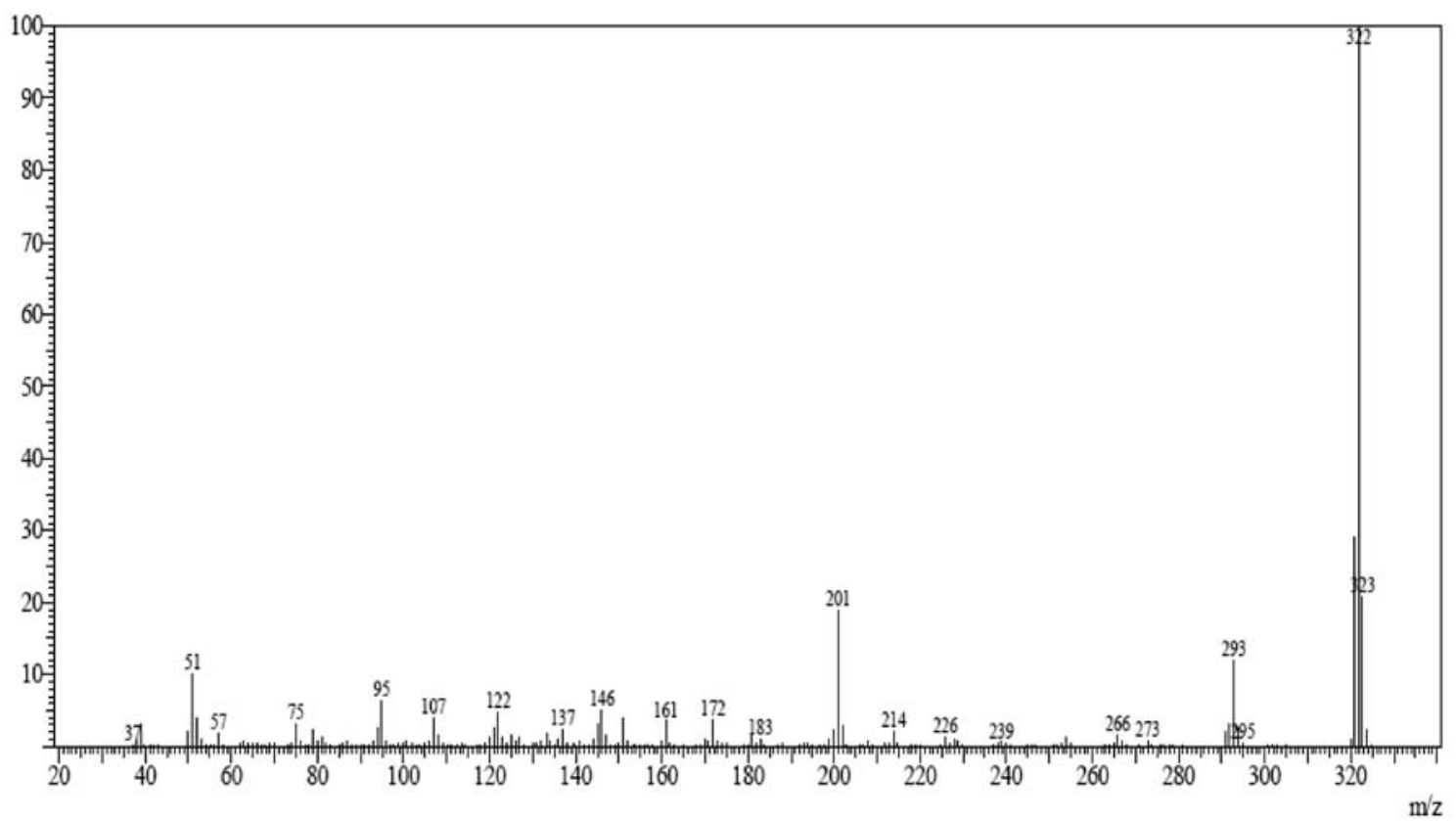

Figure S63. Mass spectrum (70 eV) of compound 4,5-bis(4-fluorophenyl)-2-(furan-2-yl)-1H-imidazole (8o). 


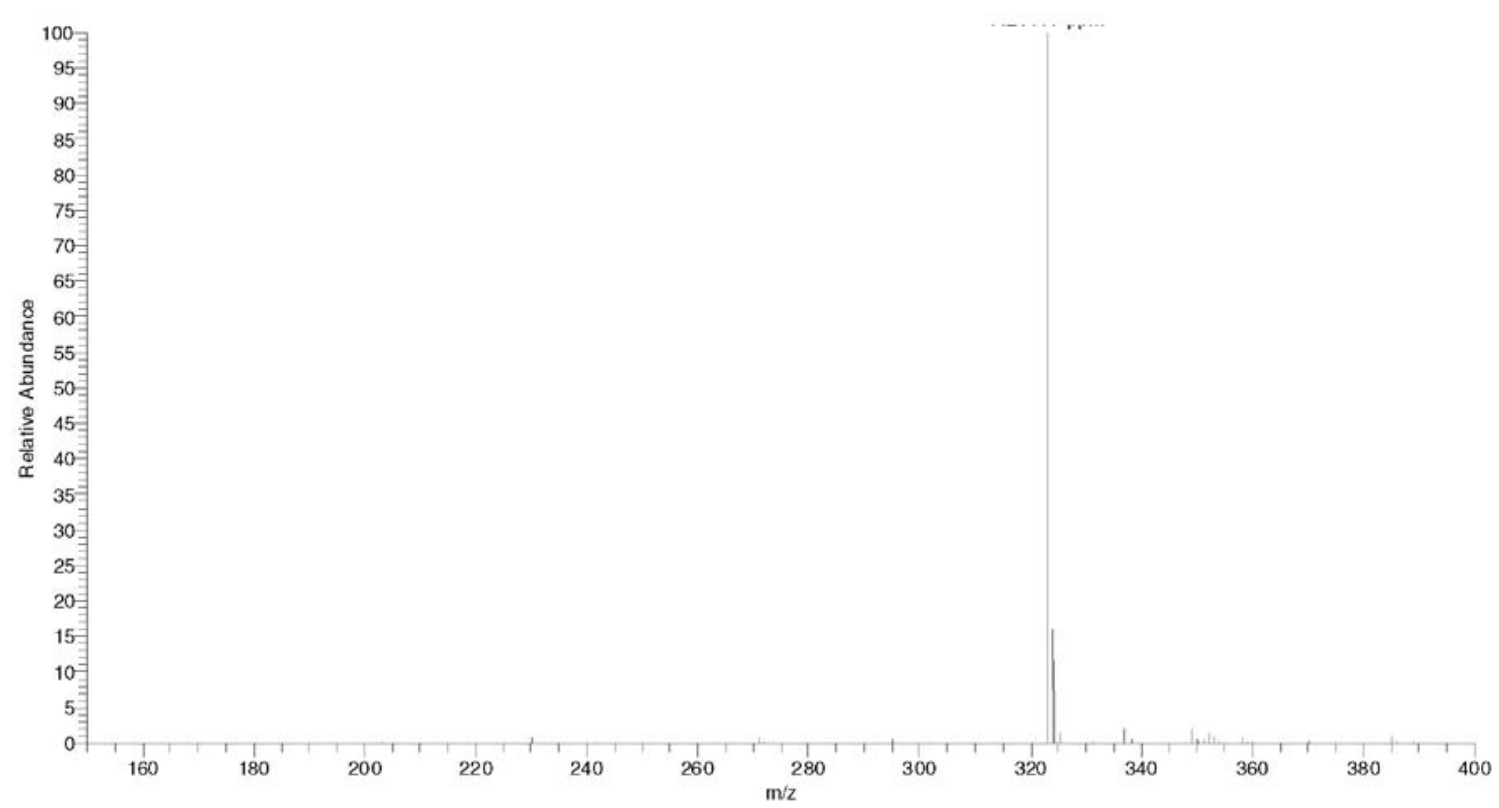

Figure S64. HRMS (ESI +) of compound 4,5-bis(4-fluorophenyl)-2-(furan-2-yl)-1H-imidazole (8o).

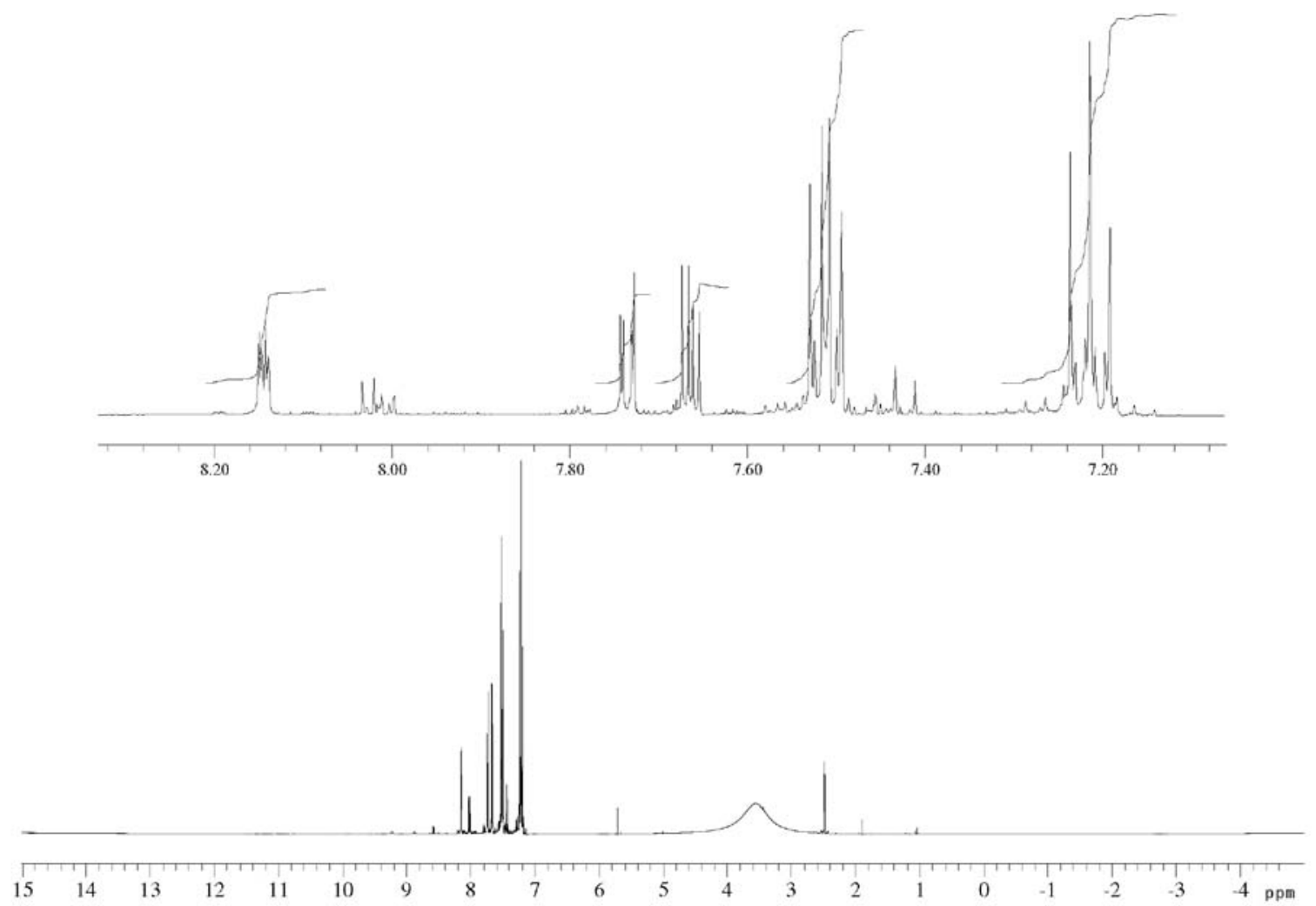

Figure S65. ${ }^{1} \mathrm{H}$ NMR spectrum (400 MHz, DMSO- $d_{6}$ ) of compound 4,5-bis(4-fluorophenyl)-2-(thiophen-3-yl)-1H-imidazole (8p). 


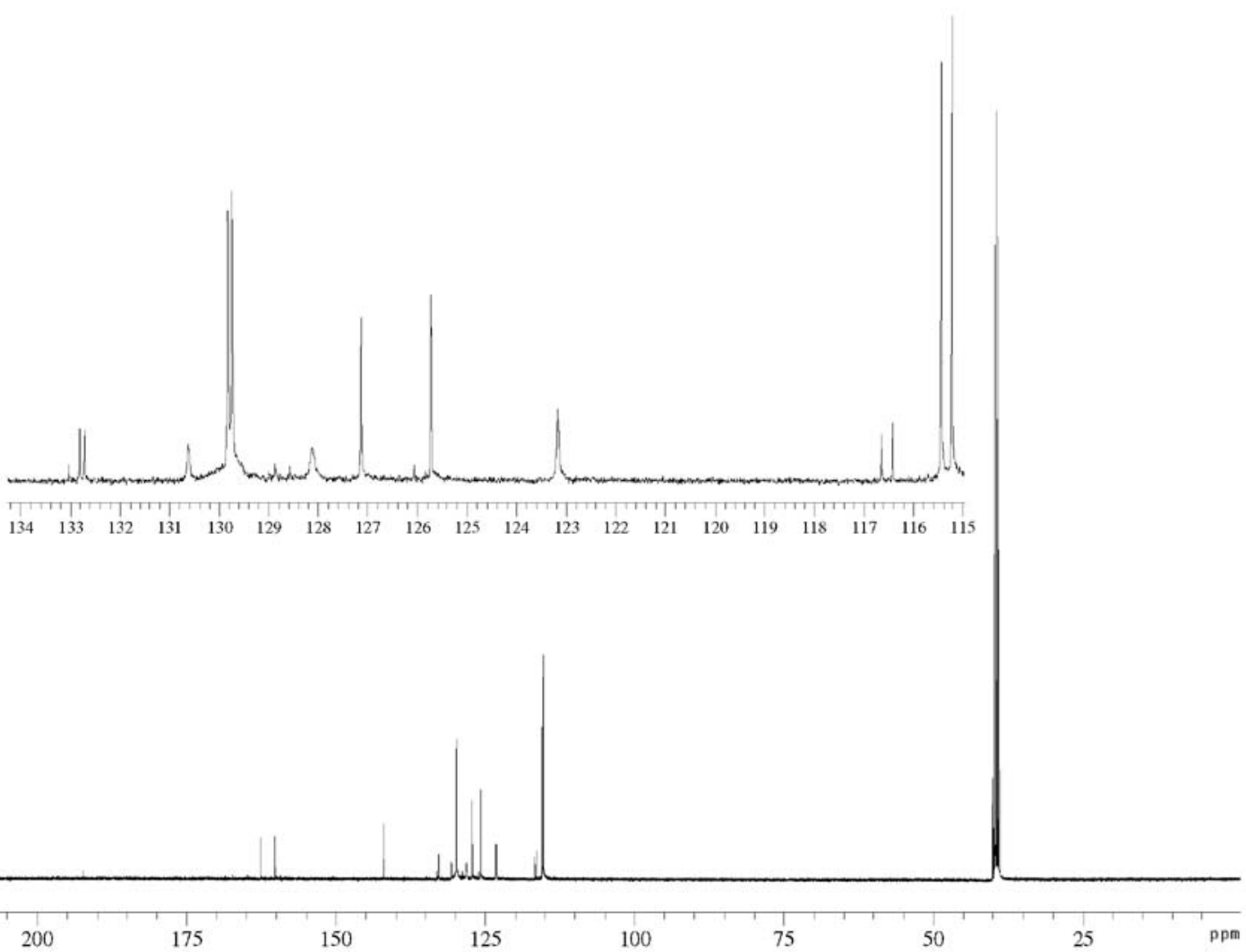

Figure S66. ${ }^{13} \mathrm{C}$ NMR spectrum (100 MHz, DMSO- $d_{6}$ ) of compound 4,5-bis(4-fluorophenyl)-2-(thiophen-3-yl)-1 $H$-imidazole (8p)

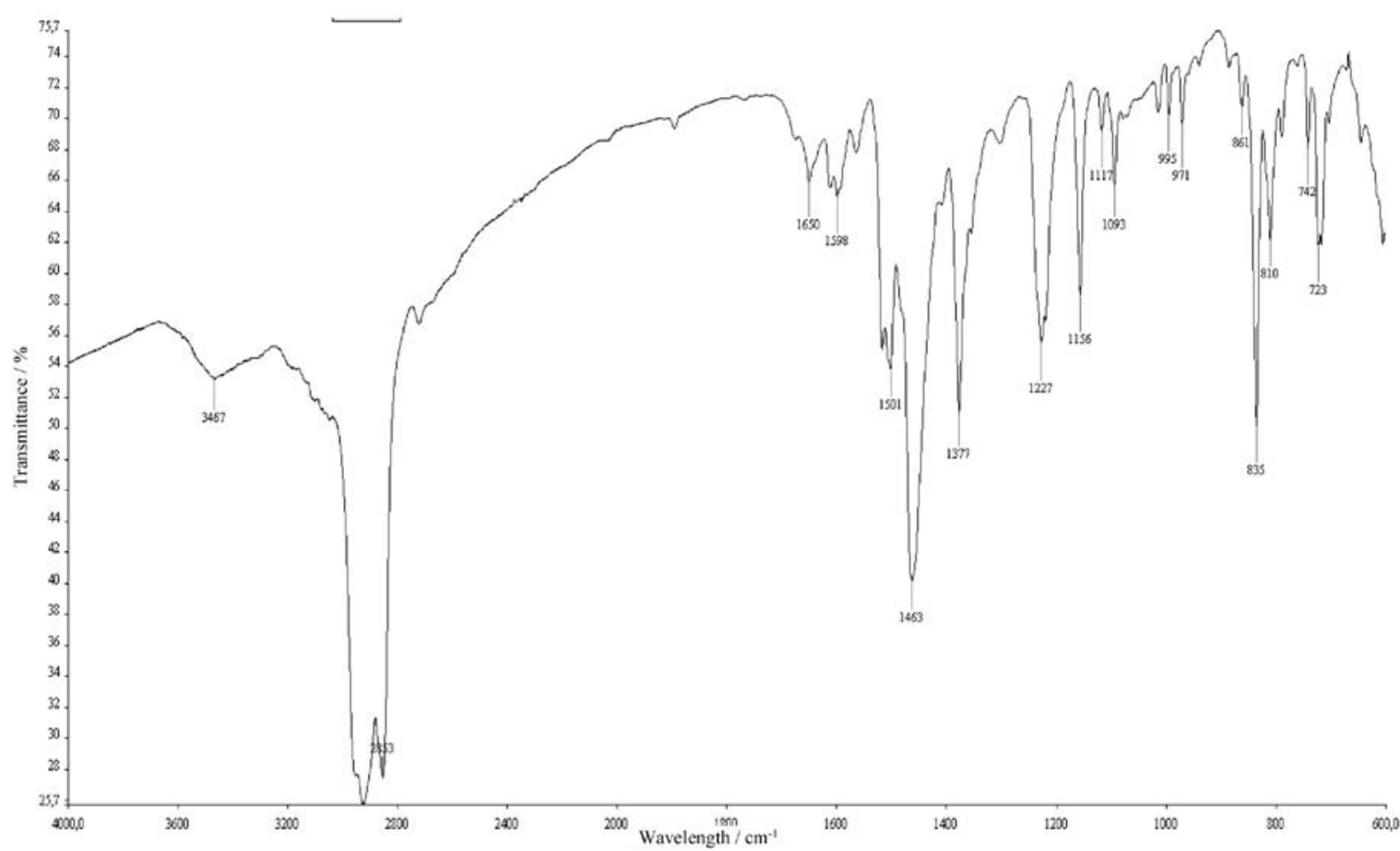

Figure S67. IR spectrum (Nujol) of compound 4,5-bis(4-fluorophenyl)-2-(thiophen-3-yl)-1H-imidazole (8p). 


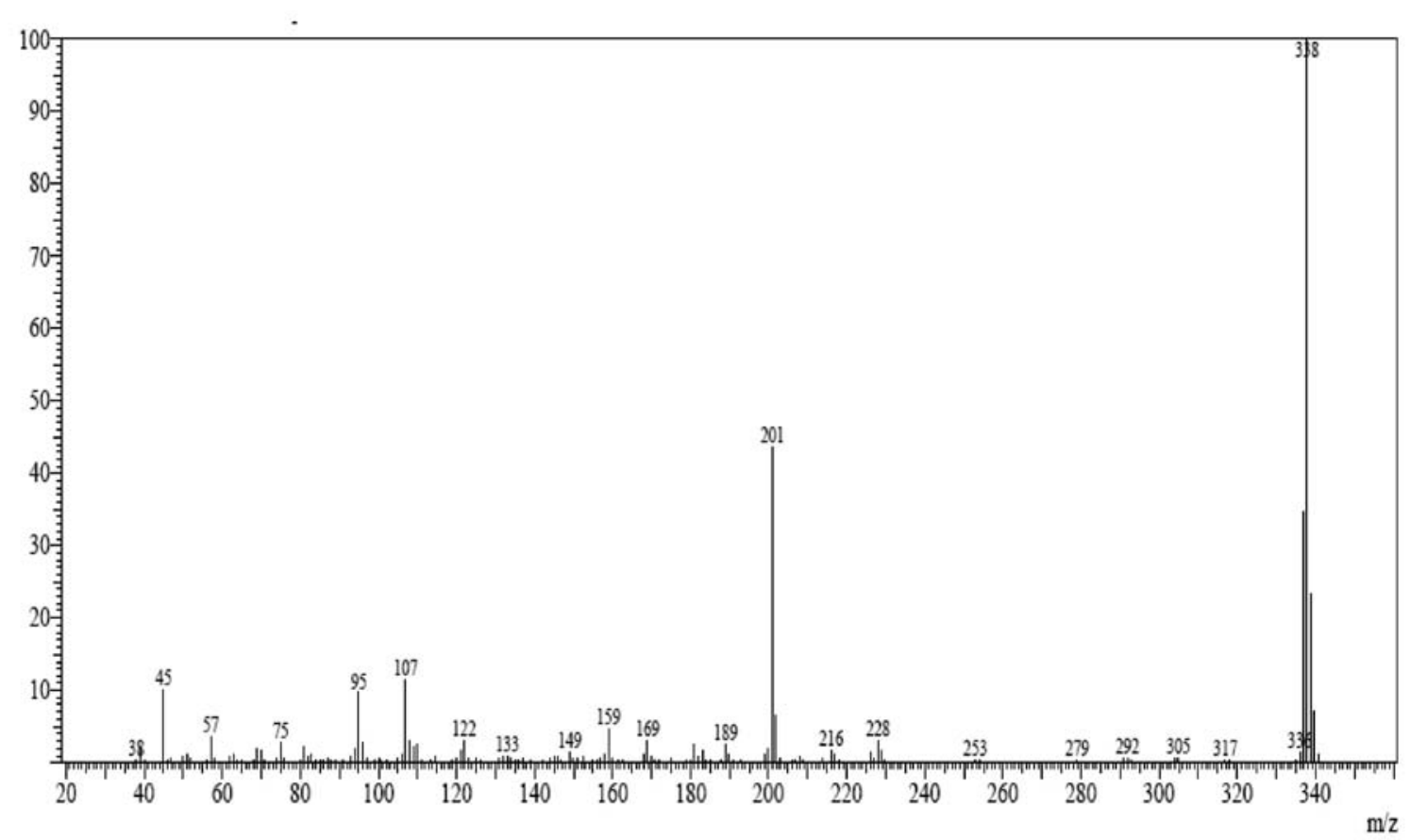

Figure S68. Mass spectrum (70 eV) of compound 4,5-bis(4-fluorophenyl)-2-(thiophen-3-yl)-1 $H$-imidazole (8p).

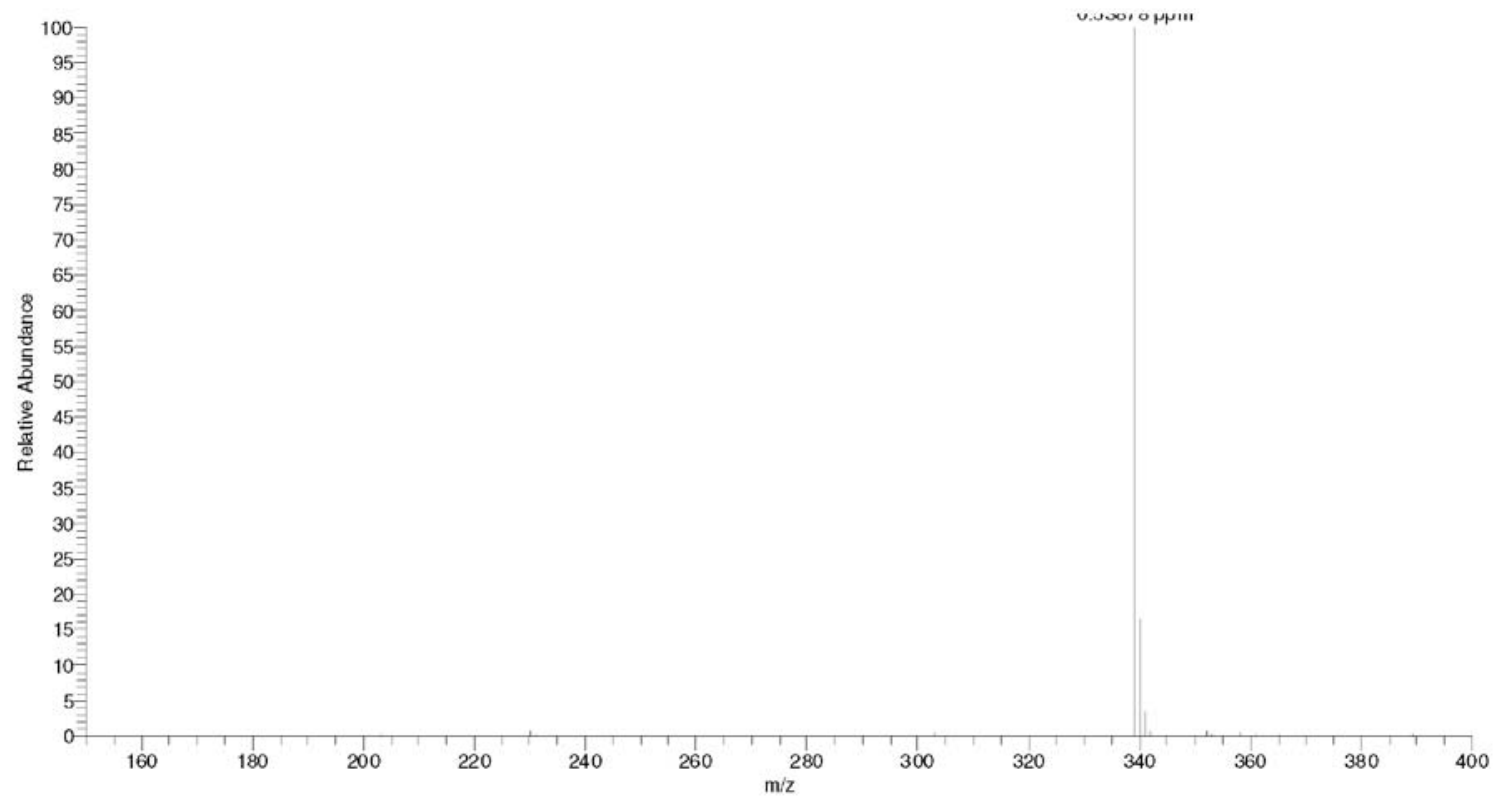

Figure S69. HRMS (ESI +) of compound 4,5-bis(4-fluorophenyl)-2-(thiophen-3-yl)-1H-imidazole (8p). 


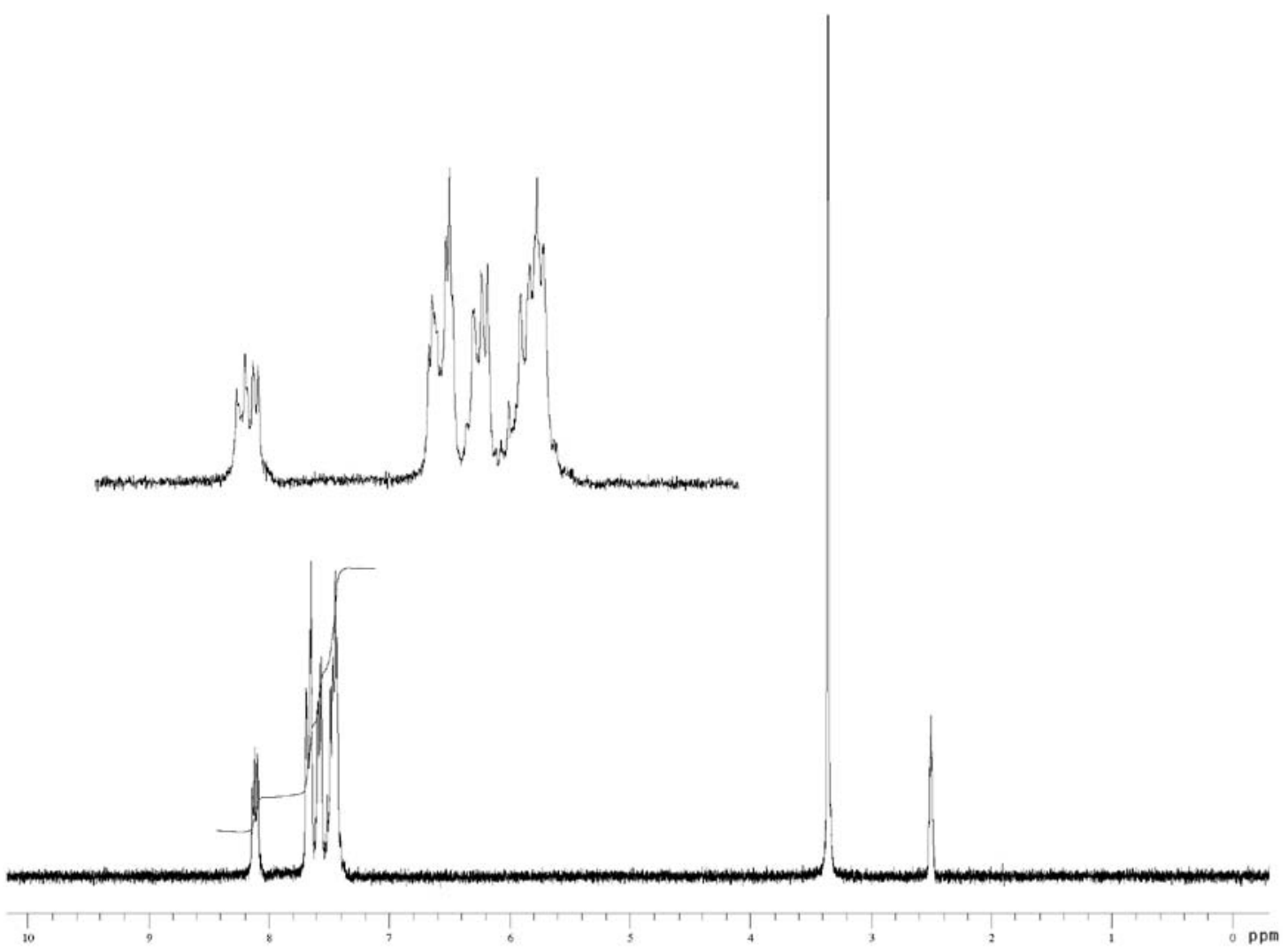

Figure S70. ${ }^{1} \mathrm{H}$ NMR spectrum (200 MHz, DMSO- $d_{6}$ ) of compound 2,4,5-triphenyl-1,3-oxazole (10a).

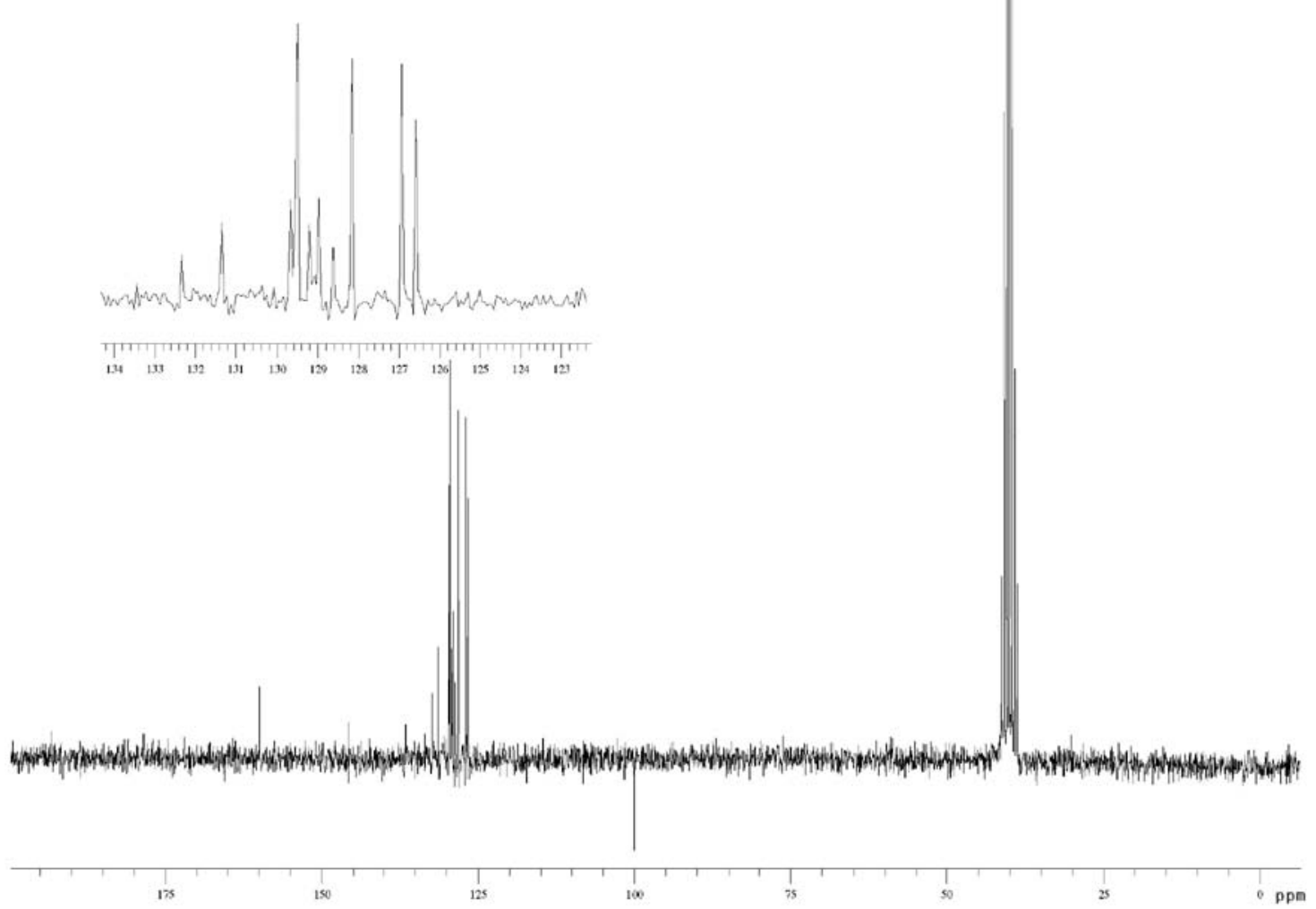

Figure S71. ${ }^{13} \mathrm{C}$ NMR spectrum $\left(50 \mathrm{MHz}\right.$, DMSO- $\left.d_{6}\right)$ of compound 2,4,5-triphenyl-1,3-oxazole (10a). 


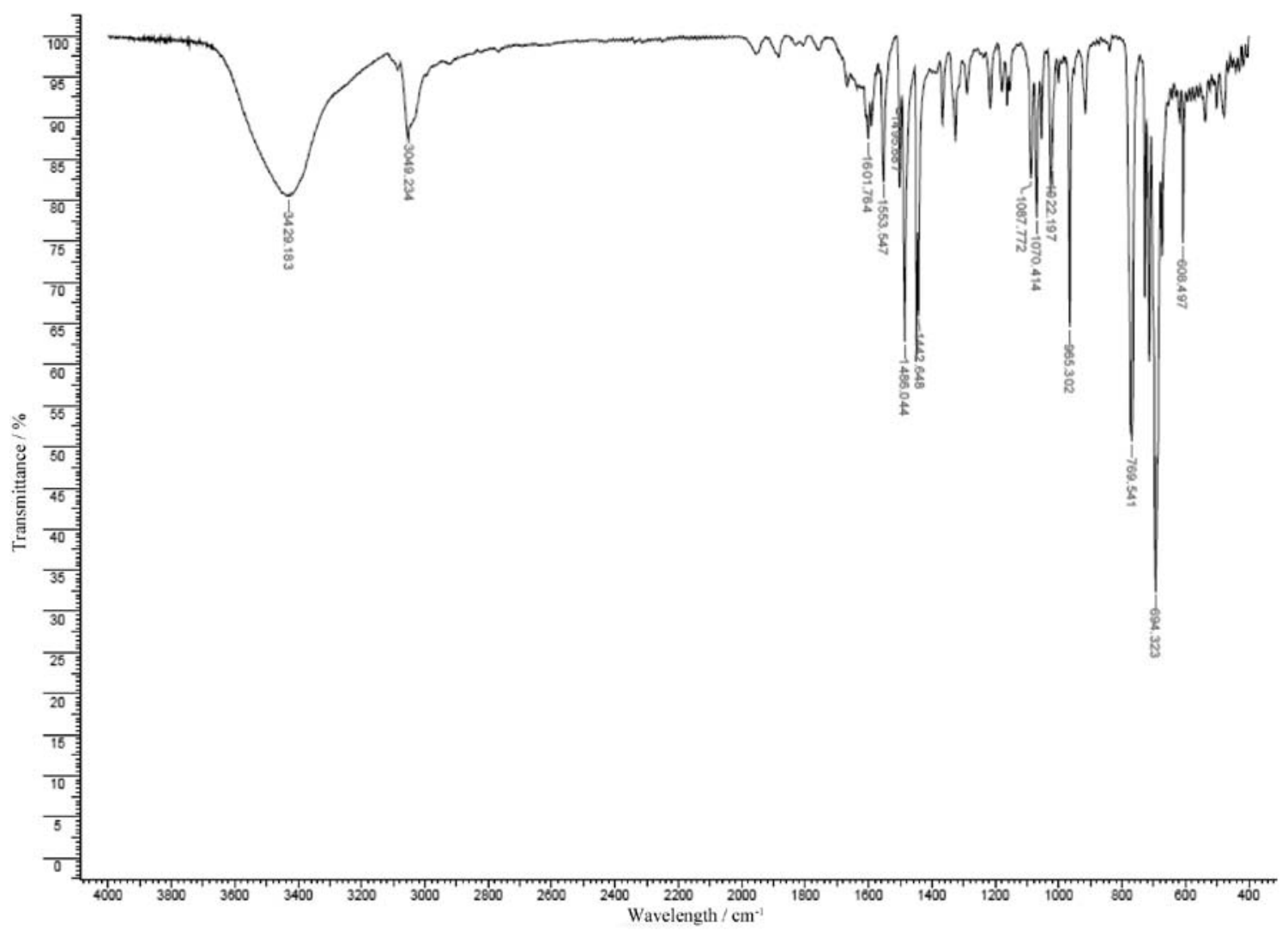

Figure S72. IR spectrum (KBr) of compound 2,4,5-triphenyl-1,3-oxazole (10a).

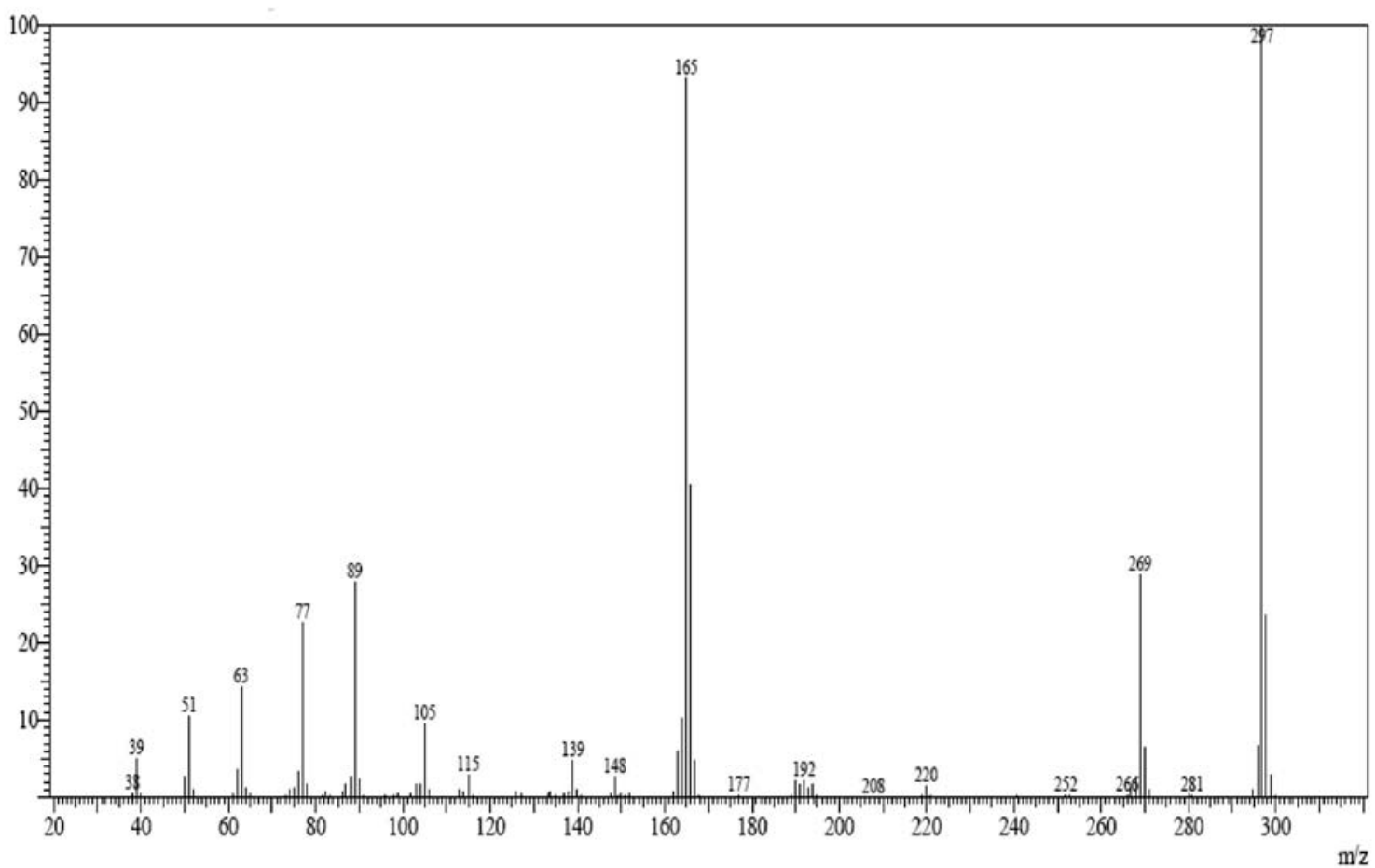

Figure S73. Mass spectrum (70 eV) of compound 2,4,5-triphenyl-1,3-oxazole (10a). 


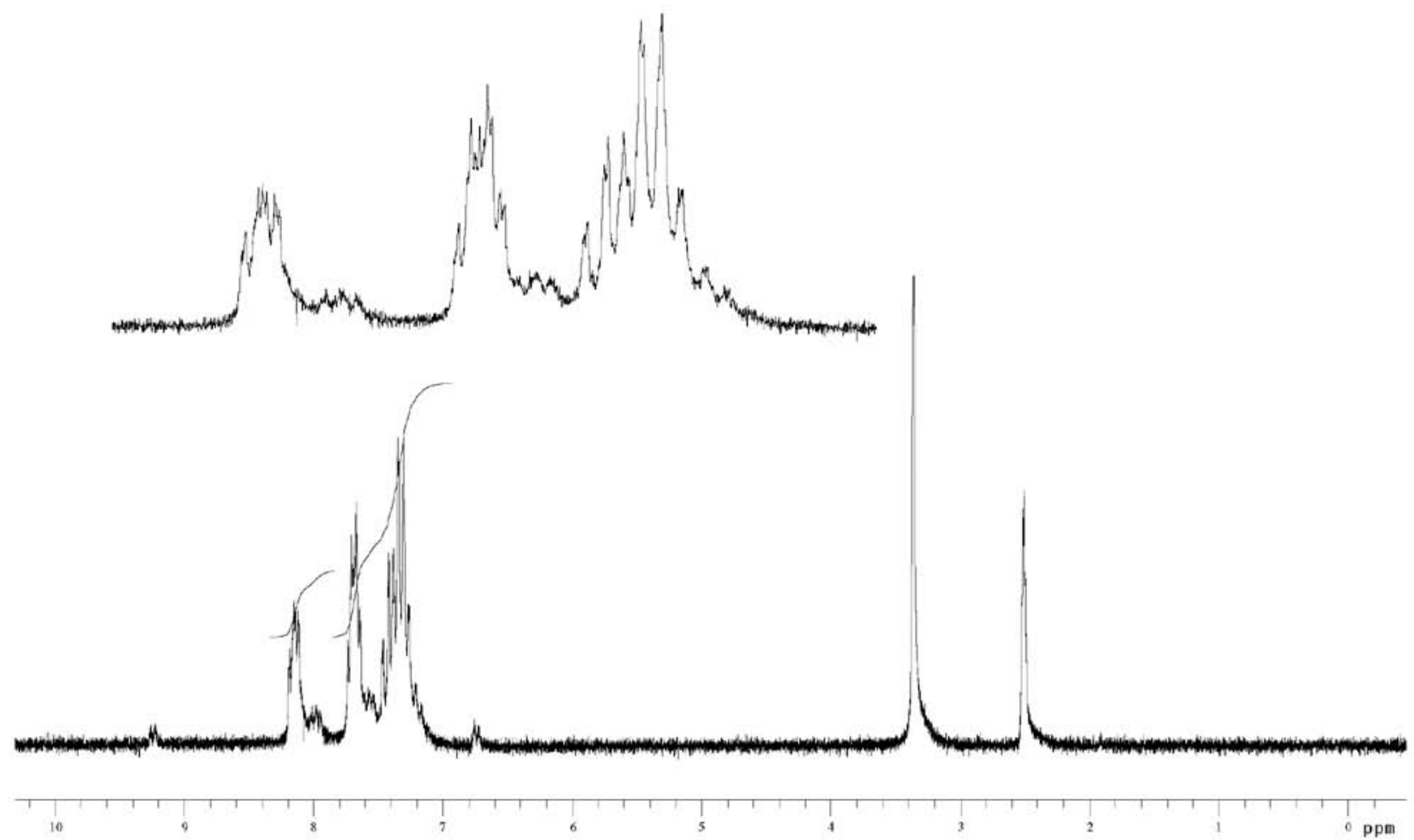

Figure S74. ${ }^{1} \mathrm{H}$ NMR spectrum (200 MHz, DMSO- $d_{6}$ ) of compound 2,4,5-tris(4-fluorophenyl)-1,3-oxazole (10b).

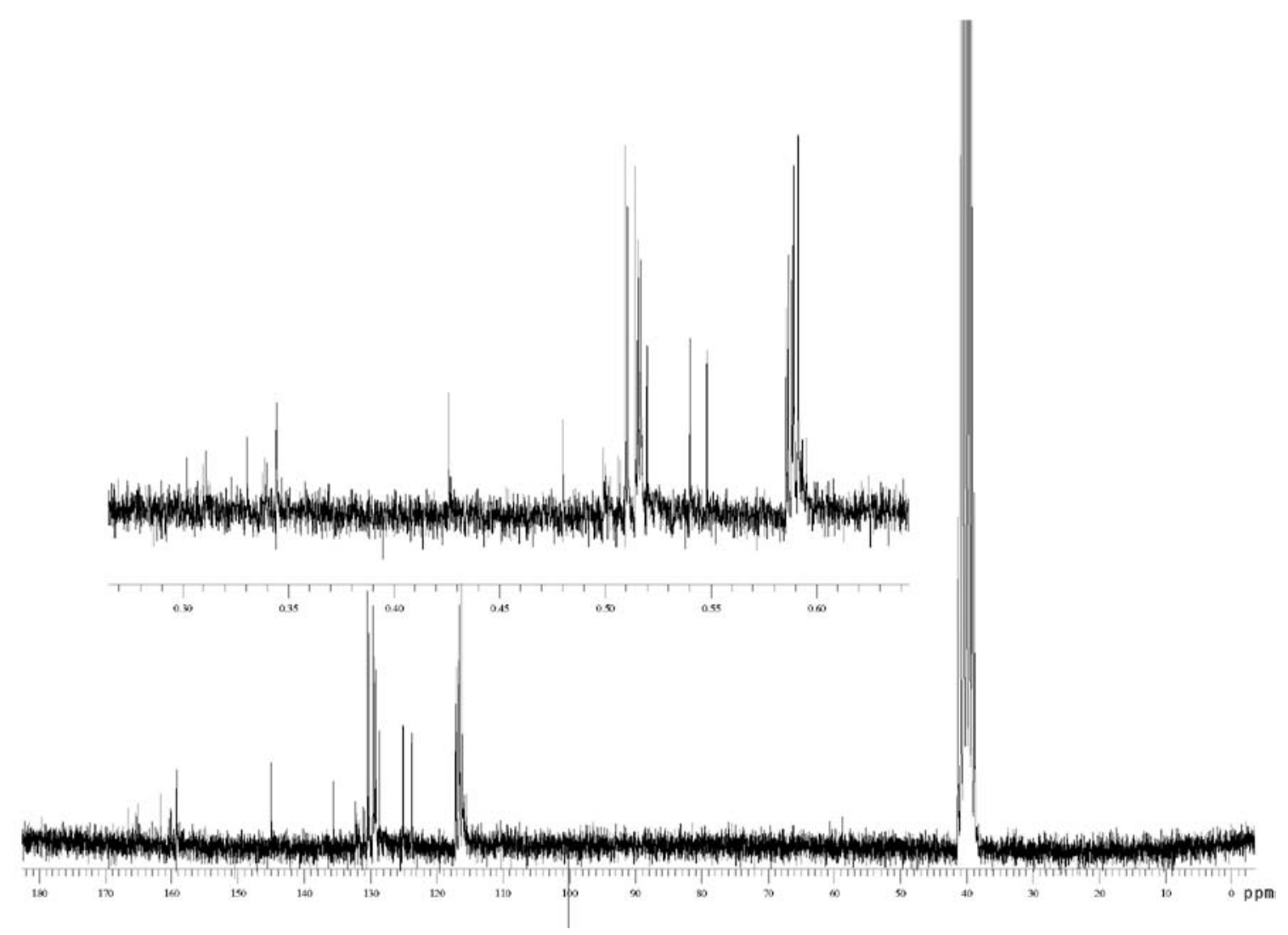

Figure S75. ${ }^{13} \mathrm{C}$ NMR spectrum (50 MHz, DMSO- $d_{6}$ ) of compound 2,4,5-tris(4-fluorophenyl)-1,3-oxazole (10b). 


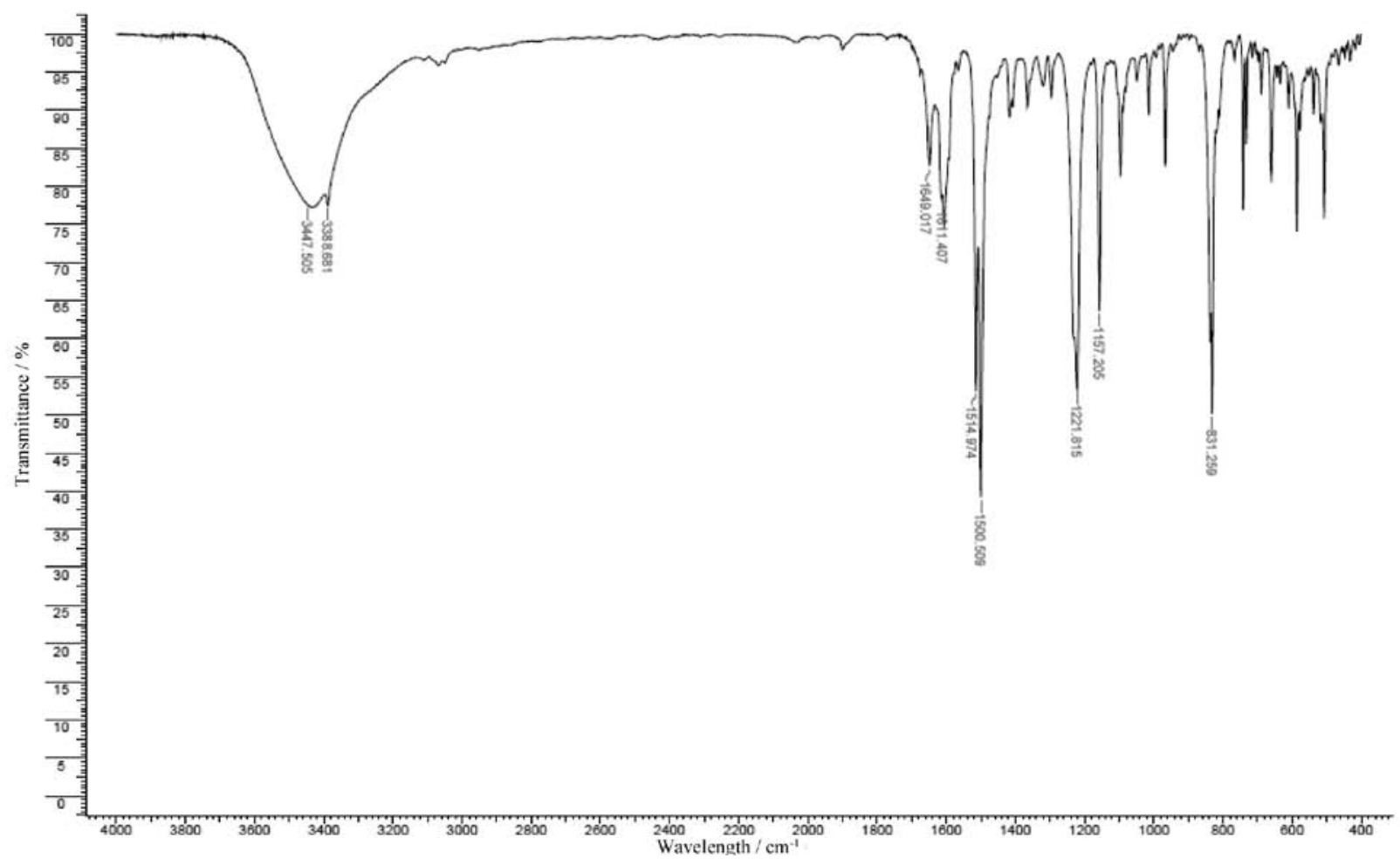

Figure S76. IR spectrum (KBr) of compound 2,4,5-tris(4-fluorophenyl)-1,3-oxazole (10b).

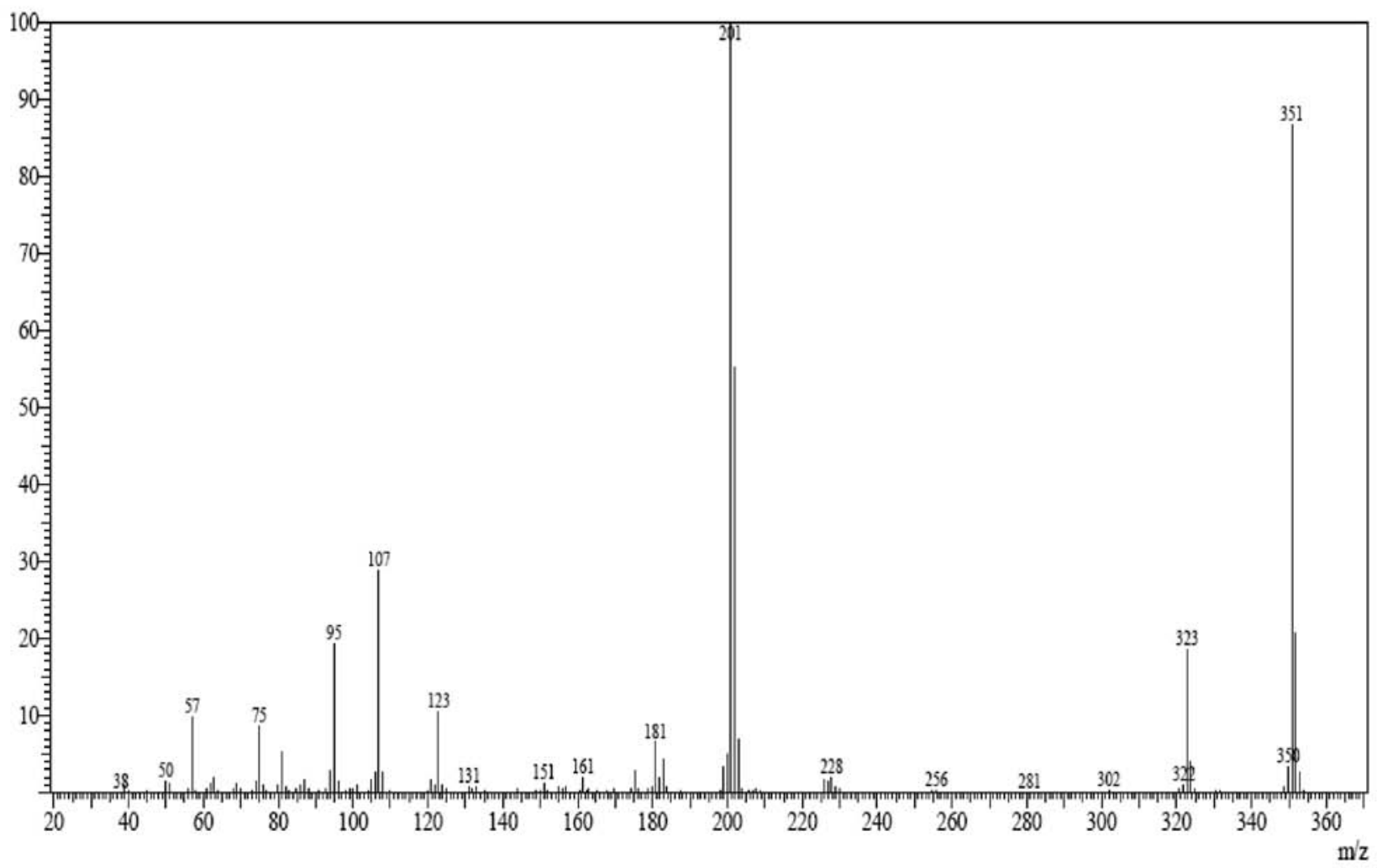

Figure S77. Mass spectrum (70 eV) of compound 2,4,5-tris(4-fluorophenyl)-1,3-oxazole (10b). 


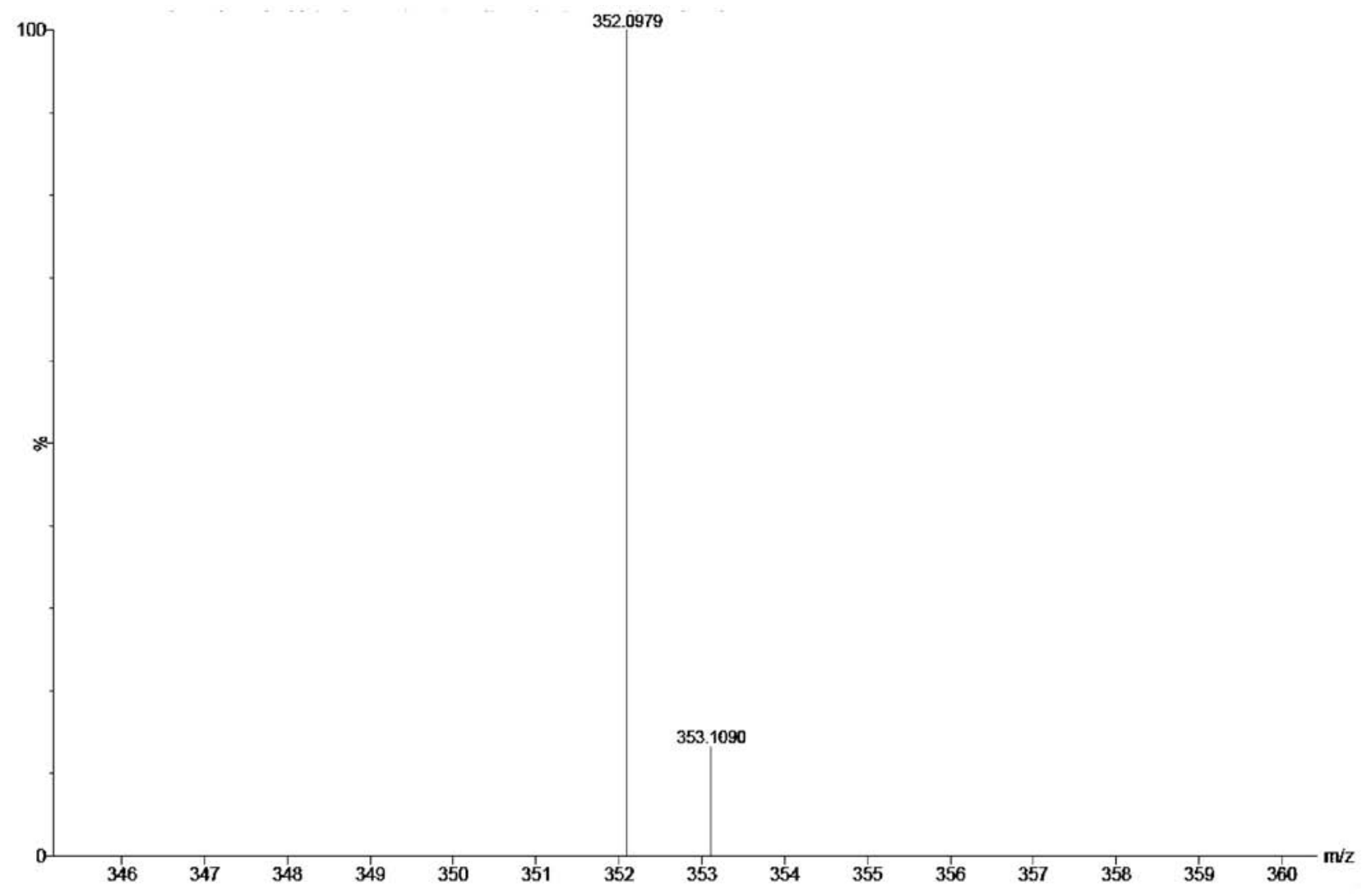

Figure S78. HRMS (ESI +) of compound 2,4,5-tris(4-fluorophenyl)-1,3-oxazole (10b). 